GABRIEL SALLES BARBÉRIO

\title{
Identificação do biomarcador NS1 na saliva como diagnóstico da dengue
}

\begin{abstract}
Dissertação apresentada à Faculdade de Odontologia de Bauru da Universidade de São Paulo para obtenção do título de Mestre em Ciências no Programa de Ciências Odontológicas Aplicadas, na área de concentração Odontopediatria.

Orientadora: Profa ${ }^{\text {Dra }}$. Maria Aparecida de Andrade Moreira Machado
\end{abstract}

Versão Corrigida

BAURU

2013 


\begin{tabular}{|c|c|}
\hline \multirow[t]{3}{*}{ B233i } & $\begin{array}{l}\text { Barbério, Gabriel Salles } \\
\quad \text { Identificação do biomarcador NS1 na saliva } \\
\text { como diagnóstico da dengue / Gabriel Salles } \\
\text { Barbério. - Bauru, } 2013 \text {. } \\
\quad 113 \text { p. : il. ; } 31 \mathrm{~cm} \text {. }\end{array}$ \\
\hline & $\begin{array}{l}\text { Dissertação (Mestrado) - Faculdade de } \\
\text { Odontologia de Bauru. Universidade de São Paulo }\end{array}$ \\
\hline & $\begin{array}{l}\text { Orientadora: Profa. Dra. Maria Aparecida de } \\
\text { Andrade Moreira Machado }\end{array}$ \\
\hline
\end{tabular}

Nota: A versão original desta dissertação encontra-se disponível no Serviço de Biblioteca e Documentação da Faculdade de Odontologia de Bauru - FOB/USP.

Autorizo, exclusivamente para fins acadêmicos e científicos, a
reprodução total ou parcial desta dissertação/tese, por processos
fotocopiadores e outros meios eletrônicos.
Assinatura: Banbéiog
Data: $04 / 08 / 2013$

Comitê de Ética da FOB-USP Protocolo $\mathrm{n}^{\circ}: 119 / 2011$

Data: 01/12/2011 


\section{DEDICATÓRIA}

Dedico este trabalho aos meus pais Rolando (in memoriam) e Ana Rita, com todo meu amor e gratidão, por tudo que fizeram por mim ao longo de minha vida. Desejo poder ter sido merecedor do esforço dedicado por vocês em todos os aspectos, especialmente quanto à minha formação.

A meus avós, Paulina e Lourenço, especialmente, que me deram todo o suporte necessário.

A minha namorada, Ana Zingra, que esteve ao meu lado nesta jornada de estudante sem fim.

A todas as vítimas da dengue principalmente as que morreram pelo descaso ao banalizar uma doença que continua flagelando milhares de famílias. Que este estudo, grão de areia buscando reduzir o oceano de descaso sobre o assunto, possa ajudar a oferecer-lhes um futuro melhor.

A eles, de coração, dedico este trabalho. 


\section{AGRADECIMENTOS}

Em certa feita disse Guimarães Rosa que "mestre não é quem ensina, mas quem de repente aprende". E o processo de aprendizado não se constitui sozinho. Sendo assim ao concluir esta dissertação seria hipocrisia dizer que esta dissertação é minha. Esta dissertação é o resultado do esforço comum de diversas pessoas e algumas instituições. Reconhecer e agradecer a contribuição de cada um, independentemente do tamanho, fazme ainda mais feliz, pois assim percebo que não caminho só, desta forma, sou grato:

A todos os que de alguma forma contribuíram para a realização deste sonho, meu eterno agradecimento.

A minha orientadora, Profa. Dra. Maria Aparecida de Andrade Moreira Machado, um exemplo profissional a ser seguido, exemplo de verdadeiro mestre que se destaca por sua preocupação na formação de seus alunos. Agradeço por seu precioso tempo dedicado a minha formação, por acreditar e confiar em meu potencial, pela amizade, pelo carinho e apoio. Ser orientado pela Profa. Cidinha é um privilégio de poucos e sinto-me honrado pela oportunidade. Deixo registrado aqui o meu singelo e sincero muito obrigado.

Ao Prof. Dr. Walter Luiz Siqueira, por ser o mentor deste trabalho e por direcionar esta linha de pesquisa tão promissora.

Aos docentes da Disciplina de Odontopediatria: Salete Moura Bonifácio da Silva, que me fez entender a importância do manejo em odontopediatria; Thais Marchini de Oliveira, por me mostrar que existe vida além da carreira profissional, por sempre me apoiar nos momentos de clínica e me despertou a paixão por traumatismo

dentário; Daniela Rios, que despertou em mim a vontade de me dedicar para alcançar um objetivo e como fazer um bom diagnóstico de cárie; Ruy César Camargo Abdo que me auxiliou na minha primeira pulpectomia e tornou-a fácil e descomplicada e ao José Eduardo de Oliveira Lima, que me despertou o senso crítico para os dogmas da odontologia. A todos vocês obrigado pela transmissão de conhecimentos e ensinamentos durante o curso de pós-graduação, pela disponibilidade e pela contribuição a minha formação pessoal e profissional.

A minha namorada,

Ana Cristina de Godoi Zingra, por todo amor e carinho nos momentos difíceis e pela paciência. São insuficientes minhas palavras para agradecê-la, pois foi quem efetivamente me apoiou em todas as etapas dessa caminhada do início ao fim.

Aos pais da minha namorada, Sr. Luiz e D. Olga, que me acolheram em suas casas com muito carinho nessa jornada sem fim.

À Universidade de São Paulo, na pessoa do Magnífico Reitor Prof. Dr. João Grandino Rodas, pela infraestrutura e apoio concedido. À Diretoria da Faculdade de Odontologia de Bauru, na pessoa do

Prof. Dr. José Carlos Pereira, Valéria e Graciane (Teca), e à Comissão de Pós-Graduação na pessoa do Prof. Dr. Paulo Conti, pelo apoio recebido a todo momento. 
por me receberem mesmo com tantos afazeres e por valorizarem a pesquisa da FOB.

Ao Hospital Estadual de Bauru, na pessoal do Dr. Luiz Eduardo Naresse e da médica infectologista $D r^{a}$. Valéria Drumond Nagem Aragão pela disponibilidade, confiança, acolhimento e apoio prestados.

À Unidade de Pronto Atendimento - Vila Ipiranga na pessoa da Rita, Laudicéia, Juliana e Edilaine pela enorme ajuda e disposição.

Aos Chefes de Departamento,

Prof. Dr. Guilherme Janson e Prof. Dr. José Roberto de Magalhães Bastos, pela oportunidade, receptividade e disponibilidade de seus docentes e funcionários.

Aos funcionários queridos, “D. Lia”, Lilian, Estela, Evandro, André, Kaká e Alexandre por toda ajuda, suporte e disponibilidade. A vocês agradeço principalmente pela amizade e carinho sincero.

À Secretaria de Pós-Graduação da FOB-USP, Meg, Letícia, Leila e Fátima, por resolverem com alegria tantas questões burocráticas.

Ao Comitê de Ética em Pesquisa da Universidade de São Paulo, na pessoa da Maristela, e do Hospital Estadual de Bauru. por viabilizarem com muita solicitude todas as atividades.

Meus singelos agradecimentos a todos os professores da Faculdade de Odontologia de Bauru, especialmente aos professores Paulo Sérgio da Silva Santos, Flávio Augusto Cardoso de Faria, Ana Paula Campanneli, Heitor Marques Honório.

À equipe do laboratório de Farmacologia da Faculdade de Odontologia de Bauru, em especial ao Thiago e ao Prof. Dr. Carlos Ferreira dos Santos, por todo auxílio laboratorial sem o qual não teria realizado esse trabalho.

A todos os funcionários da Biblioteca da FOB, em especial à Cybelle, que diariamente nos auxiliam na constante busca do conhecimento.

A todos os meus amigos da convivência sempre alegre e amistosa, especialmente: Sol, Nadião, Pri, Vivi, Catarina, Pitty, Juliana, Adriana, Carla, Natalino e Akio, Juliherme, Lucas Mendes, Raro, Jack, Felícia, Doril, Carron, Mariana dos Santos, Mari Dentista, Mari Design, André, Luciano, Susy, Sileide, Aloísio, Kim, Alan e todos cujos nomes seria impossível citar, por multiplicarem alegrias e dividirem tristezas.

Ao CNPq, pela concessão da bolsa.

À FAPESP, pelo auxílio regular e concessão da bolsa. 
"Toda glória deriva da ousadia de começar." Eugene F. Ware, advogado.

"O covarde nunca começa, o fracassado nunca termina e o vencedor nunca desiste." Normam Vicent Peale, escritor.

"O conhecimento vem do instrutor; a sabedoria do seu interior." Bruce Lee, ator.

"A confiança em si próprio é o primeiro segredo do êxito." Ralph Waldo Emerson, filósofo. 


\section{RESUMO}

\section{BARBÉRIO, G. S. Identificação do biomarcador NS1 na saliva como diagnóstico}

de dengue. 2013. 99 f. Dissertação (Mestrado) - Faculdade de Odontologia de Bauru, Universidade de São Paulo, Bauru, 2013.

Muitas ferramentas de diagnóstico da dengue tornaram-se disponíveis, porém requerem coleta de sangue como amostra para análise. Um método não invasivo de confirmar a infecção por dengue seria de importância considerável para os estudos clínicos e epidemiológicos. Testes de saliva podem encorajar os pacientes a serem mais receptivos para o diagnóstico da dengue. Possíveis problemas com o uso de sangue incluem a exigência de consentimento e a cooperação do paciente. Em muitos casos, flebotomia em indivíduos com fobia de agulhas, portadores de deficiências e discrasias sanguíneas e, especialmente em bebês e crianças, ou ainda devido a razões sociais, religiosas, à necessidade de um enfermeiro treinado e à necessidade de se separar o soro do plasma antes do teste. Objetivo deste trabalho foi identificar RNA viral em amostras de saliva de pacientes infectados com dengue durante o período febril; avaliar o teste rápido para identificar NS1 em amostra de saliva; identificar a presença de NS1 em amostras de saliva por meio do teste ELISA. Foram coletas amostras de saliva de pacientes durante o período febril com e sem dengue. Todos diagnósticos foram confirmados por exame de sangue para IgM/lgG. Foi feito o teste da Reação em Cadeia da Polimerase em Tempo Real em 10 amostras de pacientes com dengue. Em 44 amostras foram testados as tiras de diagnóstico rápido da dengue e ao teste ELISA NS1, para a detecção da proteína NS1. Esse estudo ressaltou a importância da busca pelo diagnóstico laboratorial rápido, prático e financeiramente acessível de doenças febris agudas com sintomas inespecíficos, principalmente em áreas de ocorrência de dengue. Nesse estudo foi encontrada alta especificidade (94\%) e média sensibilidade $(73 \%)$ nos resultados da identificação da proteína NS1 nas amostras de saliva em estágios precoces da infecção por dengue. Esse método, se aprimorado para saliva, poderá ter resultados ainda melhores, por isso mais estudos são necessários.

Palavras-chave: Dengue. Saliva. Diagnóstico. 


\begin{abstract}
BARBÉRIO, G. S. NS1 biomarker identification on saliva for dengue diagnosis. 2013. 99 f. Dissertação (Mestrado) - Faculdade de Odontologia de Bauru, Universidade de São Paulo, Bauru, 2013.
\end{abstract}

This study brings a literature review about the current dengue status worldwide and in Brazil followed by a systematic review that highlights the dengue diagnosis through saliva. A prospective study was also made, which evaluated the dengue virus infection diagnosis accuracy through the NS1 antigen detection in saliva samples using ELISA assays. The NS1-ELISA results in saliva were compared to the IgM-ELISA and IgG-ELISA serology. A total of 44 saliva samples were obtained from November 2012 to February 2013. The results showed that de NS1ELISA presented a sensibility of 0.73 , specificity of 0.94 , Positive Predictive Value of 0.95, Negative Predictive Value of 0.70, Positive Likelihood Ratio of 13.15, Negative Likelihood Ratio of 0.28 . Having these findings in mind, it is possible to suggest that the NS1 detection in saliva may be an important diagnostic tool in special cases, such as people that fear needles, with blood dyscrasias, babies, children, as well as to quickly monitor epidemics and their dissemination.

Key words: Saliva. Dengue. Diagnostic. 


\section{LISTA DE ILUSTRAÇÕES}

FIGURA 1 - ÁREAS (VERMELHO) EM QUE A DENGUE REPRESENTA UM SÉRIO PROBLEMA DE SAÚDE EM 2010.. 20

FIGURA 2 - INFESTAÇÃO POR AEDES AEGYPTI NO ESTADO DE SÃO PAULO EM 1985...............................22

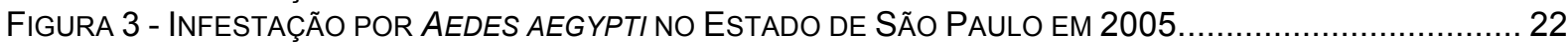

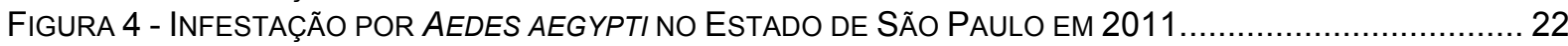

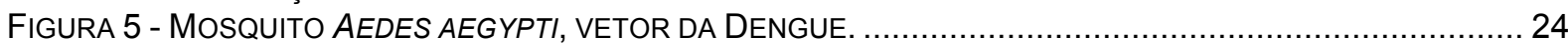

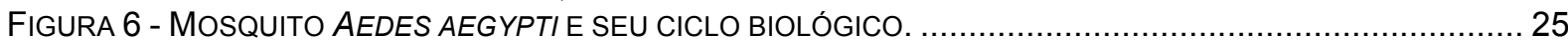

FIGURA 7 - DESENHO ESQUEMÁTICO DO VÍRUS DENGUE MOSTRANDO SUAS PROTEÍNAS ESTRUTURAIS. ........26

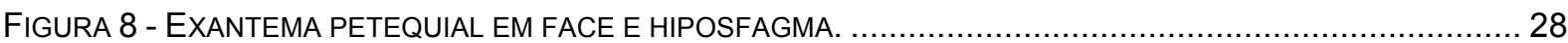

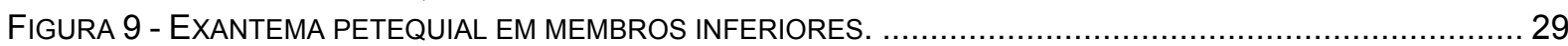

FIGURA 10 - GRÁFICO MOSTRANDO OS NIVVEIS DE NS1, IGM E IGG DE ACORDO COM O PERÍODO FEBRIL EM

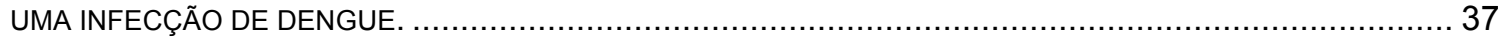

FIGURA 11 - DESENHO ESQUEMÁTICO DOS TRABALHOS INCLUÍDOS NA REVISÃO SISTEMÁTICA......................39

FIGURA 12 - CRITÉRIOS ORIGINAIS DA FERRAMENTA DE AVALIAÇÃO (QUADAS) DOS ARTIGOS INCLUÍDOS NA

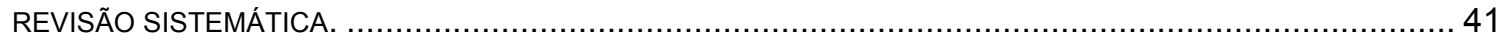

FIGURA 13 - CURVA ROC DOS TRABALHOS UTILIZANDO SALIVA E IGM PARA DIAGNÓSTICO DA DENGUE.......47

FIGURA 14 - CURVA ROC DOS TRABALHOS UTILIZANDO SALIVA E IGG PARA DIAGNÓSTICO DA DENGUE. .......47

FIGURA 15 - CURVA ROC DOS TRABALHOS UTILIZANDO SALIVA E IGA PARA DIAGNÓSTICO DA DENGUE........47

FIGURA 16 - FOTO DO PROCEDIMENTO DE COLETA NA REALIZAÇÃO DO ESTUDO PILOTO...........................57

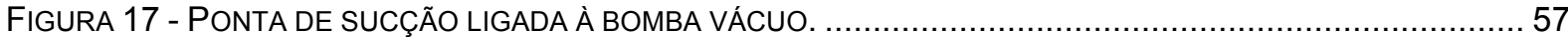

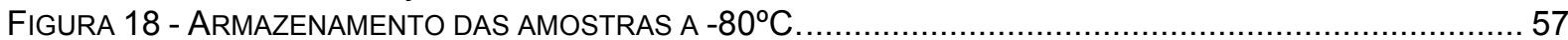

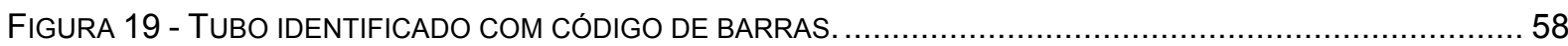

FIGURA 20 - BANCO DE DADOS COM ALGUNS DADOS DAS AMOSTRAS COLETADAS. ..................................58

FIGURA 21 - PANORÂMA GERAL DE TODO O PROTOCOLO PARA REALIZAÇÃO DO PCR-RT DEMOSTRANDO COMO É TRABALHOSO, DEMORADO E REQUER PRÁTICA LABORATORIAL PARA REALIZA-LO. .........................59

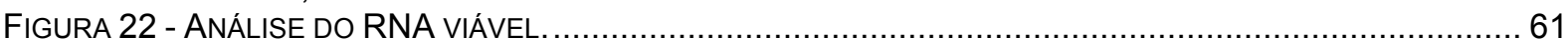

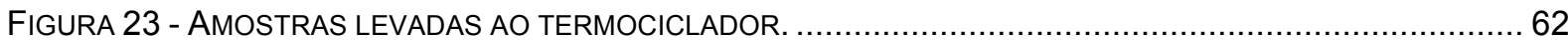

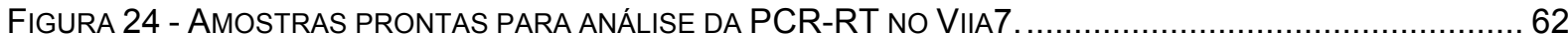

FIGURA 25 - ETAPAS PARA REALIZAÇÃO DO TESTE IMUNOCROMATOGRÁFICO NS1 AG STIP......................63

FIGURA 26 - FIGURA ILUSTRATIVA DAS TIRAS UTILIZADAS NO TESTE IMUNOCROMATOGRÁFICO NS1 E SEUS

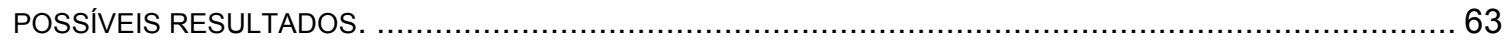

FIGURA 27 - TIRA PARA DIAGNÓSTICO DE DENGUE SENDO UTILIZADO EM AMOSTRA DE SALIVA $\ldots \ldots \ldots \ldots \ldots \ldots . . . . . . .64$

FIGURA 28 - PROCESSAMENTO DAS AMOSTRAS DURANTE O ELISA PARA NS1 ..................................6 65

FIGURA 29 - IMAGEM DA TELA DE RESULTADO DO PCR-RT MOSTRANDO QUE NÃO HOUVE AMPLIFICAÇÃO EM

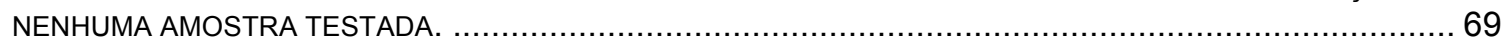

FIGURA 30 - IMAGEM MOSTRANDO QUE NÃO HÁ RESULTADO QUANDO É COLOCADA TIRA EM AMOSTRAS DE SALIVA, NEM A LINHA TESTE NEM A LINHA CONTROLE FICAM PIGMENTADAS. 


\section{LISTA DE TABELAS}

TABELA 1 - CARACTERÍSTICA DOS ARTIGOS INCLUIDOS NA REVISÃO SISTEMÁTICA 40

TABELA 2 - AVALIAÇÃO DO QUADAS PARA TODOS OS ARTIGOS INCLUÍDOS NESSA REVISÃO PARA IDENTIFICAR O RISCO DE VIÉS.

TABELA 3 - DESCRIÇÃO DOS RESULTADOS ENCONTRADOS NA UTILIZAÇÃO DE IGM PARA DIAGNÓSTICO DA DENGUE NA SALIVA.

TABELA 4 - DESCRIÇÃO DOS RESULTADOS ENCONTRADOS PARA UTILIZAÇÃO DE IGG PARA DIAGNÓSTICO DA DENGUE NA SALIVA.

TABELA 5 - DESCRIÇÃO DOS RESULTADOS ENCONTRADOS PARA UTILIZAÇÃO DE IGA PARA DIAGNÓSTICO DA DENGUE NA SALIVA.

TABELA 6 - DESCRIÇÃO DOS RESULTADOS ENCONTRADOS PARA UTILIZAÇÃO DE NS1 PARA DIAGNÓSTICO DA DENGUE NA SALIVA

TABELA 7 - META-ANÁLISE DA SENSIBILIDADE E ESPECIFICIDADE DOS ESTUDOS INCLUÍDOS.......................... 48

TABELA 8 - EFETIVIDADE DA IDENTIFICAÇÃO DA NS1 DE ACORDO COM O DIA DE INÍCIO DA FEBRE................. 71

TABELA 9 - COMPARAÇÃO DA EFETIVIDADE DOS DIAGNÓSTICOS DURANTE A EPIDEMIA E NO PERÍODO ENTRE AS EPIDEMIAS. 


\section{SUMÁRIO}

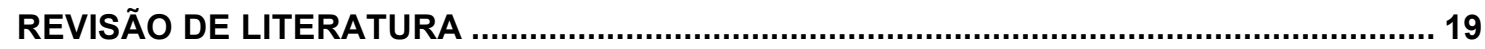

2.1 ORIGEM

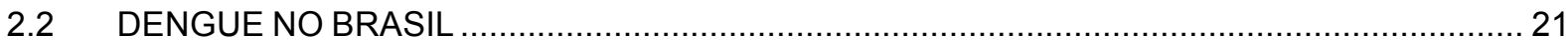

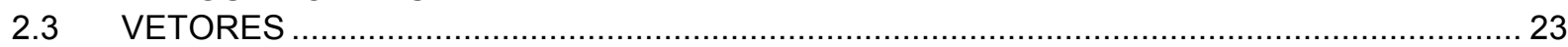

2.4 O VÍRUS

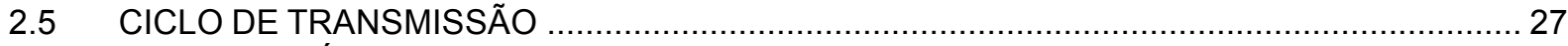

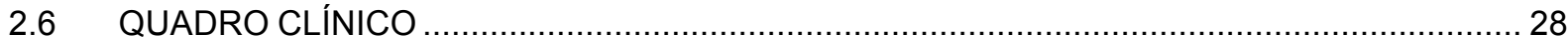

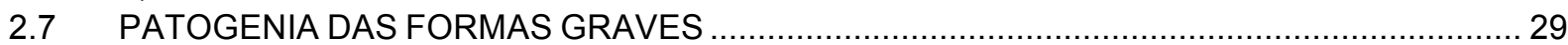

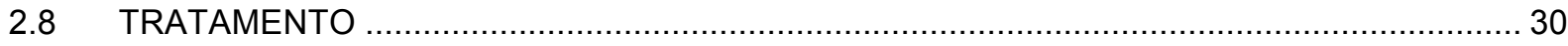

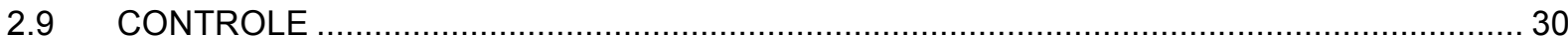

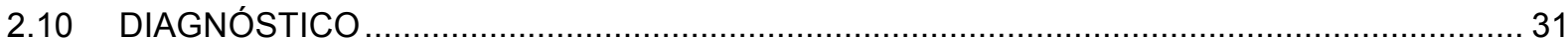

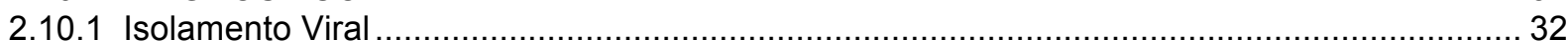

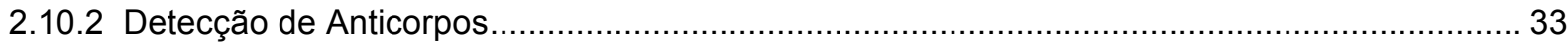

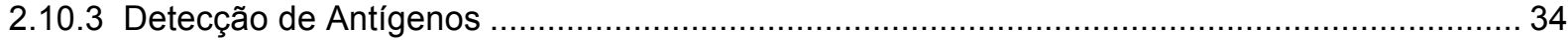

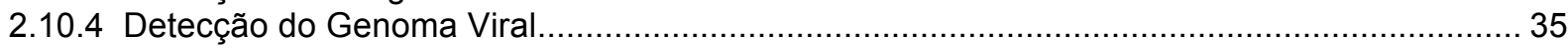

2.11 REVISÃO SISTEMÁTICA DA LITERATURA - DIAGNÓSTICO DA DENGUE ATRAVÉS DA SALIVA .................. 36

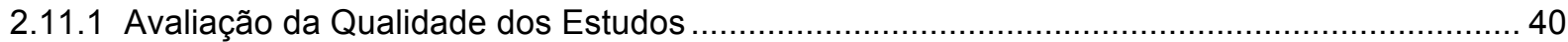

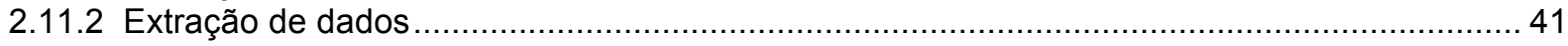

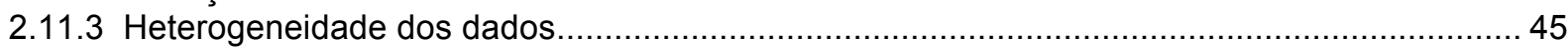

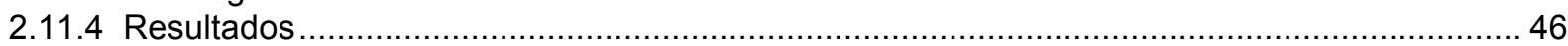

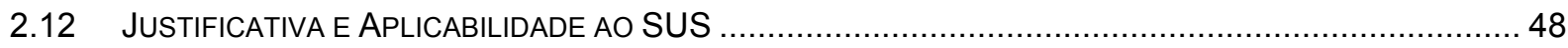

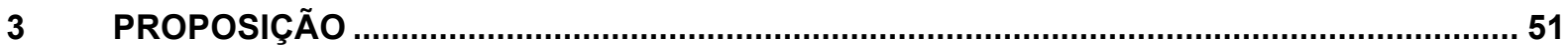

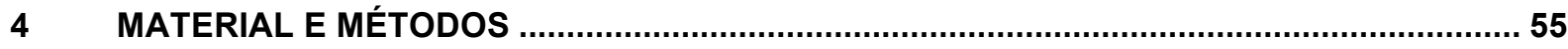

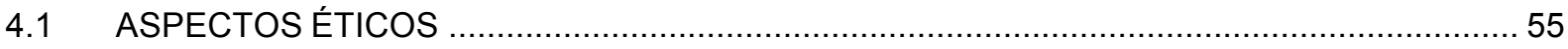

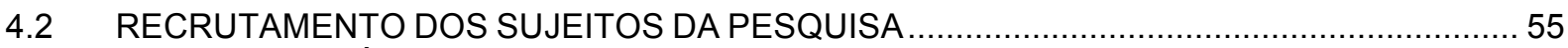

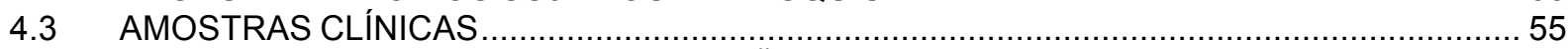

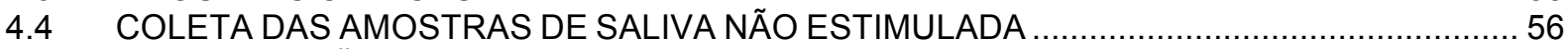

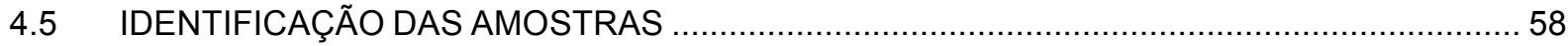

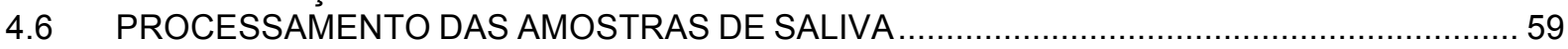

4.6.1 Reação em Cadeia da Polimerase em Tempo Real (PCR-RT) …....................................... 59

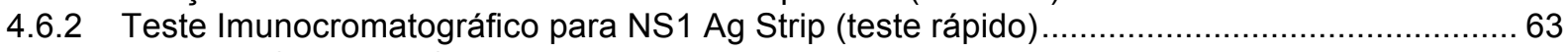

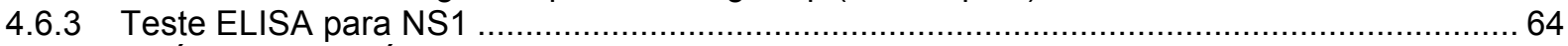

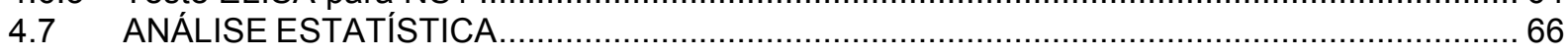

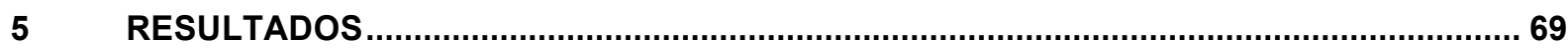

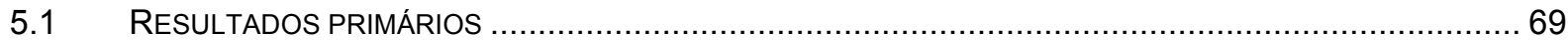

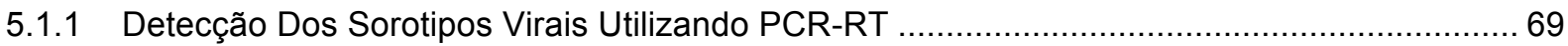

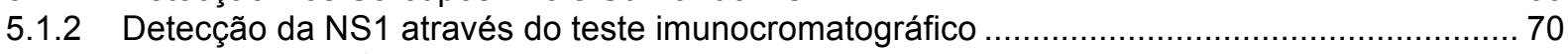

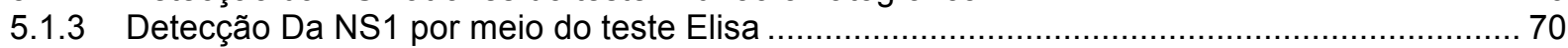

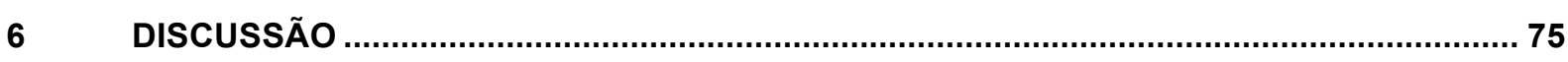

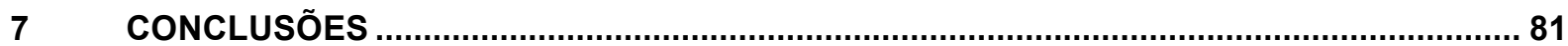





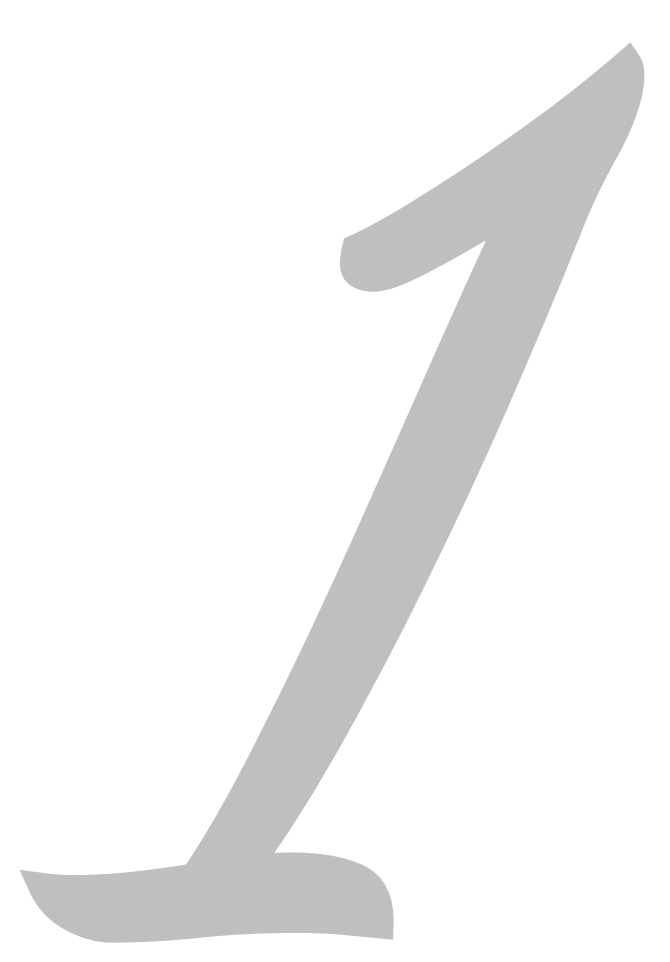

\section{Tntrodução}

"Uma longa viagem começa com um único passo"

Lao-Tse 





\section{INTRODUÇÃO}

O vírus da Dengue faz parte da família de vírus chamada Flavivirus, que são vírus transmitidos por artrópodos, no caso da Dengue, transmitida por mosquitos do gênero Aedes, especialmente pelo Aedes aegypti. Esse vírus possui quatro sorotipos diferentes, classificados em 1, 2, 3 e 4, sendo que qualquer um dos 4 tipos pode causar Dengue Clássico, Dengue com Complicações, Febre Hemorrágica da Dengue ou Síndrome do Choque da Dengue. Nos últimos 25 anos houve um ressurgimento da Dengue em vários países. Dois bilhões e meio de pessoas vivem em área de risco para contrair Dengue no mundo e, anualmente, ocorrem entre 50 e 100 milhões de infecções, sendo 500.000 casos de febre hemorrágica da Dengue e 21.000 óbitos, acometendo principalmente crianças. As crianças menores de 15 anos de idade representam $90 \%$ dos casos de Dengue grave que tem sido uma das principais causas de internação e morte infantil em vários países. Entre 2000 e 2005, o Brasil foi o país com maior número de casos de Dengue em todo o mundo, com mais de três milhões de casos relatados, esse número representa $61 \%$ de todos os casos diagnosticados no mundo. Em 2009, foram registrados 393.583 casos no Brasil. Em 2010, apenas no Estado de São Paulo, um dos mais desenvolvidos do país, foram confirmados 191.193 casos. Ainda nesse Estado, no período de Janeiro a Maio de 2013, foram diagnosticados 1.778 casos, sendo 1.773 desses na cidade de Bauru - SP (CVE, 2013).

Não existe apenas um único, mas sim quatro tipos de vírus da dengue, os quais são transmitidos, na maioria das vezes, em países tropicais por todo o mundo. Os quatro tipos de vírus podem causar doenças que podem ser brandas ou muito agressivas (HALSTEAD, 2007). Aproximadamente 2,5 bilhões de pessoas estão em áreas de risco à dengue. Cinquenta milhões de casos ocorrem por ano e 500.000 deles são do tipo hemorrágica, que é uma manifestação grave da doença causada pelo vírus dengue (MACKENZIE; GUBLER; PETERSEN, 2004). Por isso a dengue é classificada como uma endemia, ou seja, uma doença infecciosa que ocorre em um determinado local, sobre uma determinada população e que pode ser localizada geograficamente. Por exemplo, a febre amarela que somente ocorre na faixa da floresta Amazônica ou a dengue, que somente ocorre em regiões cujo clima favorece o surgimento do mosquito Aedes aegypti. 
Para controlar efetivamente a transmissão da dengue, é necessário identificar o local do criadouro do mosquito transmissor, para isso, é necessário o diagnóstico preciso da doença seguida da visita das equipes de controle de vetores nos possíveis locais de infestação para eliminar os criadouros do mosquito. Assim, um diagnóstico correto e rápido é essencial. No entanto, o diagnóstico correto não é fácil, pois, os sintomas causados durante a infecção por dengue não são específicos: febre, cefaleia, mialgia, artralgia, exantema e, algumas vezes, discrasias sanguíneas, são rotineiramente confundidos com muitas outras doenças (GUZMAN; KOURI, 1996). Assim, existe uma necessidade de buscar melhorias para o método de diagnóstico laboratorial para a dengue, que, atualmente, é feito através por um método invasivo que é pela análise de sangue (BROWN et al., 1994). A necessidade de coleta de sangue em todos os casos de suspeita de infecção por dengue dificulta a detecção precoce dos casos e, assim, atrasa os esforços de controle do vetor. A coleta de sangue é complexa, cara e limita a amplitude de investigação laboratorial, devido à falta de colaboração dos pacientes, principalmente quando se tratam de crianças, bebês, portadores de deficiências, pessoas com discrasias sanguíneas e pessoas com medo de flebotomia (BROWN et al., 1994).

Algumas doenças, como o câncer bucal (JOU et al., 2010), fibromialgia (BAZZICHI et al., 2009), síndrome de Sjögren (HU et al., 2010), hepatite (PARRY et al., 1989) e neurocisticercose (FELDMAN et al., 1990) já tem marcadores salivares identificados. Há também muitos anticorpos que foram relatados por serem confiáveis para o diagnóstico de algumas infecções, entre elas AIDS (FRERICHS; ESKES; HTOON, 1994), leptospirose (DA SILVA et al., 1992), sarampo (FRIEDMAN; PHILLIP; DAGAN, 1989), hepatite A e B (PARRY et al., 1989), rubéola (DE AZEVEDO NETO et al., 1995) e parvovirus. Sendo assim, estudar biomarcadores salivares relacionados ao vírus da dengue é uma estratégia que deve ser incentivada. O monitoramento epidemiológico preciso da dengue necessita de confirmação laboratorial, desta forma, na ausência de um fármaco ou vacina para infecções de dengue, os biomarcadores salivares podem classificar um sujeito como positivo ou negativo para infecções de dengue. Essa pode ser uma estratégia de apoio para o tratamento e melhoria da gestão clínica de saúde. Portanto, o desenvolvimento de um teste laboratorial usando saliva que possa ser usado para diagnosticar a dengue, será oportuno e importante na trajetória de controle dessa doença. 


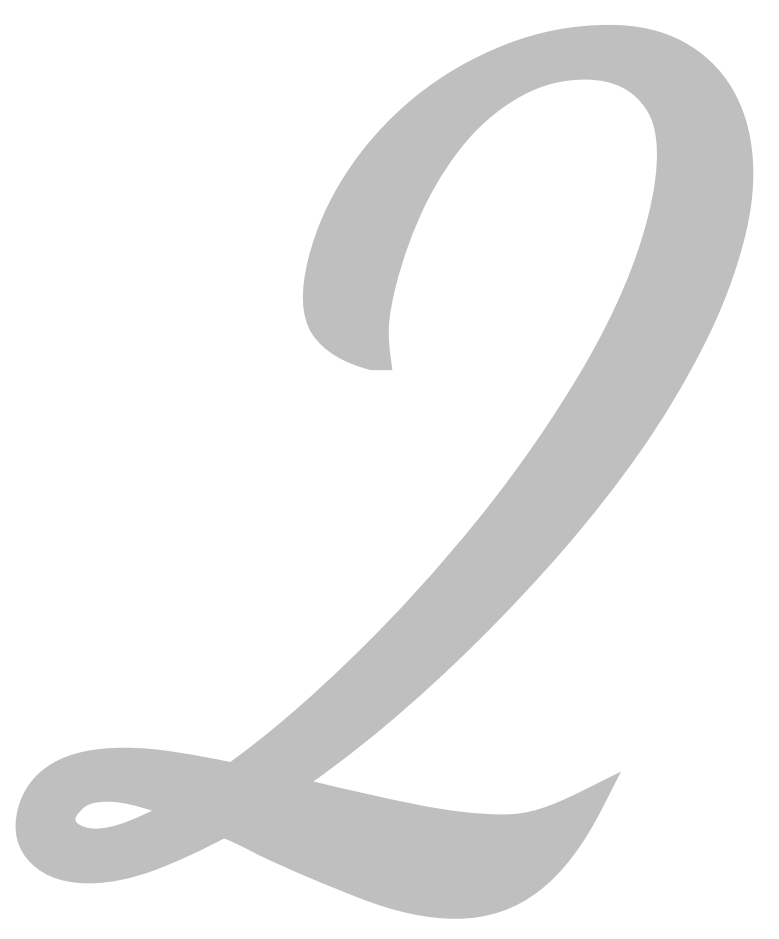

\section{Revisão de} Literatura

"A experiência nos mostra que o sucesso é devido menos à habilidade que ao zelo. O vencedor é aquele que se entrega inteiro à busca, de corpo e alma." 



\section{REVISÃO DE LITERATURA}

\subsection{ORIGEM}

A primeira descrição de sua forma epidêmica foi descrita em 1780 nos Estados Unidos, quando foi chamada de "febre quebra ossos". Porém os possíveis relatos mais antigos da dengue estão em enciclopédias chinesas de 265 a 420 D.C e também do século XVII no Panamá, Indonésia e Egito e uma distribuição global (CAREY, 1971; GUBLER, 1998a; MCSHERRY, 1982). No século XIX, inúmeras epidemias de dengue foram descritas em Zanzibar, Calcutá, Grécia e Japão. Na primeira metade do século XX, houve o aumento de endemias da doença (GUBLER, 1998a). Em 1954, a doença começou a exibir um novo padrão, o qual foi caracterizado por hemorragias ou choques, provocando óbito em $40 \%$ do enfermos. Após a década de 70, o problema das endemias de dengue agravou-se, particularmente nos países tropicais de todos os continentes.

Atualmente, a dengue representa um sério problema de saúde pública em áreas tropicais da Ásia, África, América Latina e Caribe (Figura 1). Na Ásia, África e América do Sul, as arboviroses (doenças transmitidas por mosquitos) estão reaparecendo, especialmente a dengue (WHO, 2009). De acordo com a Organização Mundial de Saúde, são 50 milhões de casos de dengue por ano no mundo. Analisando a morbidade, mortalidade e os gastos da dengue, essa é a arbovirose mais importante do mundo (MONATH, 1994; PEELING et al., 2010; SUAYA et al., 2009; WHO, 2009). Pode-se notar isso a partir de dados em que a dengue foi considerada uma endemia em mais de 100 países, que 3 bilhões de pessoas moram em áreas de risco e o número de países com casos está aumentando (WHO, 2009). Portanto, ferramentas epidemiológicas de diagnostico que sejam eficientes e de baixo custo são necessárias urgentemente para auxiliar no controle da doença (PEELING et al., 2010). 


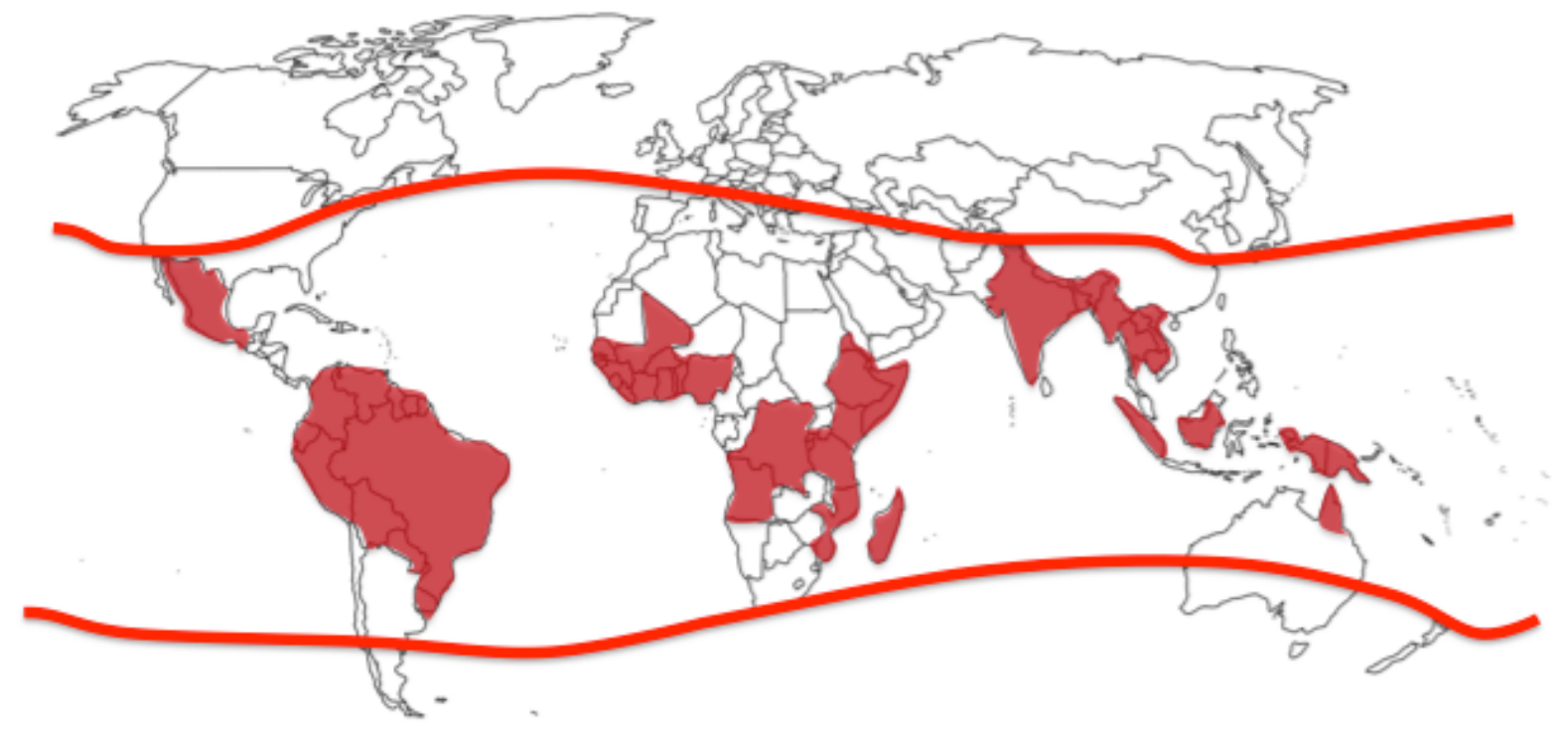

Fonte: OMS adaptado.

Figura 1 - Áreas (vermelho) em que a dengue representa um sério problema de saúde em 2010.

Nos últimos 25 anos houve um ressurgimento da dengue em vários países (GUBLER, 2004), sendo 500.000 casos de febre hemorrágica da dengue e 21.000 óbitos, acometendo principalmente crianças (ORGANIZANTION, 2009). As crianças menores de 15 anos de idade representam $90 \%$ dos casos de dengue grave, a qual tem sido uma das principais causas de internação e morte infantil em vários países (MONATH, 1994; SUAYA et al., 2009).

A dengue pode ocorrer em qualquer localidade, desde que exista população susceptível (humanos ou macacos), presença do vetor (mosquitos) e presença do vírus. Em períodos com pouca ocorrência de chuvas e temperaturas médias inferiores a $16^{\circ} \mathrm{C}$ ou superiores a $40^{\circ} \mathrm{C}$, o Aedes aegypti tem condição de sobrevivência reduzida. Contudo, nos ambientes urbanos, a oferta de criadouros artificiais como caixas d'agua destampadas, calhas entupidas, pratos de plantas cheios de água, garrafas destampadas estocadas a céu aberto, piscinas desprotegida, pneus velhos abandonados com água acumulada, entre outros, praticamente anulam os efeitos da falta de chuvas, fatores que permitem que a dengue ocorra durante todo $o$ ano nas zonas urbanas e rurais e não mais confinada ao período chuvoso (EDELMAN, 2007). 


\subsection{DENGUE NO BRASIL}

A dengue é hoje a mais importante doença viral transmitida por mosquitos que afeta seres humanos, seus vetores têm causado surtos e endemias de grande porte em vários estados brasileiros (DA CUNHA et al., 1997; NOGUEIRA et al., 1993).

Com a expansão da dengue na América Central e Caribe somada à reinfestação do Brasil pelo mosquito, um surto veio a ocorrer em Roraima pelo DENV-1 e DENV-4 causando febre da dengue em 11.000 indivíduos (OSANAl et al., 1983).

Na década de 80, o DENV-1 atingiu o estado do RJ com cerva de 95.00 casos notificados (NOGUEIRA et al., 1988; SCHATZMAYR; NOGUEIRA; TRAVASSOS DA ROSA, 1986).

$\mathrm{Na}$ década de 90 o Rio de Janeiro manifestou-se com a com dengue hemorrágica (DENV-2). A partir do Rio de Janeiro o DENV-1 se espalhou para outros estados transformando-se em um problema de saúde pública nacional. Em 1990, o Rio de Janeiro e Niterói foram afetados por um novo surto, desta vez relacionado ao DENV-2, resultando em aumento das formas graves da doença, com notificação de mais de 300 casos de dengue hemorrágica (NOGUEIRA et al., 1990). Em seguida para o estado de SP e TO, BA e CE.

Em 1998 foi identificado o DENV-3 no estado de São Paulo e em 2000 no Rio de Janeiro, o qual se disseminou por todo o país e em 2002 foram notificados 800.00 casos de dengue e 270 de dengue hemorrágica com 150 óbitos (DE FIGUEIREDO et al., 2004).

Na década de 2000 o Brasil foi o país com maior número de casos de dengue em todo o mundo, com mais de três milhões de casos relatados, esse número representa $61 \%$ de todos os casos diagnosticados no mundo (TEIXEIRA et al., 2009). Em 2009 foram 393.583 casos no Brasil (SES/UF; SINAN, 2010). Em 2010 foram 191.193 casos apenas em SP (CVE/SES-SP, 2011). Em 2011 de Janeiro a Junho de 2011 foram 73.021 casos, sendo 4.302 desses na cidade de Bauru - SP (CVE/CCD/SES-SP, 2011). Nas imagens a seguir pode-se acompanhar a evolução da dengue no estado de São Paulo (Figura 2, Figura 3 e Figura 4). 


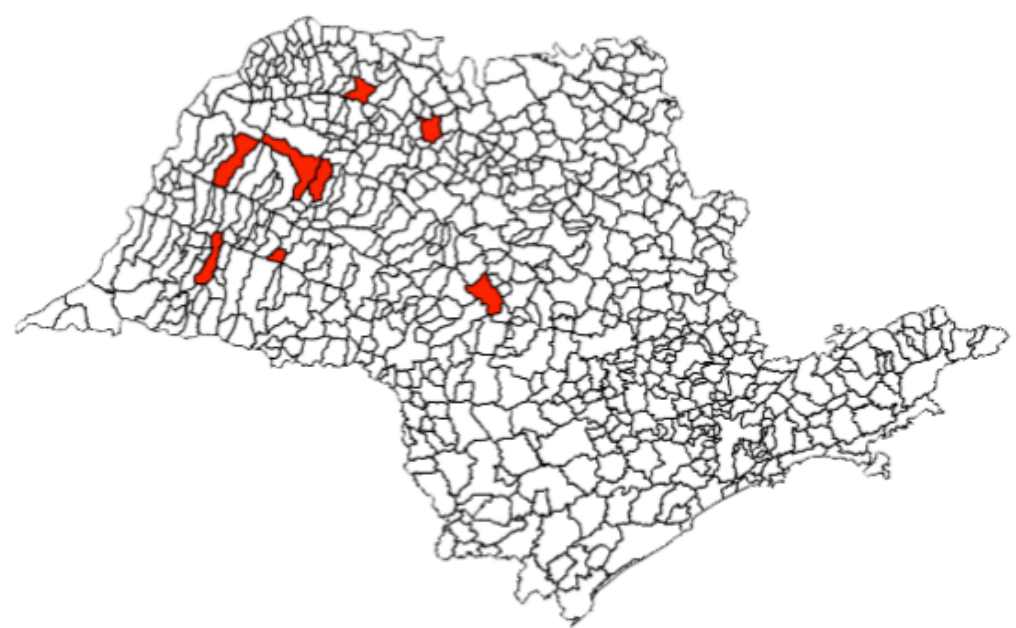

Fonte: Superintendência de Controle de Epidemias adaptado.

Figura 2 - Infestação por Aedes aegypti no Estado de São Paulo em 1985.

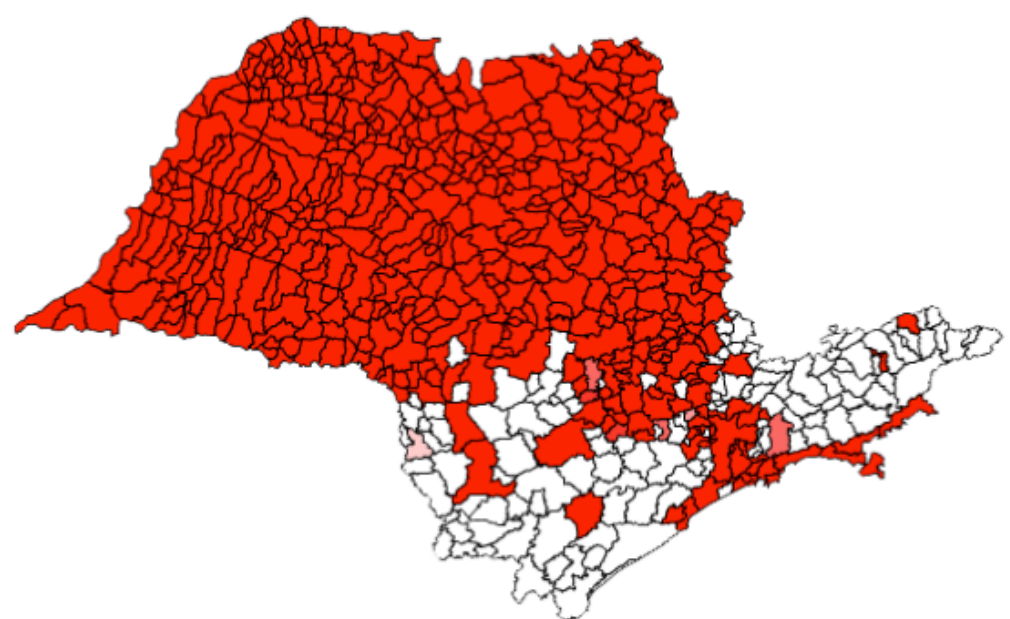

Fonte: Superintendência de Controle de Epidemias adaptado.

Figura 3 - Infestação por Aedes aegypti no Estado de São Paulo em 2005.

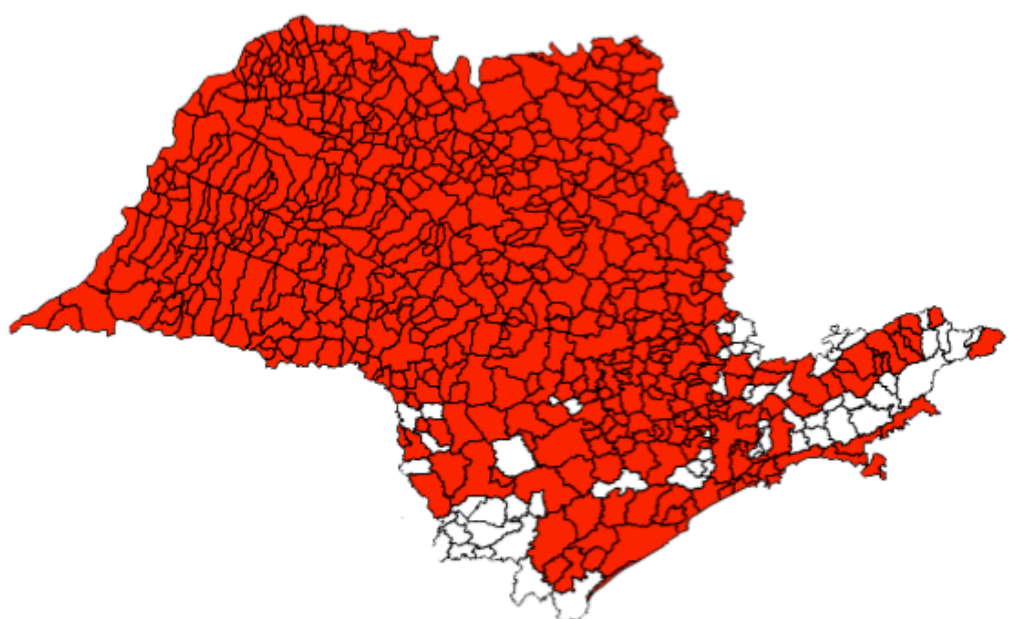

Fonte: Superintendência de Controle de Epidemias adaptado.

Figura 4 - Infestação por Aedes aegypti no Estado de São Paulo em 2011. 
Dessa forma, o risco de ocorrência da forma grave da doença tende a aumentar (ROCCO et al., 2012). Pelo fato da dengue estar contida na lista de doenças de notificação compulsória, o Ministério da Saúde orienta que todos os casos suspeitos ou confirmados sejam notificados ao Serviço de Vigilância Epidemiológica, por meio do Sistema de Informação de Agravos de Notificação SINAN (MORAES; DUARTE, 2009; PENNA, 2003). Entretanto cabe salientar que, embora seja essencial, esse sistema apresenta problemas de subnotificação e dispende muito tempo. Para minimizar este problema, sugere-se a informatização do sistema para maior rapidez e praticidade, assim um número de notificações mais próximo do que realmente ocorre poderá ser alcançado, principalmente durante endemias, quando enfermeiros poderiam realizar serviços de urgência ou emergência, mas estão preenchendo papeis em triplicatas.

\subsection{VETORES}

Os vetores são os transmissores de organismos causadores de doenças que levam os agentes patogênicos de um hospedeiro para outro. Esses vetores, na maioria das vezes, são animais invertebrados, geralmente artrópodes. Os artrópodes representam mais de $85 \%$ de todas as espécies animais conhecidas e são os vetores das doenças mais importantes. O modo mais significativo de transmissão é por meio dos mosquitos hematófagos. Neles, o patógeno se multiplica dentro do artrópode e é transmitido quando o artrópode se alimenta de sangue. A incidência de doenças transmitidas por artrópodes está em ascensão e constitui uma ameaça mundial (WEAVER; REISEN, 2010).

O agente responsável pela transmissão do dengue foi primeiramente descrito no início do século XX, por Graham Harris seguido de Ashburn e Craig. Por meio de experimentos de transmissão viral, demonstrou-se que várias espécies de mosquitos seriam capazes de transmitir o vírus (VAZEILLE-FALCOZ et al., 1999).

Em 1905, o cientista australiano Thomas Lane Bancroft descobriu que a doença era transmitida pelo mesmo vetor da febre amarela, o mosquito Aedes (do grego = odioso) aegypt (do latim = Egito), também é o principal vetor da dengue, é uma espécie hematófaga originária da África que chegou ao continente americano, pois o mosquito foi capaz de manter seu ciclo reprodutivo em reservatórios de água de navios, infectando os tripulantes na época da colonização. O mosquito possui 
hábitos diurnos, com preferencia pelo ambiente doméstico urbano onde busca abrigo da luz e de correntes de ar mais fortes, em lugares normalmente úmidos como banheiros, dispensas, cozinhas. O período do dia em que se torna mais ativo corresponde ao final da tarde e começo da noite. No entanto em locais abrigados do vento e da luz, sua movimentação pode ocorrer em outros momentos do dia. Apesar do seu tamanho reduzido, pode ser reconhecido por sua coloração preta com manchas brancas (Figura 5).

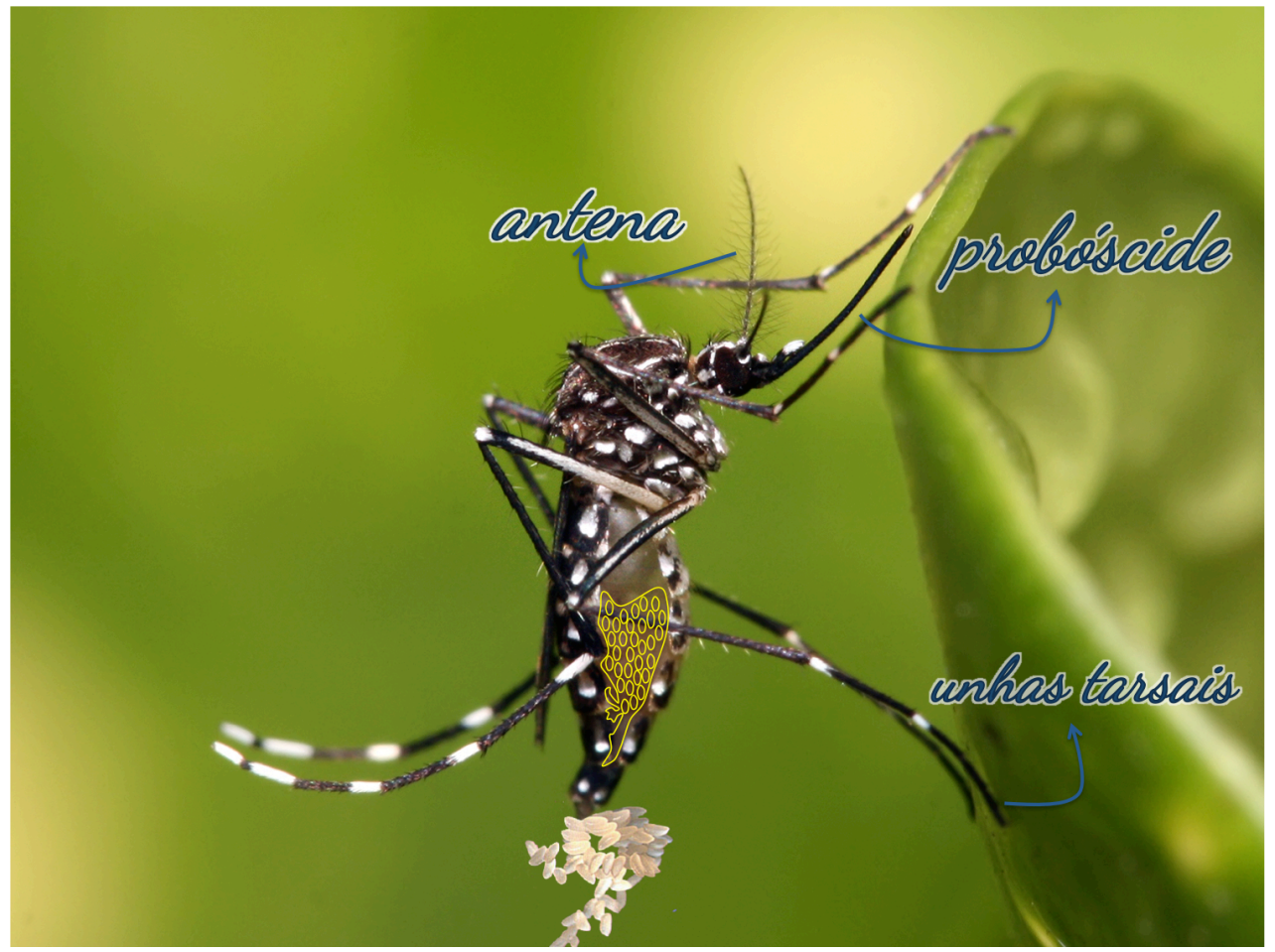

Figura 5 - Mosquito Aedes aegypti, vetor da Dengue.

Com o passar do tempo percebeu-se que o Aedes aegypti era o mais capaz de transmitir a dengue (DOHERTY, 1993), mas que outras espécies como Aedes albopictus, Aedes polynesiensis e Aedes africanus são também implicados na transmissão e estão em expansão no mundo (DA CUNHA et al., 1997; NOGUEIRA et al., 1993). 


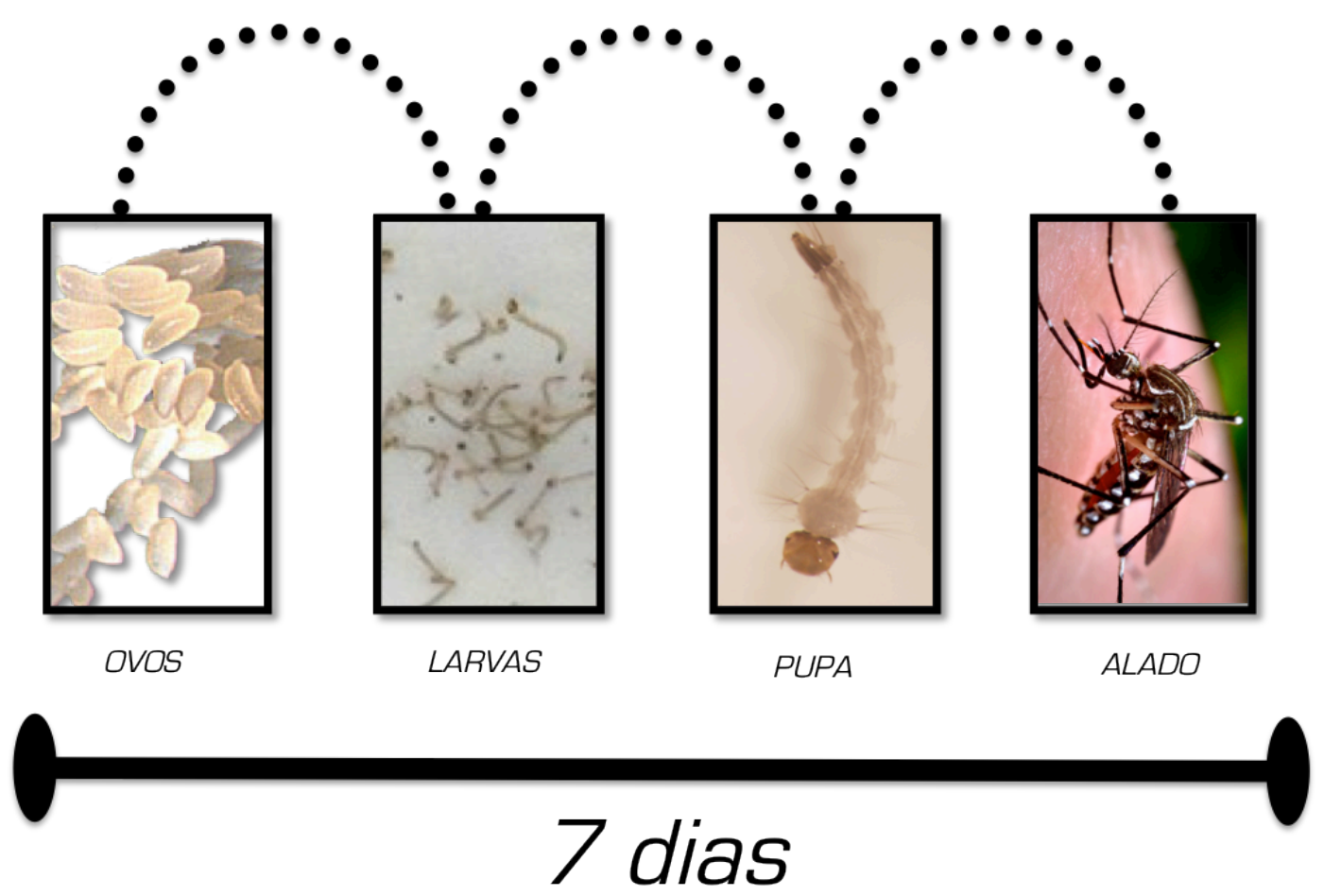

Figura 6 - Mosquito Aedes aegypti e seu ciclo biológico.

A longevidade do mosquito é de 30 a 40 dias, durante sua vida, passa por duas fases de desenvolvimento: aquática (ovo, larva e pupa) e terrestre (Figura 6). Em condições favoráveis de umidade e temperatura, a fase aquática leva de 2 a 3 dias. O conhecimento desses fatores pode auxiliar na realização de ações dos programas de proliferação do mosquito. Com o aumento da temperatura global de $2^{\circ} \mathrm{C}$ até o final do século XXI, a abrangência desse vetor pode aumentar e alcançar latitudes maiores, em locais onde nunca tenha sido identificado antes, podendo tornar-se uma ameaça de saúde pública mundial devido à falta de preparo nos novos locais de infestação.

\subsection{O VÍRUS}

O vírus da dengue faz parte da família Flaviviridae, do gênero, Flavivirus (do latim flavius = amarelo) (ROSA; PINHEIRO; VASCONCELOS, 2005; WESTAWAY et al., 1985). O vírus foi isolado pela primeira vez em 1943 durante uma endemia no Japão (SCHATZMAYR; NOGUEIRA; TRAVASSOS DA ROSA, 1986). Esse vírus faz parte do sorogrupo DENV. Embora sejam do ponto de vista epidemiológico praticamente idênticos, são reconhecidos quatro sorotipos 
antigenicamente distintos de vírus do subgrupo DENV, os quais são classificados em DENV-1, DENV-2, DENV-3 e DENV-4, sendo que qualquer um dos quatro pode causar Dengue, Dengue Hemorrágica ou Síndrome do Choque da Dengue. Baseando-se na análise das sequências genéticas dentro de cada sorotipo foram identificados diversos genótipos dentro de cada sorotipo viral (HOLMES; TWIDDY, 2003; RICO-HESSE, 1990; SABIN, 1952; WANG et al., 2000; ZANOTTO et al., 1996; ZHAN et al., 2005). O vírus apresenta morfologia esférica, com 40 a $60 \mathrm{~nm}$ de diâmetro, contendo um core de simetria icosaédrica elétron denso de $30 \mathrm{~nm}$ envolto por uma membrana bilipídica, na qual estão ancoradas as glicoproteínas de superfície. O genoma viral é constituído por RNA de fita simples com aproximadamente 11.000 pares de bases e polaridade positiva. Este genoma codifica três proteínas estruturais: proteína $\mathrm{C}$ do capsídeo, proteína $\mathrm{M}$ associada à membrana e proteína $E$ do envelope (Figura 7 ), além de sete proteínas não estruturais (NS): NS1, NS2A, NS2B, NS3, NS4A, NS4B e NS5 (RODENHUISZYBERT; WILSCHUT; SMIT, 2010) (Figura 8).

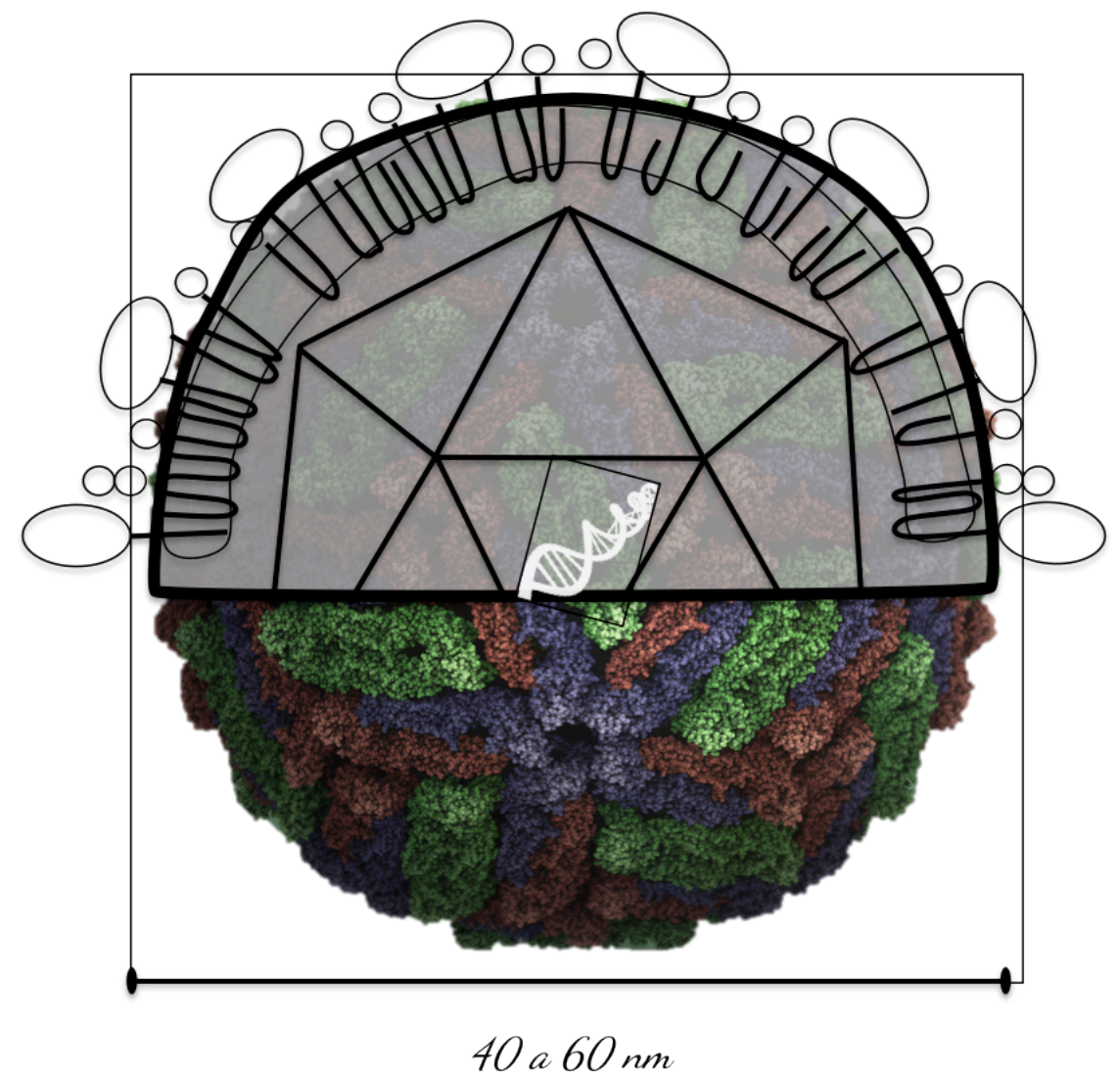

Figura 7 - Desenho esquemático do vírus dengue mostrando suas proteínas estruturais. 
O ciclo de replicação inicia-se com a entrada do vírus na célula alvo (BRESSANELLI et al., 2004). Esta fusão libera o genoma viral (composto por uma fita simples positiva de RNA) no citoplasma. Este genoma é processado e traduzido em poliproteínas virais estruturais e não estruturais. (FERNANDEZ-GARCIA et al., 2009; LINDENBACH; RICE, 2003; LOZACH et al., 2005).

\subsection{CICLO DE TRANSMISSÃO}

Originalmente o vírus da dengue circulava e era mantido em primatas inferiores e mosquitos, contudo, nos últimos três séculos, a doença se estabeleceu nos centros urbanos das regiões tropicais, no seguinte ciclo: homem - Aedes aegypti - homem (FIGUEIREDO, 2006). A transmissão sem envolvimento do vetor já foi relatada em indivíduos que se acidentaram com materiais perfurocortantes contaminados com sangue de doentes, em transfusão de sangue e em pacientes submetidos a transplante de medula óssea (BOUSSEMART et al., 2001; CHEN; WILSON, 2005; TAMBYAH et al., 2008; THAITHUMYANON et al., 1994).

A necessidade da fêmea do mosquito sugar sangue humano para sua alimentação e maturação de seus ovos provê o mecanismo para a transmissão do vírus da dengue. Quando o mosquito ingere sangue de um hospedeiro virêmico ocorre infecção das células epiteliais do intestino médio, carreado pela hemolinfa. O vírus infecta as glândulas salivares e é secretado na saliva durante o repasto do inseto em outro hospedeiro vertebrado susceptível, fechando o ciclo de transmissão da doença. $O$ intervalo de tempo entre a ingestão do sangue infectado e a secreção salivar do vírus é de 8 a 11 dias, o que pode ser acelerado por aumento na temperatura ambiente (PONTES; RUFFINO-NETTO, 1994).

Após a picada do mosquito, as células dendríticas da pele (células de Langherans) são as primeiras a serem infectadas e possuem um papel crítico no início da disseminação viral e na patogênese da doença (SAKUNTABHAl et al., 2005), visto que algumas delas podem migrar para linfonodos regionais de onde o vírus se dissemina por meio dos vasos linfáticos para o ducto torácico e daí para a circulação sanguínea (MAROVICH et al., 2001; WU et al., 2000). 


\subsection{QUADRO CLÍNICO}

A infecção com qualquer um dos quatro sorotipos de dengue pode levar a um amplo espectro clínico, que vai desde infecção assintomática ou uma doença semelhante à gripe conhecida como febre da dengue clássica, com baixa taxa de mortalidade, até hemorragias e extravasamento de plasma, que podem levar à morte, conhecida como síndrome do choque da dengue ou dengue hemorrágica (BURKE et al., 1988; HALSTEAD, 1988; MARTINA; KORAKA; OSTERHAUS, 2009).

$\mathrm{Na}$ forma clássica da doença, ausência de sintomas é comum, mas, nos casos sintomáticos, os sintomas instalam-se de modo abrupto de 2 a 8 dias após a picada, quando surge febre alta que dura de 2 a 7 dias, calafrios, cefaleia intensa, dor retro-orbitária, astenia, dor musculoesquelética, dores abdominais intensas, anorexia, náuseas e vômitos. (GUZMAN; KOURI, 2002). Exantema generalizado também pode ocorrer, sendo de caráter transitório, costuma aparecer no primeiro ou segundo dia de evolução. A contagem total de leucócitos é diminuída e podem ocorrer trombocitopenia e fenômenos hemorrágicos leves. A dengue clássica é usualmente autolimitada, porém a convalescença é prolongada, com persistência das queixas de fadiga, prostração e dores por até 6 meses após o aparecimentos dos primeiros sintomas.

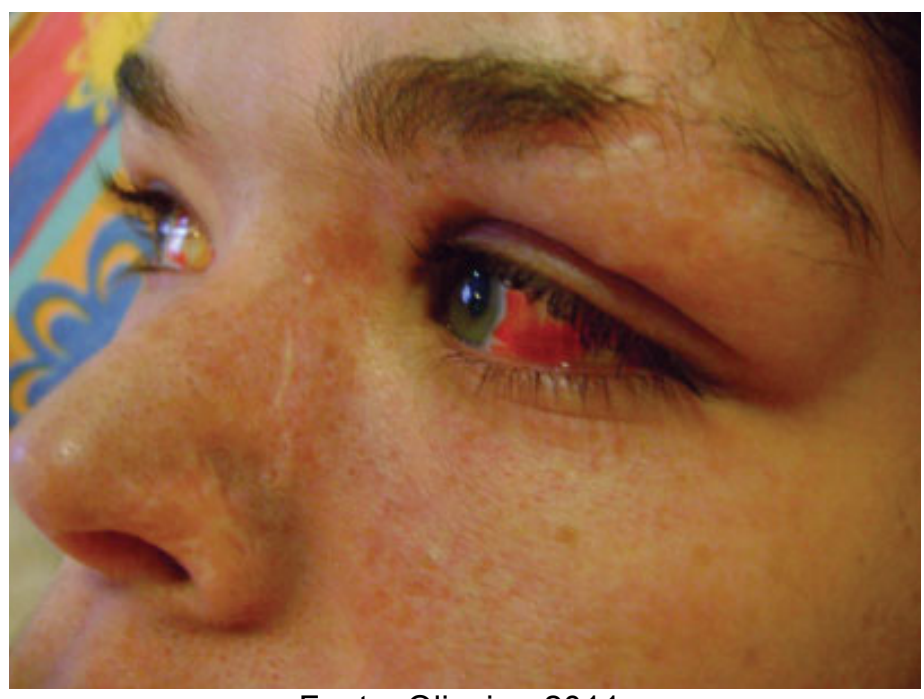

Fonte: Oliveira, 2011.

Figura 8 - Exantema petequial em face e hiposfagma. 


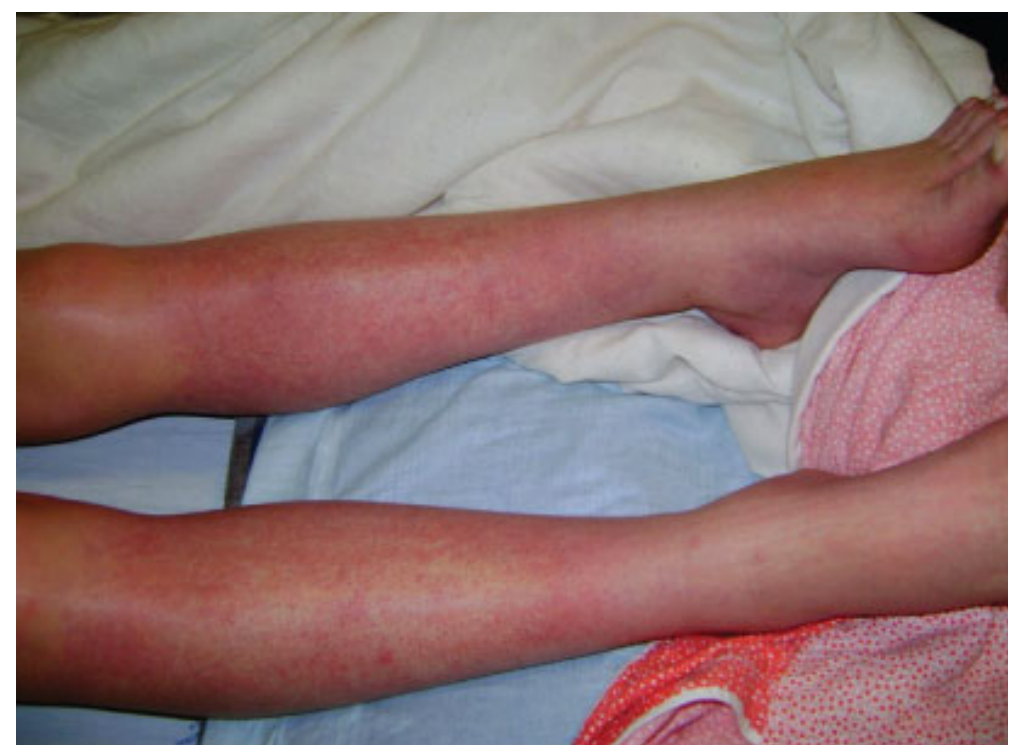

Fonte: Oliveira, 2011.

Figura 9 - Exantema petequial em membros inferiores.

\subsection{PATOGENIA DAS FORMAS GRAVES}

Devido, principalmente, às formas mais graves da doença, estima-se que o DENV provoca mais de meio milhão de hospitalizações anualmente, com taxas de mortalidade que variam entre $1 \%$ e $5 \%$, principalmente em crianças (WILDERSMITH et al., 2010) (WILLS et al., 2002).

Quando um indivíduo se infecta, não é possível saber se ele desenvolverá formas mais leves da doença ou se evoluirá para dengue hemorrágica ou choque da dengue, pois a patogênese da doença grave ainda não está totalmente esclarecida, existem, pelo menos, três possíveis explicações. Uma delas avalia a maior susceptibilidade genética ou presença de doenças como diabetes, alergia e hipertensão e sugere que essas comorbidades sejam um fator de risco para dengue hemorrágica (FIGUEIREDO et al., 2010).

Outra teoria está relacionada com a virulência de algumas estirpes do vírus. É sabido que a proteína NS1 do vírus pode induzir a uma doença autoimune em alguns pacientes: anticorpos dirigidos contra a proteína NS1 apresentam reatividade cruzada com plaquetas sanguíneas e células endoteliais, culminando em disfunções plaquetárias e danos no próprio endotélio (LIN et al., 2008; LIU et al., 2006). 
Mas as evidências sugerem que a terceira teoria é a mais próxima da realidade: infecções sequenciais causadas por sorotipos diferentes do vírus têm um papel importante na patogênese da dengue grave. Altas taxas de infestação pelo Aedes aegypti, a circulação de mais de um sorotipo do vírus, as altas densidades populacionais e o intenso deslocamento geográfico das pessoas também estão relacionados à ocorrência de casos graves. Tem sido observado que o risco de dengue hemorrágica é cerca de 20 vezes maior na infecção secundária que na primária (HALSTEAD, 1970). Se o hospedeiro for infectado com um segundo sorotipo, antes do nível de anticorpos atingirem um segundo limiar, pode ocorrer um aumento da replicação viral (reforço) (BRAVO; GUZMAN; KOURI, 1987) (HALSTEAD, 1989; MONGKOLSAPAYA et al., 2003).

\subsection{TRATAMENTO}

Nos casos de dengue clássica, procede-se ao tratamento sintomático da febre, cefaleia, mialgias e artralgias, bem como se cuida da reposição hidroeletrolítica por via oral. Atualmente não existe uma droga antiviral disponível para uso clínico com ação efetiva contra o vírus da dengue (MURPHY; WHITEHEAD, 2011; WILDER-SMITH et al., 2010). Embora não exista o tratamento antiviral específico, nos casos suspeitos de dengue hemorrágica a precocidade na reposição hídrica e de eletrólitos por via oral ou intravenosa tem um papel crucial na redução da mortalidade. Nos pacientes com choque da dengue (letargia, extremidades frias, cianose perioral, pulso fino e rápido, hipotensão), a hemocentração mantém-se apesar da reidratação. Trata-se de uma emergência médica que requer observação contínua e imediata expansão plasmática até que as condições hemodinâmicas se normalizem. A evolução para a cura depende da disponibilidade dos cuidados intensivos e do tratamento precoce das alterações hemodinâmicas.

\subsection{CONTROLE}

As fêmeas do vetor, como se sabe, põem ovos à beira de água parada. Os programas educativos instruem rotineiramente o morador a tampar reservatórios, 
baldes, pratos de vasos de planta e outros recipientes de água de uso doméstico, além de instruí-lo quanto aos cuidados com instalações vulneráveis, como as calhas de telhado. Ênfase tem sido dada ao controle das larvas, mas com a rápida expansão das áreas urbanas esta tarefa torna-se impossível sem a colaboração efetiva da população (GUBLER, 1989). Geralmente a esfera governamental que está diretamente envolvida com as atividades de controle da dengue é a municipal, que conta com recursos limitados para a realização de todas as atividades de controle.

Trabalhos mostram que a prevenção por meio da vacinação seria a melhor abordagem e de melhor custo-benefício para prevenir a dengue hemorrágica (SHEPARD et al., 2004). Recentemente várias potenciais vacinas tem sido desenvolvidas, mas ainda é precipitado dizer que tais esforços resultarão em uma vacina efetiva e economicamente viável para ser futuramente usada na prevenção da dengue (HALSTEAD; DEEN, 2002).

O controle ainda é a melhor solução para a dengue e para a melhoria na qualidade de vida. Agilidade e precisão na obtenção das respostas pode impactar diretamente na tomada de decisões, aumentando a chance do rápido controle. Com o diagnóstico rápido e preciso é possível oferecer respostas rápidas como: onde foi identificado o primeiro caso; quem foi o primeiro infectado; qual a área de espalhamento da doença; quais domicílios estão no raio de autonomia de voo dos mosquitos; existência de algum morador já infectado.

\subsection{DIAGNÓSTICO}

No Brasil, a dengue é diagnosticada com frequência apenas com base nos sintomas clínicos. Mas, clinicamente, o diagnóstico da dengue é, ao mesmo tempo, importante e difícil de ser realizado. Difícil pelo fato de que os sintomas não são suficientemente específicos, mas sim semelhantes aos de outras infecções febris agudas, como malária, tifo, leptospirose, sarampo, rubéola, gripe e várias arboviroses, todas incluídas no diagnóstico diferencial da dengue; e importante devido à grande dispersão geográfica, à ocorrência de surtos, às reinfecções, à predominância urbana, à ocupação de leitos nos hospitais e aos efeitos econômicos sobre o governo e em especial à dificuldade de tratamento (DEROECK; DEEN; CLEMENS, 2003; OLIVEIRA et al., 2010; TOLEDO et al., 2006). O diagnóstico definitivo da infecção pelo DENV somente pode ser realizado laboratorialmente, 
sendo altamente recomendado o exame laboratorial em casos de suspeita. Diagnóstico preciso e eficaz é essencial para a vigilância de doenças e, assim, a confirmação laboratorial é recomendada (ARTIMOS DE OLIVEIRA et al., 1999). Existem quatro de exames laboratoriais capazes de identificar o vírus da dengue de formas diferentes (HALSTEAD, 2007; PEELING et al., 2010; SHU; HUANG, 2004). Todos eles exigem amostras sanguíneas (ARTIMOS DE OLIVEIRA et al., 1999).

\subsubsection{Isolamento Viral}

O principal método utilizado para o isolamento viral é a inoculação da amostra suspeita em mosquitos, em cultura de células ou em camundongos recém nascidos. Como a viremia coincide com o período febril, o índice de isolamento é significantemente maior naquelas amostras coletadas até o sexto dia de instalação da doença (KAO et al., 2005). O vírus da dengue normalmente não apresenta bom crescimento in vitro e, até o momento, um dos mais sensíveis métodos de isolamento é in vivo por meio da inoculação em mosquitos. Quatro espécies nas quais machos e fêmeas são igualmente susceptíveis tem sido usada para isolamento viral: Aedes aegypti, Aedes Albopictus, Toxorhynchites amboinensis e Toxorhynchites splendens. Para diminuir o risco de infecção laboratorial, podem ser usados mosquitos Aedes machos ou mosquitos não hematofágicos como o Toxorhynchites. Somente após dez dias de incubação, a presença do vírus é avaliada nas glândulas salivares dos mosquitos através de imunofluorescência direta. $O$ isolamento viral por inoculação em mosquitos tem como desvantagens, além do risco de infecção laboratorial, o fato de ser uma técnica excessivamente laboriosa e de necessitar da criação e manutenção de um insetário para produção de um grande numero de mosquitos, o que não está disponível na maioria dos laboratórios de virologia (PHILIP SAMUEL; TYAGI, 2006).

Em relação à inoculação em culturas de células, método mais utilizado para isolamento viral, são comumente empregadas células tais como C6/36 (Aedes albopictus), AP61 (Aedes pseudoscutellaris) e RA-284 (Toxorhynchites amboinensis) derivadas de mosquitos, além de células de rim de macaco verde africano. Após período de incubação de uma semana, o vírus pode ser detectado por métodos sorológicos (imunofluorescência) ou moleculares. A inoculação em cultura celular é um método de alta especificidade, porém, não é usado rotineiramente porque 
demanda longo período de tempo (usualmente mais que sete dias) para se completar o teste. Finalmente, o isolamento viral por inoculação intracerebral em camundongos recém-nascidos é mais sensível que a cultura celular, entretanto, este é um método laborioso, caro e de difícil implementação na rotina.

Os métodos de isolamento viral permanecem como padrão ouro para diagnóstico definitivo, todavia os testes sorológicos para detecção de anticorpos dos tipos lgM e/ou IgG são os mais amplamente utilizados.

\subsubsection{Detecção de Anticorpos}

Os métodos que detectam anticorpos antidengue são os mais usados para o diagnóstico da doença. Os cinco principais métodos sorológicos para detecção de anticorpos são: inibição da hemaglutinação (IH), de fixação do complemento (FC), neutralização e ELISA (Enzyme Linked Immunosorbent Assay) (KAO et al., 2005).

O ELISA é considerado, nos dias atuais, o mais útil teste de detecção de anticorpos antidengue devido à sua alta sensibilidade e facilidade técnica. ELISA clássico e ELISA de captura de anticorpos são os dois formatos mais comumente utilizados. Os anticorpos podem ser detectados tanto na fase aguda, a partir do quinto dia do início dos sintomas (anticorpos da classe $\lg M$ ), quando na fase de convalescença (anticorpos da classe lgG). Os títulos de IgM são significativamente mais altos na infecção primária do que nas infecções secundária e terciária, quando a sua produção é muito baixa e transitória; deste modo, o índice dado pela razão entre as leituras ópticas dos títulos de $\operatorname{lgM} / \lg$ pode ser usado para a diferenciação entre infecção primária e secundária (SHU et al., 2003). Este método torna-se inviável para a proposta de diagnóstico precoce uma vez que detecta anticorpos a partir do quinto dia de instalação dos sintomas. Além disso, a detecção desses anticorpos em um paciente febril numa primeira coleta não é suficiente para confirmar o diagnóstico. É necessária mais uma coleta de amostra de sangue com pelo menos 7 dias de intervalo da primeira coleta para a comparação dos níveis de anticorpos. Esse procedimento atrasa o diagnóstico e o tratamento, acrescentandose ainda que os níveis de anticorpos podem ficar alterados por 8 meses, dificultando 
o diagnóstico em áreas endêmicas (ALEXANDER DÍAZ-QUIJANO et al., 2006; BALMASEDA et al., 2003; GADKARI; SHAIKH, 1984).

\subsubsection{Detecção de Antígenos}

É mais moderno e é feito através da identificação de proteínas específicas deste vírus, o qual possui: três proteínas estruturais (proteína $C$, proteína $\mathrm{M}$ e proteína E) e outras proteínas não estruturais (NS1, NS2a, NS2b, NS3, NS4a, NS4b, NS5), que estão relacionadas com a infecção viral (CHAMBERS et al., 1990; LINDENBACH; RICE, 2003). Em amostras de soro, durante a fase aguda da doença, pode ser detectado o antígeno NS1. Trata-se de uma das glicoproteínas não estruturais do vírus altamente conservada e que, durante a fase aguda da infecção, passa a ser expressa na superfície das células infectadas bem secretada para a circulação sanguínea, podendo ser detectada. Recentemente, altos níveis de NS1 foram demonstrados por ELISA em pacientes na fase aguda da doença (ALCON et al., 2002; JESSIE et al., 2004; KITTIGUL et al., 1997; LIBRATY et al., 2002; MIAGOSTOVICH et al., 1997).

Tem-se mostrado que a proteína NS1 circula, durante a fase aguda da doença, no plasma de pacientes infectados com o vírus da dengue (ALCON et al., 2002; SHU; HUANG, 2004; YOUNG et al., 2000). A NS1 é uma glicoproteína nãoestrutural secretada por células infectadas pelo vírus durante a fase aguda da dengue (YOUNG et al., 2000) e é essencial para a viabilidade do vírus (MACKENZIE; JONES; YOUNG, 1996).

Os mais recentes diagnósticos de dengue são feitos através da identificação da proteína não-estrutural NS1 pelo teste ELISA ou através de um teste rápido imunocromatográfico. Este último, muito eficaz para o diagnóstico precoce da infecção, fornece resultados em 15 minutos. Um trabalho publicado em 2011, testou o exame rápido de NS1 em amostras de sangue (NS1 Ag Stip Bio-Rad Laboratories, França), o qual teve sensibilidade e especificidade de $77,3 \%$ e $100 \%$, respectivamente, aos 15 minutos, e $80,5 \%$ e 100\%, respectivamente, aos 30 minutos. Comparando infecção primária e secundária, a tira NS1 apresenta menor sensibilidade para infecções secundárias, nas quais a pré-existência de anticorpos poderia inibir a detecção do antígeno NS1 (CHATERJI et al., 2011). 


\subsubsection{Detecção do Genoma Viral}

As técnicas moleculares, cujo objetivo é a detecção do genoma viral, tem importante papel no diagnóstico da dengue, uma vez que são capazes de identificar o vírus na fase aguda da doença e, em algumas metodologias, quantificar a carga viral. Entre os métodos mais utilizados, pode-se citar a hibridização e a transcrição reversa combinada à reação em cadeia da polimerase (RT-PCR) convencional ou em tempo real (GUBLER, 1998b).

A RT-PCR convencional é um método que possibilita a amplificação de sequências genômicas específicas de RNA delimitadas por iniciadores (primers). Uma alíquota deste produto de amplificação deve ser submetida a eletroforese em gel de agarose para posterior coloração com brometo de etídeo e, então, deve ser visualizado sob iluminação ultravioleta para confirmação da detecção do genoma viral (BARKHAM et al., 2006; GUZMAN; KOURI, 1996; LANCIOTTI et al., 1992).

A RT-PCR em tempo real, assim como a convencional, possibilita a amplificação de fragmentos genômicos (NIESTERS, 2002). A RT-PCR em tempo real apresenta sensibilidade maior que o isolamento e RT-PCR convencional é equivalente à nested RT-PCR convencional (MACKAY; ARDEN; NITSCHE, 2002).

Várias estratégias de marcação vem sendo utilizadas para a detecção do fragmento amplificado, algumas usam substâncias fluorescentes que se ligam ao DNA dupla fita como SYBR green, e outras usam sondas marcadas. As estratégias que utilizam sondas marcadas são altamente sensíveis e específicas. As três metodologias mais utilizadas são ensaio fluorogênico da atividade 5'nuclease (TaqMan®), sonda de hibridação molecular beacons (oligonucleotídeos que formam uma estrutura secundária entre as extremidades 5'e 3') e sonda de hibridação FRET (fluorescence resonance energy transfer). Estas sondas são desenhadas com base na sequência do fragmento alvo a ser amplificado e contêm um corante fluorescente ligado ao seu término 5' (reporter) e um inibidor da fluorescência (quencher) ligado ao seu término 3'. Durante o processo de amplificação, a sonda híbridiza uma região específica do produto amplificado; após a hibridação, o reporter e o quencher são separados, ocorrendo assim a emissão da fluorescência que é diretamente proporcional à quantidade do material genético alvo presente na amostra. Trabalhos 
usando TaqMan® descrevem sua capacidade de detectar e quantificar a carga viral por RT-PCR numa única etapa (CHAO; DAVIS; CHANG, 2007).

As estratégias que utilizam RT-PCR apresenta alta sensibilidade e especificidade, embora rápidas e eficazes em fornecer o diagnóstico precoce da dengue, são dispendiosas, caras e exigem pessoal altamente treinado para execução, além de excessivamente laborioso. É, portanto, apenas disponível num número limitado de laboratórios. Esta técnica é altamente sensível e específica para o diagnóstico precoce de infecção por dengue mesmo quando os anticorpos ainda são baixos, ou seja, uma ferramenta importante para o diagnóstico rápido da infecção pelo DENV, permitindo o início precoce do tratamento do paciente e específicas medidas preventivas de saúde (DOS SANTOS et al., 2008; DROSTEN et al., 2002; HOUNG et al., 2001; JOHNSON; RUSSELL; LANCIOTTI, 2005; LAI et al., 2007; LAUE; EMMERICH; SCHMITZ, 1999; TORRES; LIPRANDI; GONCALVEZ, 2000).

\subsection{REVISÃO SISTEMÁTICA DA LITERATURA - DIAGNÓSTICO DA DENGUE ATRAVÉS DA SALIVA}

Muitas ferramentas de diagnóstico da dengue tornaram-se disponíveis, porém requerem coleta de sangue como amostra para análise. A necessidade de uma coleta de sangue venoso em todos os ensaios de diagnóstico de dengue pode dificultar a detecção precoce de casos de dengue e, portanto, poderiam retardar os esforços de controle de vetores. Um método não invasivo de confirmar a infecção por dengue seria de importância considerável para os estudos clínicos e epidemiológicos. Acredita-se que testes de saliva podem encorajar os pacientes a serem mais receptivos para o diagnóstico da dengue.

Possíveis problemas com o uso de sangue incluem a exigência de consentimento e a cooperação do paciente. Em muitos casos, flebotomia em indivíduos com fobia de agulhas, portadores de deficiências e discrasias sanguíneas e, especialmente em bebês e crianças - o grupo mais afetado pela dengue em áreas onde a infecção é endêmica - pode representar um desafio. Ou ainda é difícil devido a razões sociais, religiosas, à necessidade de um enfermeiro treinado e à necessidade de se separar o soro do plasma antes do teste (BROWN et al., 1994). 
A maioria dos fluidos corporais contêm anticorpos, embora em níveis muito mais baixos do que os de sangue. Anticorpos específicos na saliva foram relatados para serem úteis métodos alternativos para o diagnóstico da infecção pelo vírus da dengue (BALMASEDA et al., 2003). Infecções por dengue foram caracterizadas pela elevação de $\operatorname{lgM}$ ou lgG. Na saliva, as concentrações de anticorpos são 19,9 mg/100 ml (lgA), 1,4 mg/100 ml (lgG), e de 0,2 mg/100 ml (IgM), e esses níveis são de cerca de 1/10,1/800, e 1/400 comparados com amostras de sangue (PARRY; PERRY; MORTIMER, 1987).

A primeira utilização relatada do diagnóstico da dengue pela saliva foi do vírus tipo 1 por meio da PCR-RT usando primers universais para o vírus da dengue no quarto dia de febre, utilizando $200 \mathrm{~mL}$ de saliva (TORRES; LIPRANDI; GONCALVEZ, 2000). Em seguida mais um trabalho com as mesmas características foi realizado em um segundo paciente (MIZUNO et al., 2007). Os vírus tipo 1 e 3 foram encontrados na saliva de mais dois paciente no segundo dia de febre e não foram encontrados no nono dia de febre, para ambos pacientes. Todos esses trabalhos os diagnósticos com saliva confirmados utilizando amostras de sangue. $A$ identificação de anticorpos também é relatada na saliva, com lgM em infecção recentes (CUZZUBBO et al., 1998) (ARTIMOS DE OLIVEIRA et al., 1999) (CHAKRAVARTI; MATLANI; JAIN, 2007), IgA (BALMASEDA et al., 2008) e IgG em infeção convalescentes.

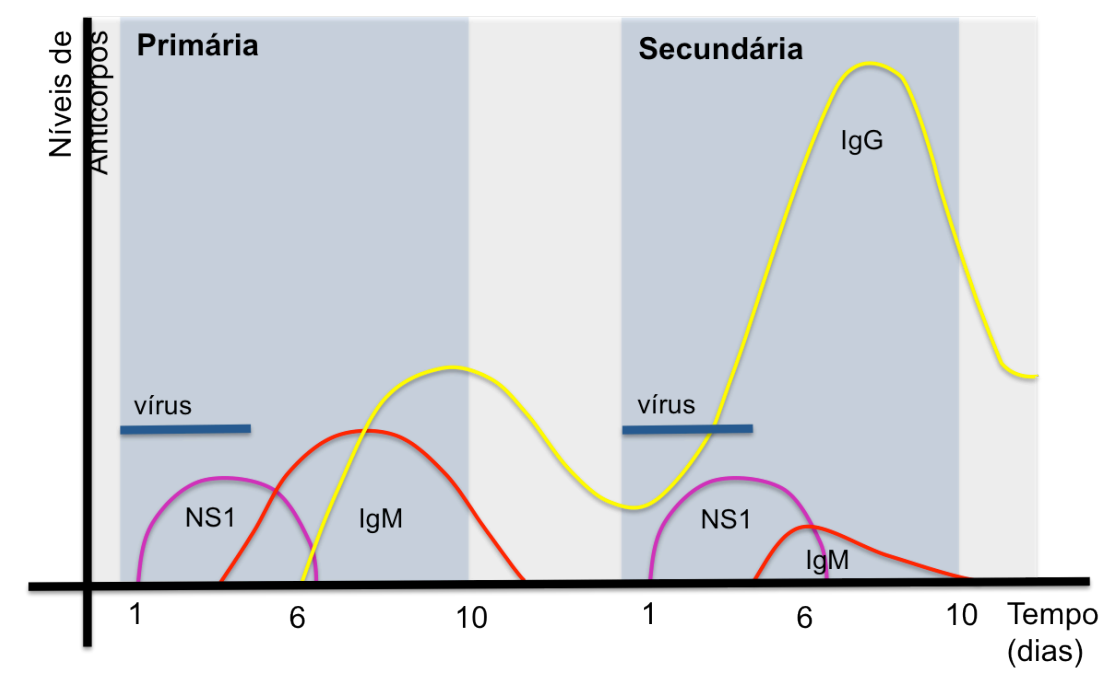

Figura 10 - Gráfico mostrando os níveis de NS1, IgM e IgG de acordo com o período febril em uma infecção de dengue.

A existência de ambas as partículas virais, ou vírus inteiro, ou do genoma viral na saliva não é surpreendente, uma vez que tanto os linfócitos quanto os 
macrófagos podem ser normalmente encontrados na saliva e uma vez que as hemorragias microscópicas das gengivas são habituais em muitos pacientes que têm dengue ou dengue hemorrágica. A menor carga viral presente na saliva em comparação com o soro sugere que o vírus da dengue seria detectado nestas amostras clínicas por um curto período de tempo (POLONI et al., 2010).

O aumento da doença e os custos que a dengue representa têm impulsionado a proliferação de testes para o diagnóstico da dengue. Para garantir a qualidade e o desempenho do teste, existe a necessidade de uma avaliação independente dos fabricantes de testes de diagnóstico da dengue (PEELING et al., 2010).

Denomina-se revisão sistemática da literatura a revisão planejada da literatura científica, que usa métodos sistemáticos para identificar, selecionar e avaliar criticamente estudos relevantes sobre uma questão claramente formulada. $O$ objetivo da sistematização é reduzir possíveis vieses que ocorreriam em uma revisão não-sistemática (HALLIGAN, 2005).

Meta-análise é o método estatístico utilizado na revisão sistemática para integrar os resultados dos estudos incluídos e aumentar o poder estatístico da pesquisa primária (SACKS et al., 1996).

Nesta revisão sistemática avaliaram-se os trabalhos da literatura que avaliaram marcadores salivares utilizados para diagnóstico da dengue.

O guia "Preferred Reporting Items for Systematic Reviews and MetaAnalyses (PRISMA)" foi usado durante a busca e escrita de todas as fases desta revisão. O PRISMA inclui uma lista de verificação de 27 itens criado para ser aplicado em revisões sistemáticas (SWARTZ, 2011).

Foi realizada a busca eletrônica dos artigos nas seguintes bases de dados: Pubmed/Medline, Embase, Ovid, ISI Web of Science e Cochrane Library. A estratégia de busca foi baseada nos seguintes descritores: "dengue" AND "saliva". Não houve restrições de idiomas. Esta busca foi realizada por dois autores de forma independente. Os artigos selecionados foram os publicados até fevereiro de 2013.

$\mathrm{Na}$ busca, inicialmente foram selecionados 127 artigos. Depois, os títulos duplicados foram removidos restando 57 estudos. A revisão do título, do resumo e do artigo completo reduziu para 11 artigos elegíveis, todos publicados em Inglês. Um diagrama de fluxo de processo de inclusão e exclusão dos artigos encontra-se ilustrada na Figura 11. 


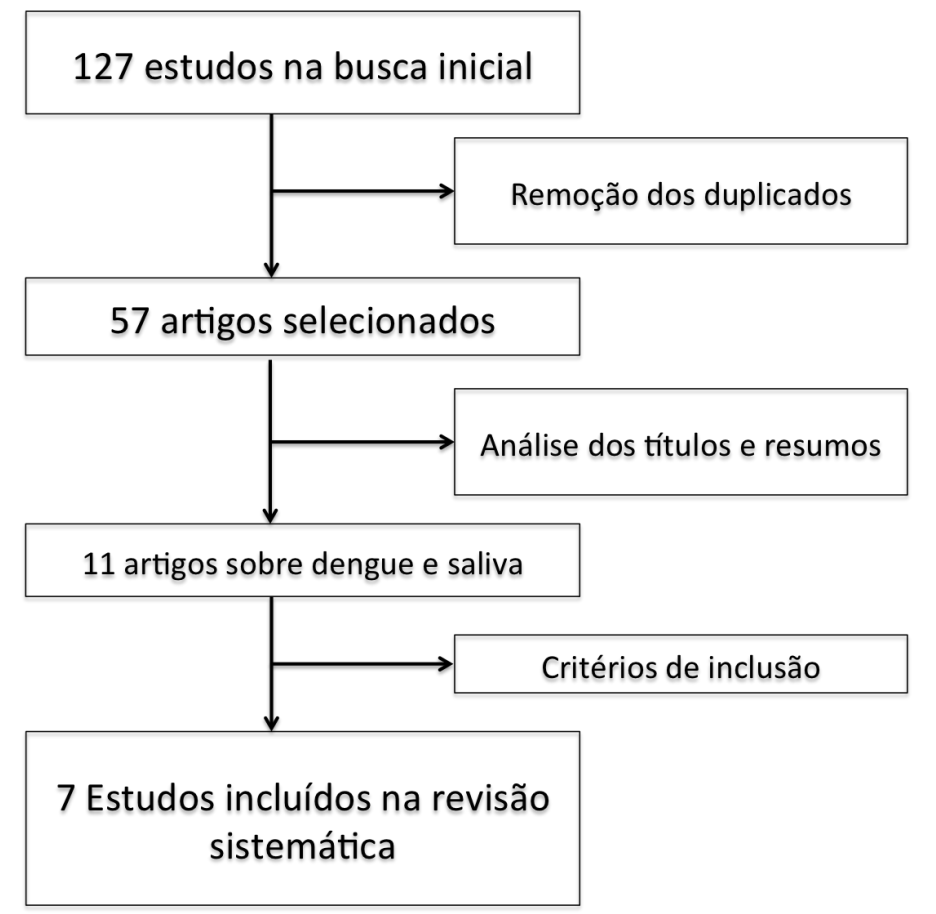

Figura 11 - Desenho esquemático dos trabalhos incluídos na revisão sistemática.

Para um artigo ser incluído na revisão deveria seguir os seguintes critérios de inclusão:

- Avaliar biomarcadores de diagnóstico da infecção pelo vírus da dengue na saliva;

- Disponibilizar ou permitir calcular as taxas de verdadeiro positivo, falso positivo, verdadeiro negativo e falso negativo.

- Ser um estudo com grupo controle;

- Utilizar um método de diagnóstico "gold-standard" como comparação.

Após a aplicação desses critérios, sete estudos foram incluídos nessa revisão, os quais estão detalhados na tabela 1. Entre eles, quatro estudos foram realizados na Ásia e três estudos foram realizados na América, não foram selecionados estudos efetuados na África, Europa e Oceania. 
Tabela 1 - Característica dos artigos incluídos na revisão sistemática.

\begin{tabular}{|c|c|c|c|c|c|}
\hline Autor, ano & País & $\begin{array}{l}\text { Tipo do } \\
\text { estudo }\end{array}$ & $\begin{array}{l}\text { Amostra } \\
\text { referência }\end{array}$ & $\begin{array}{l}\text { Seleção de } \\
\text { pacientes }\end{array}$ & $\begin{array}{r}\text { Número } \\
\text { de } \\
\text { pacientes }\end{array}$ \\
\hline (CUZZUBBO et al., 1998) & Tailândia & Prospectivo & Sangue & Consecutiva & 52 \\
\hline $\begin{array}{l}\text { (ARTIMOS DE OLIVEIRA et } \\
\text { al., 1999) }\end{array}$ & Brasil & Prospectivo & Sangue & Consecutiva & 46 \\
\hline (BALMASEDA et al., 2003), & Nicarágua & Prospectivo & Sangue & Consecutiva & 348 \\
\hline $\begin{array}{l}\text { (CHAKRAVARTI; MATLANI; } \\
\text { JAIN, 2007) }\end{array}$ & Índia & Prospectivo & Sangue & Consecutiva & 80 \\
\hline (BALMASEDA et al., 2008), & Nicarágua & Prospectivo & Sangue & Consecutiva & 356 \\
\hline (YAP; SIL; NG, 2011) & Singapura & Prospectivo & Sangue & Consecutiva & 154 \\
\hline (ANDERS et al., 2012) & Vietnã & Prospectivo & Sangue & Consecutiva & 105 \\
\hline
\end{tabular}

\subsubsection{Avaliação da Qualidade dos Estudos}

Os trabalhos que preencheram os critérios de inclusão foram avaliados por meio da Avaliação da Qualidade de Estudos da Precisão de Diagnósticos (Quality Assessment of Diagnostic Accuracy Studies - QUADAS) a qual é composta por 14 itens (Figura 12), cada item tem as opções "sim", "não" ou "insuficiente". O "sim" indica informações suficientes, com viés improvável. O "não" indica uma informação suficiente, mas com potencial viés de conduta inadequada. $O$ "insuficiente" indica que a informação não foi fornecida no artigo ou a metodologia não era clara. A pontuação total é feita com a contagem de todos os critérios que marcaram "sim", que foi avaliado com "1", enquanto, "não" e "insuficiente" tem a pontuação "zero". A pontuação máxima possível na lista de critério é de 14.

A qualidade metodológica de cada um dos estudos foi independentemente avaliada por ambos os autores. Divergências foram discutidas e resolvidas durante uma reunião. Qualitativamente, os estudos que apresentam valores mais elevados do QUADAS estão associados com um menor risco de viés do que os valores mais baixos. Estudos semelhantes publicados anteriormente estratificam como "de alta qualidade / baixo risco de viés", se a pontuação QUADAS 
foi 10 ou maior, e "baixa qualidade / alto risco de viés" se o estudo marcou menos de 10 no QUADAS (HEGEDUS et al., 2007; REIMAN; LOUDON; GOODE, 2013; WHITING et al., 2011) (Tabela 2).

\begin{tabular}{|c|c|c|c|c|}
\hline Item & & Yes & No & Unclear \\
\hline I. & Was the spectrum of patients representative of the patients who will receive the test in practice? & () & () & () \\
\hline 2. & Were selection criteria clearly described? & () & () & () \\
\hline 3. & Is the reference standard likely to correctly classify the target condition? & () & () & () \\
\hline 4. & $\begin{array}{l}\text { Is the time period between reference standard and index test short enough to be reasonably } \\
\text { sure that the target condition did not change between the two tests? }\end{array}$ & () & ( ) & () \\
\hline 5. & $\begin{array}{l}\text { Did the whole sample or a random selection of the sample, receive verification using a reference } \\
\text { standard of diagnosis? }\end{array}$ & ( ) & ( ) & () \\
\hline 6. & Did patients receive the same reference standard regardless of the index test result? & () & () & () \\
\hline 7. & $\begin{array}{l}\text { Was the reference standard independent of the index test (i.e. the index test did not form part of } \\
\text { the reference standard)? }\end{array}$ & () & () & () \\
\hline 8. & Was the execution of the index test described in sufficient detail to permit replication of the test? & () & () & () \\
\hline 9. & $\begin{array}{l}\text { Was the execution of the reference standard described in sufficient detail to permit its } \\
\text { replication? }\end{array}$ & () & () & () \\
\hline 10. & $\begin{array}{l}\text { Were the index test results interpreted without knowledge of the results of the reference } \\
\text { standard? }\end{array}$ & () & ( ) & () \\
\hline II. & $\begin{array}{l}\text { Were the reference standard results interpreted without knowledge of the results of the index } \\
\text { test? }\end{array}$ & () & () & () \\
\hline 12. & $\begin{array}{l}\text { Were the same clinical data available when test results were interpreted as would be available } \\
\text { when the test is used in practice? }\end{array}$ & () & ( ) & () \\
\hline 13. & Were uninterpretable/ intermediate test results reported? & () & () & () \\
\hline 14. & Were withdrawals from the study explained? & () & () & () \\
\hline
\end{tabular}

Fonte: Artigo original do QUADAS.

Figura 12 - Critérios originais da ferramenta de avaliação (QUADAS) dos artigos incluídos na revisão sistemática.

Tabela 2 - Avaliação do QUADAS para todos os artigos incluídos nessa revisão para identificar o risco de viés.

\begin{tabular}{|c|c|c|c|c|c|c|c|c|c|c|c|c|c|c|c|}
\hline Artigo & 1 & 2 & 3 & 4 & 5 & 6 & 7 & 8 & 9 & 10 & 11 & 12 & 13 & 14 & Total \\
\hline $\begin{array}{l}\text { (CUZZUBBO et al., } \\
1998)\end{array}$ & $\mathrm{Y}$ & $\mathrm{Y}$ & $\mathrm{Y}$ & $\mathrm{Y}$ & $\mathrm{Y}$ & $\mathrm{Y}$ & $\mathrm{Y}$ & $\mathrm{Y}$ & $\mathrm{N}$ & $U$ & $\mathrm{U}$ & $\mathrm{X}$ & $\mathrm{Y}$ & $\mathrm{Y}$ & 10 \\
\hline $\begin{array}{l}\text { (ARTIMOS DE } \\
\text { OLIVEIRA et al., 1999) }\end{array}$ & Y & Y & Y & Y & $\mathrm{Y}$ & Y & Y & Y & Y & $U$ & $U$ & $\mathrm{X}$ & Y & $\mathrm{Y}$ & 11 \\
\hline $\begin{array}{l}\text { (BALMASEDA et al., } \\
\text { 2003) }\end{array}$ & Y & Y & $\mathrm{Y}$ & Y & Y & Y & Y & Y & Y & $U$ & $U$ & $\mathrm{x}$ & Y & $\mathrm{Y}$ & 11 \\
\hline (YAP; SIL; NG, 2011) & Y & Y & $\mathrm{Y}$ & Y & Y & Y & Y & Y & Y & $\mathrm{N}$ & $\mathrm{Y}$ & $X$ & Y & $\mathrm{Y}$ & 12 \\
\hline (ANDERS et al., 2012) & Y & Y & Y & Y & Y & $\mathrm{N}$ & Y & Y & Y & U & U & $\mathrm{X}$ & Y & $\mathrm{Y}$ & 9 \\
\hline $\begin{array}{l}\text { (BALMASEDA et al., } \\
\text { 2008) }\end{array}$ & Y & Y & $\mathrm{Y}$ & $Y$ & $Y$ & $Y$ & $Y$ & $Y$ & $Y$ & U & $U$ & $X$ & $Y$ & $Y$ & 11 \\
\hline $\begin{array}{l}\text { (CHAKRAVARTI; } \\
\text { MATLANI; JAIN, 2007) }\end{array}$ & $Y$ & $Y$ & $Y$ & $Y$ & $Y$ & $\mathrm{~N}$ & $Y$ & $Y$ & $Y$ & $U$ & $U$ & $x$ & $Y$ & $Y$ & 10 \\
\hline
\end{tabular}

\subsubsection{Extração de dados}

A extração dos dados foi feita pelos mesmos dois autores de forma independente utilizando os métodos recomendados para a avaliação de teste de diagnóstico, são eles: autor, ano de publicação, país, tipo de amostra, tipo de coleta, 
padrão ouro, número de falsos positivos, verdadeiros positivos, falsos negativos e verdadeiros negativos para cálculo da sensibilidade, especificidade, razão de probabilidade positiva e negativa (DEVILLE et al., 2002).

2.11.2.1 Diagnóstico de Dengue e Imunoglobulina M (IgM)

A detecção de IgM, utilizando captura ELISA IgM em uma única amostra, atualmente é o método diagnóstico mais utilizado. No entanto, é um resultado "provável" em vez de "confirmado" para dengue, o que exige pares de marcadores ou detecção de vírus em uma amostra de fase aguda. A utilidade da saliva no diagnóstico sorológico da dengue foi estudado mostrando que IgM específica pode ser detectada em pacientes com infecção primária (POLONI et al., 2010; VAZQUEZ et al., 2007), e em pacientes com infecção secundária (VAZQUEZ et al., 2007), e ainda, pode persistir por mais de 8 meses após a infecção (CHEN; HWANG; FANG, 1991; CHOW; HSU, 1989; TALARMIN et al., 1998). Níveis de IgM salivar em infecções de vírus de dengue primária foram maiores do que os encontrados em infecções secundárias, enquanto que os níveis salivares de lgG foram geralmente maiores nas infecções secundárias (CUZZUBBO et al., 1998). Altas taxas de positividade foram observadas para as amostras de saliva colhidas após 5 dias do início da febre da dengue (ARTIMOS DE OLIVEIRA et al., 1999). Amostras de saliva obtidas após 10 dias $91,7-100,0 \%$ eram positivas (ARTIMOS DE OLIVEIRA et al., 1999). A positividade de amostras de saliva aumentou após os primeiros dias do início da dengue Nem todas infecções resultam em IgM detectável, até mesmo vários dias após a infecção (ARTIMOS DE OLIVEIRA et al., 1999). Resultados encontrados sintetizados na tabela 3 . 
Tabela 3 - Descrição dos resultados encontrados na utilização de IgM para diagnóstico da dengue na saliva.

\begin{tabular}{lcccccc}
\hline Autor, ano & TP & FP & FN & TN & SN & SP \\
\hline (CUZZUBBO et al., 1998) & 11 & 0 & 13 & 11 & 0.46 & 1.00 \\
(ARTIMOS DE OLIVEIRA et al., 1999) & 25 & 0 & 13 & 32 & 0.66 & 1.00 \\
(BALMASEDA et al., 2003) & 65 & 6 & 7 & 69 & 0.90 & 0.92 \\
(ANDERS et al., 2012) & 57 & 1 & 30 & 125 & 0.66 & 0.99 \\
(BALMASEDA et al., 2008) & 155 & 2 & 42 & 13 & 0.79 & 0.87 \\
(CHAKRAVARTI; MATLANI; JAIN, 2007) & 60 & 6 & 0 & 14 & 1.00 & 0.70 \\
\hline
\end{tabular}

TP: verdadeiro positivo; FP: falso positivo; FN: falso negativo; TN: verdadeiro negativo; SN: sensibilidade; SP: especificidade.

\subsubsection{Diagnóstico de Dengue e Imunoglobulina G (IgG)}

O uso de IgG salivar para diagnóstico e em estudos epidemiológicos foi descrito (BALMASEDA et al., 2008; CHAKRAVARTI; MATLANI; JAIN, 2007; CUZZUBBO et al., 1998), estudos mostraram que IgG específica pode ser detectada tanto em pacientes com infecção primária (POLONI et al., 2010) como em pacientes com infecção secundária (CUZZUBBO et al., 1998; VAZQUEZ et al., 2007). Algumas descobertas indicam que os níveis elevados de IgG podem indicar características da infecção por dengue secundária ou de infecções passadas por vírus de dengue mas não de infecção primária (CUZZUBBO et al., 1998). Portanto, em casos de infecção primária nos quais se aplicar o teste para imunoglobulina IgG salivar poderá ser obtido um resultado falso negativo. Resultados encontrados sintetizados na tabela 4.

Tabela 4 - Descrição dos resultados encontrados para utilização de IgG para diagnóstico da dengue na saliva.

\begin{tabular}{lcccccc}
\hline Autor, ano & TP & FP & FN & TN & SN & SP \\
\hline (CUZZUBBO et al., 1998) & 19 & 0 & 5 & 11 & 0.79 & 1.00 \\
(ARTIMOS DE OLIVEIRA et al., 1999) & 8 & 19 & 38 & 31 & 0.17 & 0.62 \\
(ANDERS et al., 2012) & 57 & 4 & 9 & 145 & 0.86 & 0.97 \\
(BALMASEDA et al., 2008) & 45 & 51 & 10 & 212 & 0.82 & 0.81 \\
(CHAKRAVARTI; MATLANI; JAIN, 2007) & 56 & 0 & 4 & 20 & 0.93 & 1.00 \\
(CUZZUBBO et al., 1998) & 19 & 0 & 5 & 11 & 0.79 & 1.00 \\
\hline
\end{tabular}

TP: verdadeiro positivo; FP: falso positivo; FN: falso negativo; TN: verdadeiro negativo; SN: sensibilidade; SP: especificidade. 
2.11.2.3 Diagnóstico de Dengue e Imunoglobulina A ( $\lg A)$

O ELISA de captura de IgA tem utilidade no diagnóstico da dengue, essa imunoglobulina aparece de forma mais lenta do que a $\operatorname{lgM}$, e desaparece mais rapidamente (TALARMIN et al., 1998). Uma configuração padrão de um ELISA de captura de IgA na saliva, aparentemente, não constitui um método muito útil para o diagnóstico de infecção por dengue, em comparação com o da IgM (BALMASEDA et al., 2003), no entanto, suas concentrações de anticorpos em saliva são muito maiores do que as de $\operatorname{lgM}(19,9 \mathrm{mg} / 100 \mathrm{ml}$ para IgA e $0,2 \mathrm{mg} / 100 \mathrm{ml}$ para IgM) (PARRY; PERRY; MORTIMER, 1987), por conseguinte, antes de rejeitar IgA salivar como biomarcador, foi investigada uma nova maneira de se identificar a IgA por meio de um ELISA específico (ACA-ELISA - método indireto) (BALMASEDA et al., 2003). A sensibilidade do ACA-ELISA foi de $95 \%$ para os pacientes que visitaram seus médicos até 6 dias após o início da febre. Além disso, ACA-ELISA IgA na saliva teve alta sensibilidade em infecções dengue secundária, portanto, esta técnica pode ser muito útil em áreas de alta epidemia, onde a maioria dos casos de dengue são secundários (YAP; SIL; NG, 2011). Embora represente uma maneira diferente de detectar o $\lg \mathrm{A}$, o biomarcador utilizado é o mesmo, por isso foram agrupados juntos, mas os dados devem ser interpretados com cuidado, uma vez que, o método empregado para identificação do IgA foi diferente nos trabalhos estudados entre si. Resultados encontrados sintetizados na tabela 5.

Tabela 5 - Descrição dos resultados encontrados para utilização de lgA para diagnóstico da dengue na saliva.

\begin{tabular}{lcccccc}
\hline Autor, ano & TP & FP & FN & TN & SN & SP \\
\hline (BALMASEDA et al., 2003) & 51 & 24 & 21 & 51 & 0.71 & 0.68 \\
(YAP; SIL; NG, 2011) & 172 & 1 & 35 & 74 & 0.83 & 0.99 \\
(BALMASEDA et al., 2008) & 50 & 0 & 24 & 80 & 0.68 & 1.00 \\
\hline
\end{tabular}

TP: verdadeiro positivo; FP: falso positivo; FN: falso negativo; TN: verdadeiro negativo; SN: sensibilidade; SP: especificidade.

\subsubsection{Diagnóstico de Dengue e Proteína Não Estrutural 1 (NS1)}

Recentemente, tanto o ELISA como os testes imunocromatográficos para a deteç̧ão de antígeno da dengue NS1 parecem ter boa especificidade para o 
diagnóstico precoce da dengue (HANG et al., 2009), o que ofereceu aos laboratórios uma ferramenta eficaz para o diagnóstico precoce durante a fase febril da doença (DUSSART et al., 2006; KUMARASAMY et al., 2007; POK et al., 2010; YOUNG et al., 2000). Resultados encontrado no único estudo sintetizado na tabela 6.

Tabela 6 - Descrição dos resultados encontrados para utilização de NS1 para diagnóstico da dengue na saliva

\begin{tabular}{lcccccc}
\hline Autor, ano & TP & FP & FN & TN & SN & SP \\
\hline (ANDERS et al., 2012) & 55 & 1 & 30 & 23 & 0.65 & 0.96 \\
\hline
\end{tabular}

TP: verdadeiro positivo; FP: falso positivo; FN: falso negativo; TN: verdadeiro negativo; SN: sensibilidade; SP: especificidade.

\subsubsection{Heterogeneidade dos dados}

Antes de realizar a combinação estatística (meta-análise) dos estudos, é fundamental avaliar a heterogeneidade que existe entre eles.

- Por que os resultados variaram entre os estudos?

- A variação foi ao acaso?

- A variação foi causada por diferenças metodológicas?

Os resultados dos trabalhos são diferentes entre si por alguns fatores importantes. No caso dos resultados dos diagnósticos, há variações entre dengue primária e dengue secundária. A infecção por dengue primária é caracterizada pela coleta nas primeiras 72 horas e os resultados tendem a ser melhores usando PCRRT e piores para detecção IgG por ELISA. A ausência de IgG na fase aguda de uma infecção por dengue é indicativa de infecção de dengue primária. A infecção secundária por dengue é caracterizada pelo fato de a amostra ser simultaneamente positiva no PCR-RT e IgG-ELISA (CORDEIRO et al., 2009; HALSTEAD, 2007). A sensibilidade de todos os diagnósticos da dengue dependem do tempo de infecção no qual foi coletada a amostra: na fase aguda (1 até 10 dias do início dos sintomas) ou fase convalescente (10 até 14 dias após inicio dos sintomas). Alguns estudos têm distinguido as infecções primárias das secundárias por meio de comparação entre os níveis de anticorpos $\lg$ e $\operatorname{lgG}$ em amostras de sangue (CHAKRAVARTI; MATLANI; JAIN, 2007). Da mesma forma, IgM e IgG salivar poderiam ajudar a 
diferenciar as infecções primárias das secundárias (LOLEKHA et al., 2004; SANG; CUZZUBBO; DEVINE, 1998; SANG et al., 1998; VAUGHN et al., 1998; VAZQUEZ et al., 2005).

Quando se está diante de um diagnóstico dicotômico (presença ou ausência de doença), os componentes da acurácia são a sensibilidade e a especificidade. É necessário lembrar-se de que um método precisa apresentar equilíbrio entre desses dois parâmetros. Sensibilidade é a capacidade do método em reconhecer os doentes, enquanto especificidade é a capacidade do método em reconhecer os saudáveis. É fundamental discriminar os doentes dos saudáveis, portanto precisa-se tanto de sensibilidade como de especificidade. É fácil simular a invenção de um método $100 \%$ sensível: é só dizer que toda a população é doente. Porém nesse caso a especificidade será $0 \%$, ou seja, nenhum saudável será reconhecido como tal, logo, esse método não serve para nada. Não discrimina nada. Daí surge a importância de se pensar sempre nos dois parâmetros conjuntamente. Por isso, se na meta-análise juntarmos os dois parâmetros (sensibilidade e especificidade) ficará inapropriadas, pois pode omitir dados importantes (HONEST; KHAN, 2002).

\subsubsection{Resultados}

Uma forma mais eficiente de demonstrar a relação normalmente antagônica entre a sensibilidade e a especificidade dos exames que apresentam resultados contínuos são as Curvas de Características de Operação do Receptor (Curvas ROC- Receiver Operating Characteristic). A Curva ROC é uma ferramenta poderosa para medir e especificar problemas no desempenho do diagnóstico em medicina e por permitir estudar a variação da sensibilidade e especificidade para diferentes valores de corte. Os resultados dos diferentes marcadores para diagnóstico da dengue na saliva foram descritos usando essa curva (Figura 13, Figura 14 e Figura 15).

Análise estatística: a razão preditiva positiva, a razão preditiva negativa e seu intervalo de confiança (IC) de $95 \%$ foram calculados usando um modelo de 
efeitos fixos de acordo com o método de Mantel-Haensed e Der Simonian e Laird (DERSIMONIAN; LAIRD, 1986; GALLAGHER, 1998).

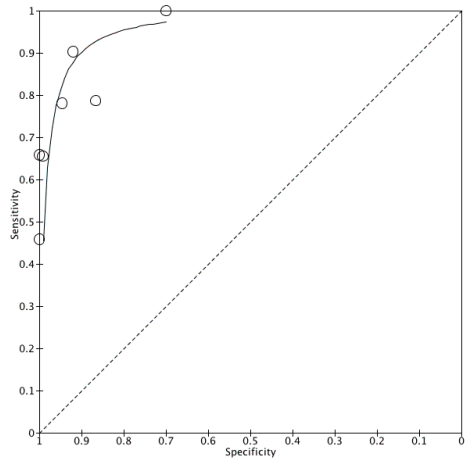

Figura 13 - Curva ROC dos trabalhos utilizando saliva e lgM para diagnóstico da dengue.

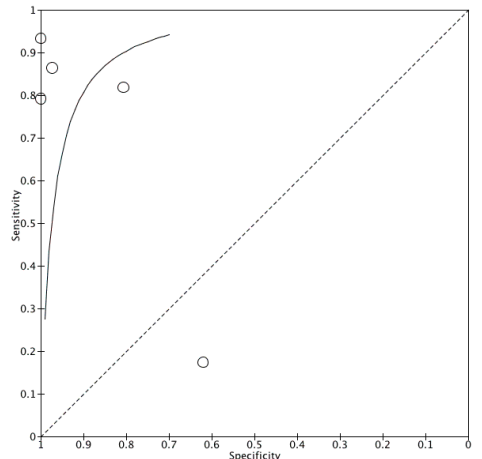

Figura 14 - Curva ROC dos trabalhos utilizando saliva e IgG para diagnóstico da dengue.

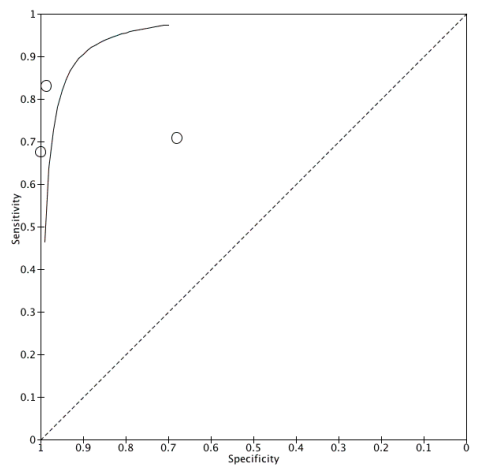

Figura 15 - Curva ROC dos trabalhos utilizando saliva e IgA para diagnóstico da dengue.

Os resultados indicaram que, na saliva, o teste de detecção de $\lg M$ e $\lg A$ se mostraram confiáveis para o diagnóstico da dengue (Tabela 7). No entanto, 0 teste de avaliação da NS-1 demonstrou ser mais específico na saliva, sua baixa sensibilidade pode ter ocorrido em função de ser a menor amostra. Além disso, a saliva pode potencialmente substituir o sangue como o fluído corporal de escolha para diagnóstico de dengue. O diagnóstico da dengue usando saliva pode fornecer informações quanto à prevalência e distribuição da dengue, o que pode ser utilizado 
para medidas de biossegurança e para a melhoria das estratégias de controle de doenças.

Tabela 7 - Meta-análise da sensibilidade e especificidade dos estudos incluídos.

\begin{tabular}{lll}
\hline Biomarcador & Sensibilidade & Especificidade \\
\hline $\operatorname{lgM}$ & $0,78(95 \% \mathrm{Cl} 0,74-0,82)$ & $0,95(95 \% \mathrm{Cl} 0,91-0,97)$ \\
$\operatorname{lgG}$ & $0,74(95 \% \mathrm{Cl} 0,68-0,79)$ & $0,85(95 \% \mathrm{Cl} 0,82-0,88)$ \\
$\operatorname{lgA}$ & $0,77(95 \% \mathrm{Cl} 0,73-0,82)$ & $0,89(95 \% \mathrm{Cl} 0,84-0,93)$ \\
NS1 & $0,65(95 \% \mathrm{Cl} 0,54-0,75)$ & $0,96(95 \% \mathrm{Cl} 0,79-1,00)$ \\
\hline
\end{tabular}

\subsection{JUSTIFICATIVA E APLICABILIDADE AO SUS}

A Dengue é um grande problema de saúde pública no Brasil. A maneira mais eficiente de combatê-la é eliminar criadouros do mosquito A. Aegypti, que é seu principal vetor no Brasil. Os criadouros são localizados por meio da confirmação laboratorial da dengue, a qual aciona as equipes de controle de vetores. Logo, quanto mais rápido o diagnóstico, mais rápida a identificação dos focos e mais rápida é a eliminação dos criadouros. Cada mosquito bota em torno de 100 ovos, os quais levam apenas 7 dias para evoluir para sua forma alada (ou seja, adulta). Portanto, se for possível diminuir alguns dias no combate do foco, pode ser possível diminuir significativamente a quantidade de mosquitos. Neste trabalho mostramos uma forma mais rápida de se obter confirmações laboratoriais da dengue. Além disso, utilizamos para o diagnóstico, amostras de saliva, as quais podem ser obtidas facilmente por não requererem pessoal especializado para sua coleta, além de descartar a necessidade da punção, principalmente em bebês, crianças, pessoas com necessidades especiais, alguns religiosos, pessoas com medo de agulha, pessoas com discrasias sanguíneas e outros. Assim, o método de coleta de saliva pode representar ao SUS uma economia financeira, agilizar a logística para coleta de amostras, aumentar a adesão de doentes para confirmação laboratorial e viabilizar trabalhos epidemiológicos para monitoramento da doença no Brasil. 


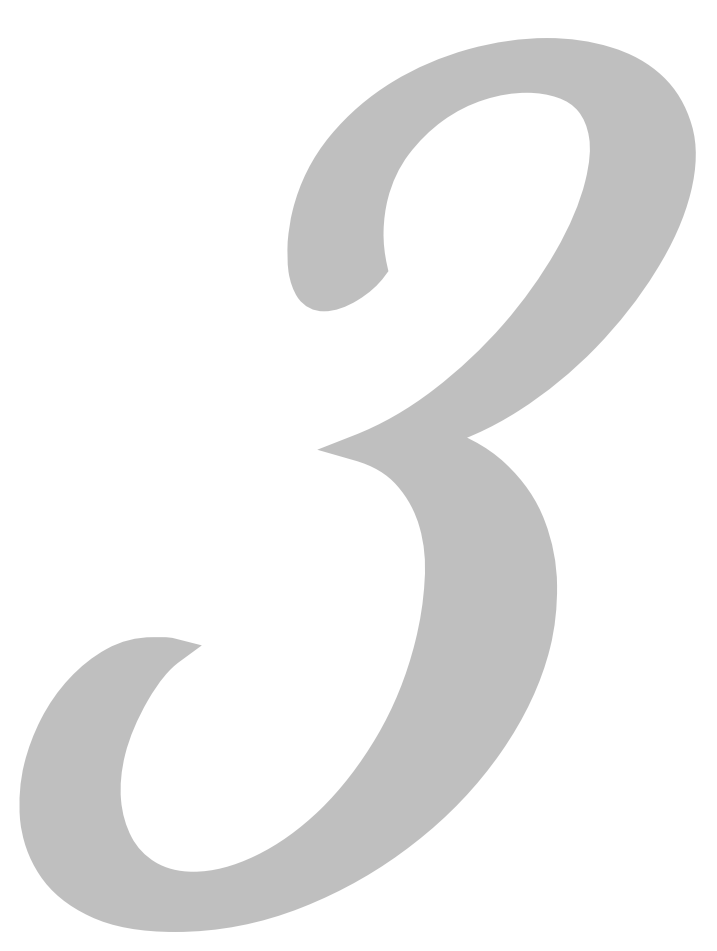

Proposição

"Se você pode sonhar, você pode fazer." Walt Disney 



\section{PROPOSIÇÃO}

O objetivo deste trabalho foi avaliar a utilização da saliva no diagnóstico da dengue, esclarecendo algumas dúvidas:

Hipótese alternativa (H1)

1. Identificar RNA viral em amostras de saliva de pacientes infectados com dengue durante o período febril.

2. Avaliar o teste rápido para identificar NS1 em amostra de saliva.

3. Identificar a presença de NS1 em amostras de saliva por meio do teste ELISA.

Hipótese nula (HO):

1. É possível encontrar o vírus dengue presente em amostras de saliva de pacientes infectados com dengue.

2. É possível identificar a NS-1 em amostras de saliva utilizando o teste imunocromatográfico.

3. É possível dosar a quantidade de NS-1 em amostras de saliva utilizando o teste ELISA. 




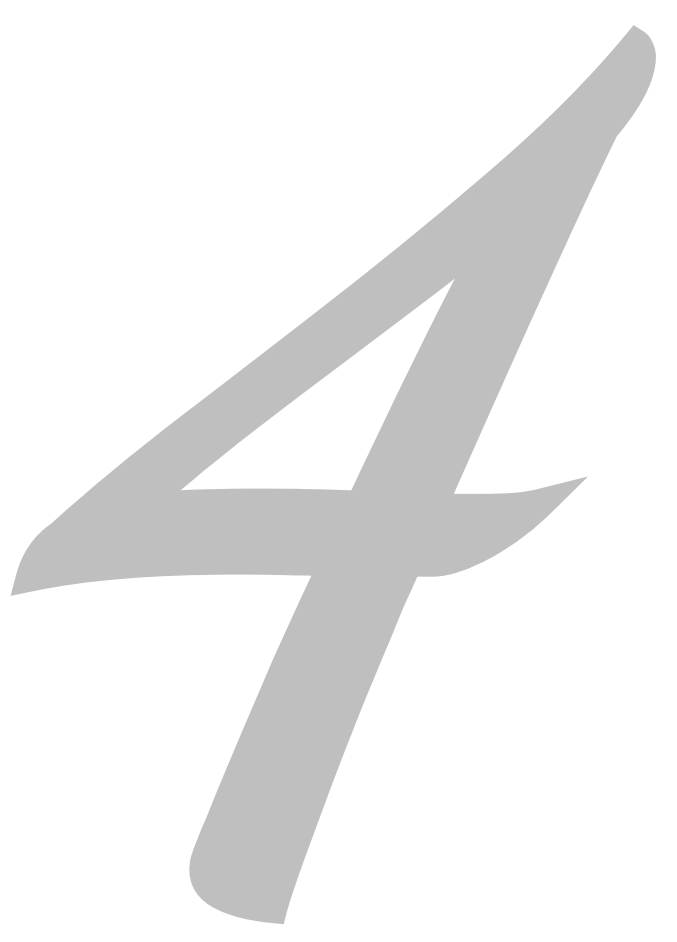

Material e M(étodos

"Somente os que ousam muito, podem realizar muito." John F. Kennedy 




\section{MATERIAL E MÉTODOS}

\subsection{ASPECTOS ÉTICOS}

Inicialmente o projeto foi enviado aos Comitês de Ética em Pesquisa da Faculdade de Odontologia de Bauru - Universidade de São Paulo, do Hospital Estadual de Bauru dos quais foi obtida a aprovação e solicitação de autorização para realização em Bauru pela Secretaria Municipal de Saúde de Bauru a qual também foi concedida.

\subsection{RECRUTAMENTO DOS SUJEITOS DA PESQUISA}

Os pacientes que procurassem o serviço de atendimento do Hospital Estadual de Bauru (HEB) e a Unidade de Pronto Atendimento Vila Ipiranga, Bauru SP (UPA), com suspeita de diagnóstico clínico para dengue, foram convidados a participar da pesquisa e uma vez aceito, assinavam o termo de consentimento livre e esclarecido.

Seguindo os critérios adotados pela Organização Mundial da Saúde e do Ministério da Saúde, definiu-se como caso suspeito de dengue todo indivíduo que apresentasse febre alta $\left(39^{\circ}\right.$ a $\left.40^{\circ} \mathrm{C}\right)$, até o décimo dia de inicio deste sintoma, e pelo menos mais dois dos sintomas clínicos tais como: cefaleia, mialgia, prostração, artralgia, astenia, anorexia, dor retro-orbital, náuseas, vômitos, exantema e prurido cutâneo.

Foram excluídos da amostra dessa pesquisa:

- Mulheres grávidas;

- Portadores de doenças reumatoides;

- Pacientes que tomaram vacina de gripe.

\subsection{AMOSTRAS CLÍNICAS}

Esse foi um estudo prospectivo para o qual foram convidados a participar 44 indivíduos que preencheram os critérios para casos suspeitos de dengue, 
residentes na cidade de Bauru - SP e que receberam atendimento no Hospital Estadual de Bauru ou na Unidade de Pronto Atendimento da Vila Ipiranga, no período de Junho de 2012 a Fevereiro de 2013. A idade média dos participantes foi de 34 anos, o mais novo tinha 13 anos e o mais idoso 65 anos. Vinte e seis mulheres $(59 \%)$ e dezoito homens $(41 \%)$ compuseram o grupo de participantes.

\subsection{COLETA DAS AMOSTRAS DE SALIVA NÃO ESTIMULADA}

Os dois postos de coleta foram o Hospital Estadual de Bauru e a Unidade de Pronto Atendimento Vila Ipiranga onde é realizado o diagnóstico clínico da dengue, e coletada amostra de sangue para realização da sorologia. Neste mesmo momento, foi realizada a coleta de saliva em 44 indivíduos.

Foi coletada saliva não estimulada, pois apresenta uma maior participação das glândulas sublingual e submandibular e contém uma maior quantidade de fluido sulcular gengival, o qual é responsável por quase a totalidade dos componentes sanguíneos presentes na saliva. Dessa forma, a saliva não estimulada contém uma variedade de proteínas diferentes entre si, com funções biológicas específicas que são diferentes em composição e função. A coleta foi realizada seguindo o protocolo de SIQUEIRA (SIQUEIRA; DAWES, 2011), o qual é descrito a seguir:

a. Explicar o procedimento de coleta de saliva para o sujeito de pesquisa e assinatura do termo de consentimento livre e esclarecido.

b. A coleta é feita com o paciente confortavelmente sentado em uma cadeira em uma sala bem ventilada e iluminada (Figura 16).

c. Utilização de luvas descartáveis e limpas para inserir a ponta do tubo de sucção no adaptador para o tubo de coleta (Figura 17).

d. O tubo de coleta foi colocado no gelo picado.

e. Foi documentado o horário de início da coleta.

f. A extremidade livre da ponta da coleta deverá ser colocada na boca do indivíduo, passando por todos os pontos possíveis da cavidade bucal para a aspiração da saliva. Como a saliva coletada é não estimulada, é importante que o sujeito de pesquisa não mastigue a ponta de sucção, para não haver estimulo de fluxo salivar. 
g. A coleta terminará se o indivíduo estiver desconfortável ou ao se atingir $1,5 \mathrm{~mL}$.

h. Foi documentado o horário final da coleta.

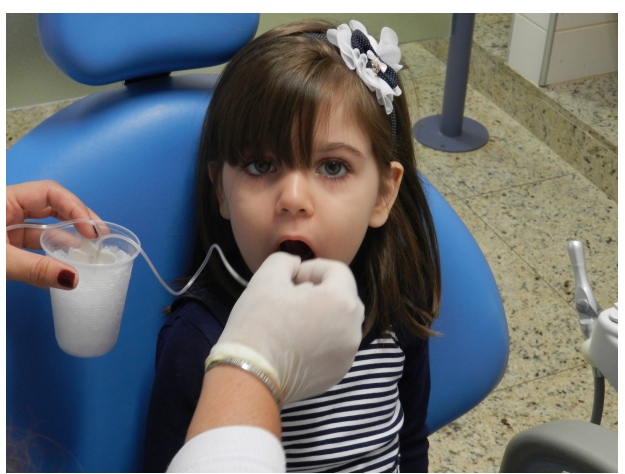

Figura 16 - Foto do procedimento de coleta na realização do estudo piloto.

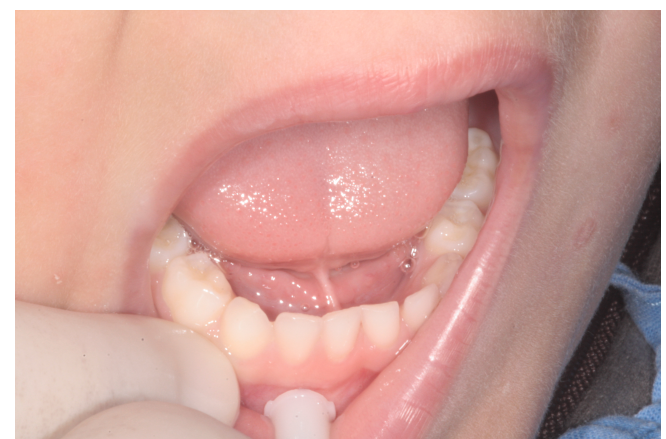

Figura 17 - Ponta de sucção ligada à bomba vácuo.

Os tubos foram mantidos no gelo com o código de identificação de cada sujeito de pesquisa para a realização do transporte até o laboratório da disciplina de Odontopediatria da Faculdade de Odontologia de Bauru - Universidade de São Paulo onde as amostras foram processadas, armazenadas e congeladas em tubos de $2,0 \mathrm{~mL}$ a $-80^{\circ} \mathrm{C}$ (Figura 18). Com relação aos métodos, é importante ressaltar que o congelamento de proteínas não interfere com a medição dos níveis de proteína.

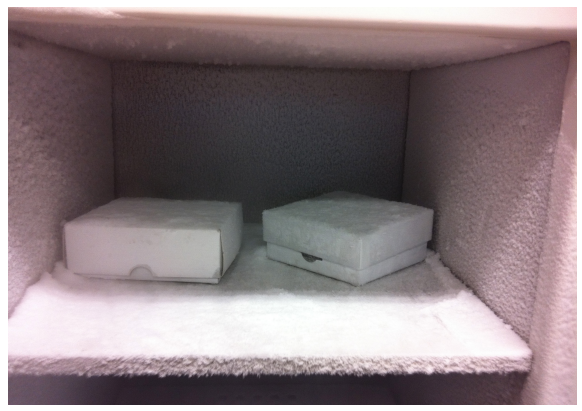

Figura 18 - Armazenamento das amostras a $-80^{\circ} \mathrm{C}$. 


\subsection{IDENTIFICAÇÃO DAS AMOSTRAS}

Em busca de uma solução para a organização, gerenciamento, manutenção, sigilo e disponibilidade de dados, foi desenvolvida a identificação das amostras de saliva coletadas por meio de códigos de barras (Figura 19), com informações sobre elas armazenadas num banco de dados. A Bioinformática permite criar bancos de dados que facilitam o armazenamento de dados biológicos, como o NCBI e GenBank. Essas ferramentas podem ajudar os pesquisadores a ter mais clareza sobre a autenticidade, legitimidade e confiabilidade em uma análise.

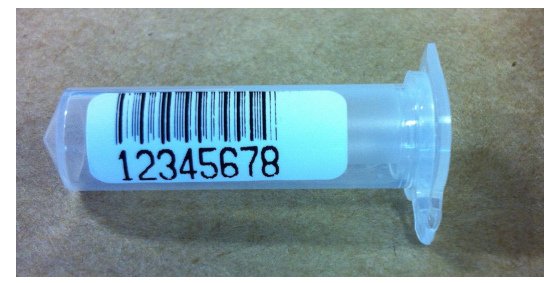

Figura 19 - Tubo identificado com código de barras.

Neste trabalho, foi desenvolvido e implementado um banco de dados que está hospedado no servidor da Faculdade de Odontologia de Bauru - Universidade de São Paulo. Esse banco de dados contém informações como: nome do paciente, sexo, idade, quantidade de saliva coletada, informações clínicas sobre a doença, cópia do termo de consentimento livre e esclarecido (Figura 20).

\begin{tabular}{|c|c|c|c|c|c|c|c|c|c|c|c|}
\hline \multicolumn{2}{|c|}{ Logado Como Gabriel Salles Barbério Log Out } & \multicolumn{2}{|c|}{ Imprimir esta página } & \multicolumn{3}{|c|}{ Imprimir todas as Páginas } & Busca Avancada & Importar & \multicolumn{3}{|c|}{ Exportar os Resultados } \\
\hline \multicolumn{12}{|c|}{\begin{tabular}{ll|} 
Projeto Dengue & Auditioria \\
\end{tabular}} \\
\hline Buscar & $a \quad \approx \quad \approx$ & & & & & & Itens & contrados: $26 \mathrm{Pe}$ & gina 1 de 2 Reg & istros por Página: & 20 \\
\hline Adicionar Novo & Elimina Selecionados & \multicolumn{2}{|c|}{ Exportação selecionada } & \multicolumn{3}{|c|}{ Impressão selecionada } & & & & & \\
\hline - $\frac{\text { Codigo de }}{\text { barra }}$ & Nome do paciente & Idade $\frac{\text { Telefone }}{\text { primário }}$ & $\frac{\text { Falar }}{\text { com }}$ & $\frac{\text { Data da }}{\text { coleta }}$ & $\frac{\text { Local da }}{\text { coleta }}$ & $\begin{array}{l}\text { Teve } \\
\text { febre? }\end{array}$ & $\begin{array}{l}\text { Quantos m/s foram } \\
\text { coletados? }\end{array}$ & $\frac{\text { Fez exame de }}{\text { sangue? }}$ & $\frac{\text { Fez prova do }}{\text { laco? }}$ & $\begin{array}{l}\text { Última } \\
\text { alteraçä́o por }\end{array}$ & $\frac{\text { Data da última }}{\text { alteracăo }}$ \\
\hline$\square, \square 4$ & & 65 & & & $\begin{array}{l}\text { UPA Vila } \\
\text { Ipiranga }\end{array}$ & Sim & 1,0 & & sim & $\begin{array}{l}\text { Gabriel Salles } \\
\text { Barbério }\end{array}$ & 21/03/2013 \\
\hline a $\quad 045$ & & 25 & & 20/02/2013 & $\begin{array}{l}\text { UPA Vila } \\
\text { Ipiranga }\end{array}$ & Sim & 0,0 & & & $\begin{array}{l}\text { Gabriel Salles } \\
\text { Barbério }\end{array}$ & $21 / 03 / 2013$ \\
\hline$\theta \square 46$ & - & $17-$ & - & 20/02/2013 & $\begin{array}{l}\text { UPA Vila } \\
\text { Ipiranga }\end{array}$ & Sim & 1,0 & & Sim & $\begin{array}{l}\text { Gabriel Salles } \\
\text { Barbério }\end{array}$ & 21/03/2013 \\
\hline$[0] \square 47$ & $\begin{array}{l}\text { Samuel aparecido Ferreiro } \\
\text { de Deus }\end{array}$ & $22-$ & - & 20/02/2013 & $\begin{array}{l}\text { UPA Vila } \\
\text { Ipiranga }\end{array}$ & Sim & 1,0 & & & $\begin{array}{l}\text { Gabriel Salles } \\
\text { Barbério }\end{array}$ & 21/03/2013 \\
\hline$\left[\begin{array}{ll}\square & \square 8\end{array}\right.$ & - & $65-$ & - & 20/02/2013 & $\begin{array}{l}\text { UPA Vila } \\
\text { Ipiranga }\end{array}$ & Sim & 1,0 & & & $\begin{array}{l}\text { Gabriel Salles } \\
\text { Barbério }\end{array}$ & $21 / 03 / 2013$ \\
\hline 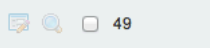 & Ariane & $19-$ & - & 20/02/2013 & $\begin{array}{l}\text { UPA Vila } \\
\text { Ipiranga }\end{array}$ & Sim & 1,0 & & & $\begin{array}{l}\text { Gabriel Salles } \\
\text { Barbério }\end{array}$ & $21 / 03 / 2013$ \\
\hline$Q 50$ & $\begin{array}{l}\text { Helena Therezinha de } \\
\text { Almeida }\end{array}$ & $54-$ & - & 20/02/2013 & $\begin{array}{l}\text { UPA Vila } \\
\text { Ipiranga }\end{array}$ & Sim & 0,0 & & & $\begin{array}{l}\text { Gabriel Salles } \\
\text { Barbério }\end{array}$ & 15/04/2013 \\
\hline$\left[\begin{array}{lll}0 & 0\end{array}\right.$ & Angélica & 3332762421 & - & $20 / 02 / 2013$ & $\begin{array}{l}\text { UPA Vila } \\
\text { Ipiranga }\end{array}$ & Sim & 0,0 & & Sim & $\begin{array}{l}\text { Gabriel Salles } \\
\text { Barbério }\end{array}$ & $21 / 03 / 2013$ \\
\hline$[Q 0 \quad 052$ & & 18 & & $22 / 02 / 2013$ & $\begin{array}{l}\text { UPA Vila } \\
\text { Ipiranga }\end{array}$ & Sim & & Não & Sim & $\begin{array}{l}\text { Gabriel Salles } \\
\text { Barbério }\end{array}$ & $02 / 04 / 2013$ \\
\hline$\square \quad 053$ & & 26 & & 22/02/2013 & $\begin{array}{l}\text { UPA Vila } \\
\text { Ipiranga }\end{array}$ & Sim & 0,0 & & Sim & $\begin{array}{l}\text { Gabriel Salles } \\
\text { Barbério }\end{array}$ & $15 / 04 / 2013$ \\
\hline$\square \bigcirc \square 54$ & & 27 & & $22 / 02 / 2013$ & $\begin{array}{l}\text { UPA Vila } \\
\text { Ipiranga }\end{array}$ & Sim & 1,0 & & Sim & $\begin{array}{l}\text { Gabriel Salles } \\
\text { Barbério }\end{array}$ & 15/04/2013 \\
\hline
\end{tabular}

Figura 20 - Banco de dados com alguns dados das amostras coletadas. 


\subsection{PROCESSAMENTO DAS AMOSTRAS DE SALIVA}

As confirmações laboratoriais do diagnóstico da dengue foram feitas com amostras de soro, com base nos testes de ELISA de captura para lgM/lgG, coletadas pelas próprias enfermeiras dos locais onde os pacientes estavam sendo atendidos e encaminhadas para os laboratórios especializados neste tipo de diagnóstico, no serviço público de Bauru - SP.

As amostras de saliva foram processadas no laboratório de Farmacologia da Faculdade de Odontologia de Bauru - Universidade de São Paulo.

\subsubsection{Reação em Cadeia da Polimerase em Tempo Real (PCR-RT)}

A reação em cadeia da polimerase em tempo real (PCR-RT) foi desenvolvida para detectar o RNA em amostras humanas. Essa técnica é uma importante ferramenta para o diagnóstico da infecção pelo vírus da dengue. Foram realizadas as PCR-RT para identificação do vírus da dengue (e seus sorotipos: 1, 2, 3 e 4) na saliva durante a infecção aguda da dengue de 10 pacientes, todos com diagnóstico confirmado pela sorologia de lgM/lgG. Toda a metodologia realizada nesse trabalho foi feita seguindo as instruções dos fabricantes
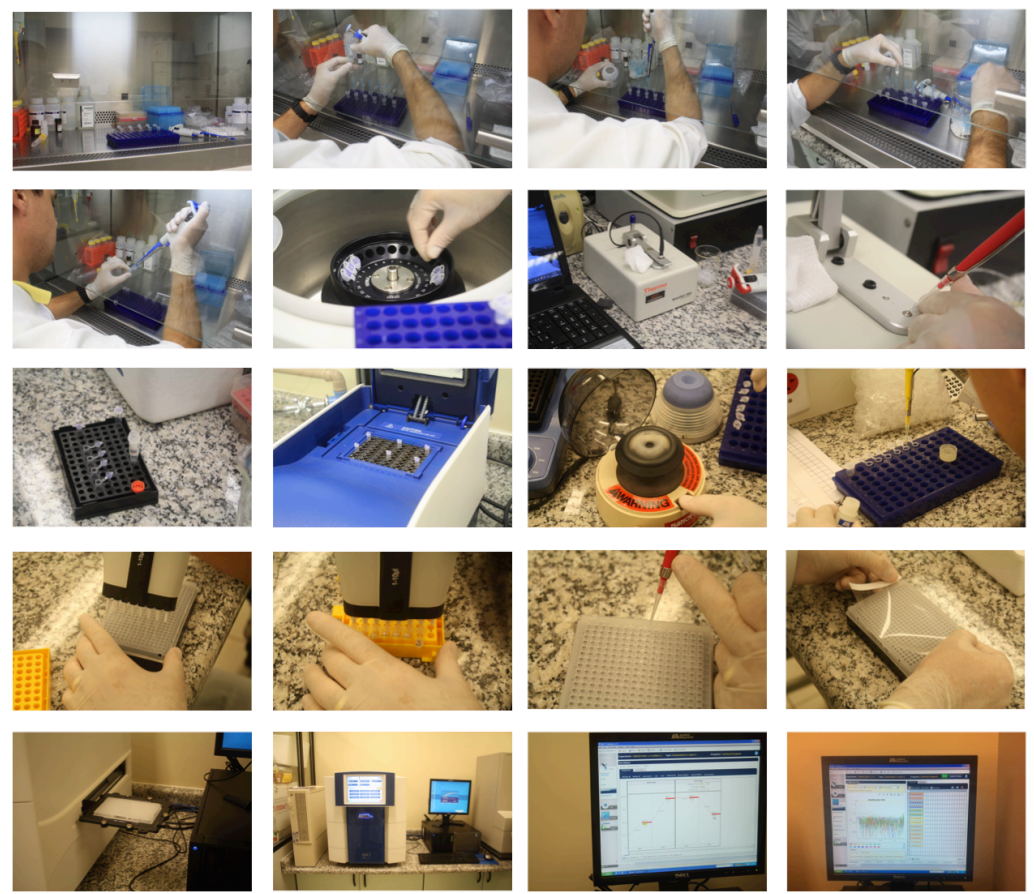

Figura 21 - Panorâma geral de todo o protocolo para realização do PCR-RT demostrando como é trabalhoso, demorado e requer prática laboratorial para realiza-lo. 


\subsubsection{Extração de RNA}

O RNA viral foi purificado a partir de $140 \mu$ da saliva dos pacientes utilizando o QIAamp® Viral RNA Mini Kit (QUIAGEN $®$, Alemanha), conforme protocolo recomendado pelo fabricante. As amostras foram transferidas do ultra freezer $-80^{\circ} \mathrm{C}$ para um isopor com gelo picado para que as amostras fossem lentamente aumentando sua temperatura até atingir $4^{\circ} \mathrm{C}$. Os materiais para extração do RNA do DENV foram assim distribuídos: Buffer AVL, Buffer AW1, Buffer AW2, Álcool absoluto.

Dentro do fluxo laminar, 6 amostras foram organizadas inicialmente em um rack e acrescentada a um tubo falcon no qual colocou-se Buffer AVL (480 mL) com auxílio de uma pipeta fazendo quatro colocações de $100 \mathrm{~mL}$ e uma de $48 \mathrm{~mL}$, utilizou-se uma medida suficiente para 8 amostras para compensar eventual falta de material. Neste mesmo tubo acrescentou-se ainda o Carrier RNA.

Em seguida no tubo falcon foi adicionado 44.8uL de 310 AVE + Carrier RNA. Em um novo eppendorf, para cada amostra, adicionou-se $140 \mu \mathrm{L}$ de amostra mais $560 \mu \mathrm{L}$ da mistura. Em seguida cada novo epeendorf foi agitado em vórtex por 15 segundos e deixado em repouso por 10 minutos para que a solução conseguisse efetivamente quebrar as paredes do vírus. Centrifugou-se a $9 \mathrm{rpm}$ por 1 minuto a $22^{\circ} \mathrm{C}$

Após a centrifugação, foi adicionado álcool absoluto $560 \mu \mathrm{M}$ diretamente sobre as amostras, pois o álcool é capaz de desidratar a amostra, o que aumenta a afinidade pela coluna que filtrará o RNA nos próximos passos. Foi realizada agitação em vórtex por 15 segundos e em centrífuga pequena.

Retirou-se, então, $630 \mu \mathrm{L}$ para o eppendorf com a coluna (filtro), fornecido pela empresa. Nessa etapa, a amostra deve ser despejada sobre a coluna. Após receber a mistura de $630 \mu \mathrm{L}$, o tubo com a coluna foi colocado na centrífuga grande a 8000 rpm por 1 minuto, lembrando-se sempre de balancear a centrífuga. Para retirálo da centrífuga é necessário extremo cuidado para que o que já foi filtrado não toque o filtro e não contamine. Retirou-se o filtro do eppendorf centrifugado, o qual foi colocado em um novo tubo, no qual foi adicionado também $500 \mu \mathrm{L}$ de Buffer AW1 para lavar e foi, então, retornado para a centrífuga com a mesma configuração anterior. 
4.6.1.2 Quantificação e qualificação do RNA total

A concentração de RNA total nas amostras foi determinada por meio de um espectofotômetro NanoDrop 1000 (Thermo Scientific, EUA) (Figura 22). Esse equipamento de posse de dois valores de abrangência, 260 e $280 \mathrm{~nm}$, fornece a quantidade $(\mathrm{ng} / \mu \mathrm{L})$ e qualidade do RNA total. A garantia de uma boa qualidade de RNA total é quando a razão entre as absorbâncias 260 e 280 nm está entre 1,9 e $2,1$.

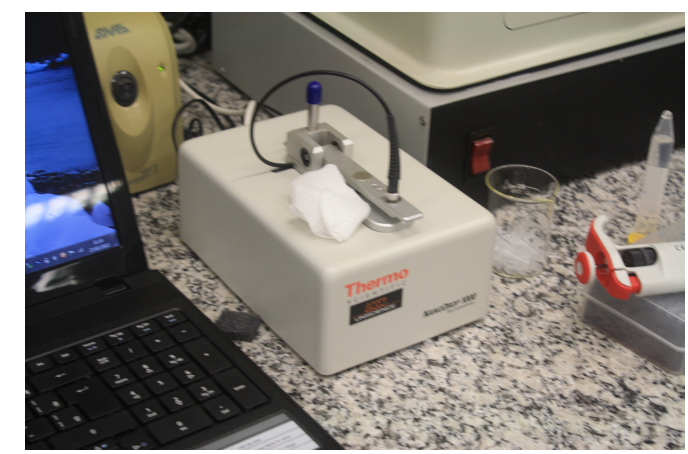

Figura 22 - Análise do RNA viável.

\subsubsection{Transcrição reversa (RNA em cDNA):}

Foi utilizado $1 \mu \mathrm{g}$ de RNA total para a transcrição em DNA complementar (cDNA) por meio da enzima transcriptase reversa (Kit de transcrição reversa, Invitrogen $®$, EUA). Em seguida foram adicionados os primers e sondas TaqMan®. A quantificação do mRNA foi realizada em uma única etapa (37) dessa forma, todos os reagentes necessários são misturados: dNTP, tampão, transcriptase reversa (RT), o par de primers complementares ao mRNA alvo e Taq DNA polimerase. Essa mistura contém concentrações ótimas de todos os componentes necessários para a síntese de cDNA e amplificação em um tubo de 0,2 $\mu \mathrm{L}$. Cada tubo dessa mistura contém um estabilizador. Assim, a mistura pode ser usada facilmente por simples distribuição do mix de $15 \mu \mathrm{L}$ de primer diluído em cada tubo, seguido da adição de $5 \mu \mathrm{L}$ de modelo de RNA (aproximadamente 1,0 mg). Esse mix de primer foi preparado misturando-se 400nM de primer e 200 nM de cada primer invertida (D1, D2, D3 e D4), com volume apropriado de água destilada. O perfil de ciclagem térmica deste ensaio consiste em um passo RT $30 \mathrm{~min}$, que é realizado a $50^{\circ} \mathrm{C}, 15 \mathrm{~min}$ de Taq ativação da polimerase a $95^{\circ} \mathrm{C}$, seguido de 40 ciclos de PCR a $95^{\circ} \mathrm{C}$ para desnaturação com 30 s cada ciclo, $60^{\circ} \mathrm{C}$ de recozimento por 30 s e $72^{\circ} \mathrm{C}$ de extensão por 1 min (Figura 23). Os primers 
utilizados nesse trabalho foram como descrito no artigo de Hue et al. 2011 (HUE et al., 2011).

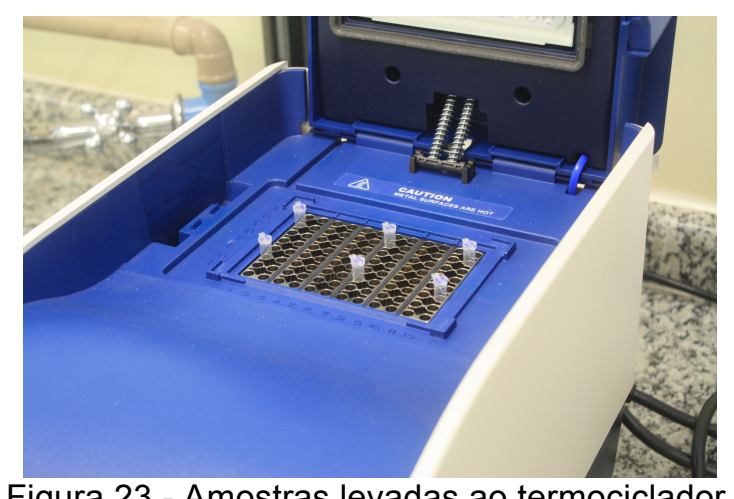

Figura 23 - Amostras levadas ao termociclador.

\subsubsection{Transcrição reversa (RNA em cDNA):}

A quantificação da expressão de RNAm foi realizada por meio do RealTime PCR, utilizando-se o sistema SYBRGreen (Invitrogen $\circledast$, EUA) em um aparelho Viia7 (Applied Biosystems, EUA) (Figura 24). Para todas as reações de Real-Time PCR, foram utilizados 2,5 $\mu \mathrm{L}$ do reagente SYBGreen Master Mix (Invitrogen®, EUA), $1 \mu \mathrm{L}$ do $\mathrm{cDNA}, 1 \mu \mathrm{L}$ dos primers e $0,5 \mu \mathrm{L}$ de água ultrapura. Uma amostra negativa (água) foi submetida à reação com cada par das sequências dos primers utilizados para garantir a não contaminação da reação.

Os resultados foram analisados com base no valor de CT (cicle threshold ou ciclo limiar), ponto correspondente ao número de ciclos em que a amplificação atinge o limiar exponencial da PCR, permitindo a análise quantitativa do nível de expressão do fator avaliado.

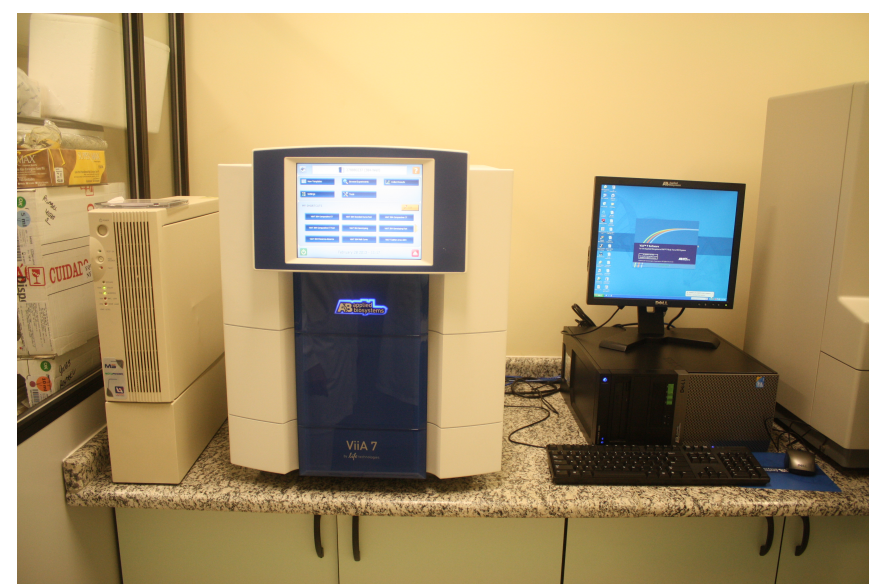

Figura 24 - Amostras prontas para análise da PCR-RT no Viia7. 


\subsubsection{Teste Imunocromatográfico para NS1 Ag Strip (teste rápido)}

Para o processamento das amostras de saliva, foi utilizado o teste dengue NS1 Ag STRIP ${ }^{T M}$ (Bio-Rad Laboratories, França), o qual é um teste imunocromatográfico para a detecção rápida do antígeno NS1 em plasma e, novamente, utilizou-se esse teste para detecção em saliva. Seguindo as instruções do fabricante, em um tubo de vidro ou de plástico com altura superior a $45 \mathrm{~mm}$ e um diâmetro inferior a $15 \mathrm{~mm}$, foi colocada uma gota do tampão de migração (que acompanha o teste) e $50 \mu \mathrm{L}$ de saliva, em seguida colocou-se a tira na posição vertical no interior do tubo (Figura 23).

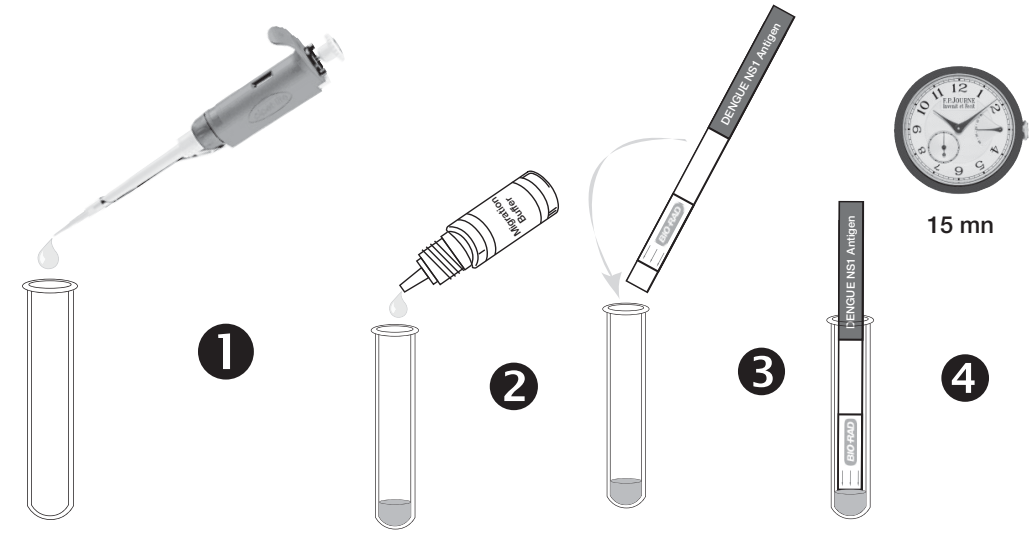

Figura 25 - Etapas para realização do teste imunocromatográfico NS1 Ag Stip.

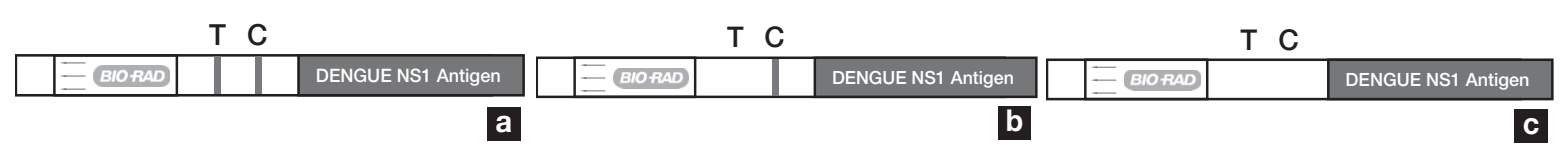

Figura 26 - Figura ilustrativa das tiras utilizadas no teste imunocromatográfico NS1 e seus possíveis resultados.

A tira tem duas linhas: uma linha controle (C) e uma linha de teste (T). A amostra deve migrar ao longo da tira e os resultados devem ser lidos ao fim de 15 minutos e ao fim de 30 minutos de migração. Quando presente na amostra, o antígeno NS1 liga-se aos anticorpos anti-NS1 fixados nas partículas de ouro coloidal e há o aparecimento das linhas $T$ e $C$, resultado positivo (Figura 24a). O aparecimento somente da linha $C$ indica resultado negativo, mas que o teste está funcionando (Figura 24b). Independentemente do estado do paciente, a Linha de 
Controle deve mostrar uma coloração azul ou violeta, se essa não aparecer o teste será considerado inválido. Recomenda-se que as tiras com cores duvidosas (cor fraca na linha T ou ausência de linhas - Figura 24c) ou resultados negativos sejam colocados de volta no tubo por mais 15 minutos para reavaliação.

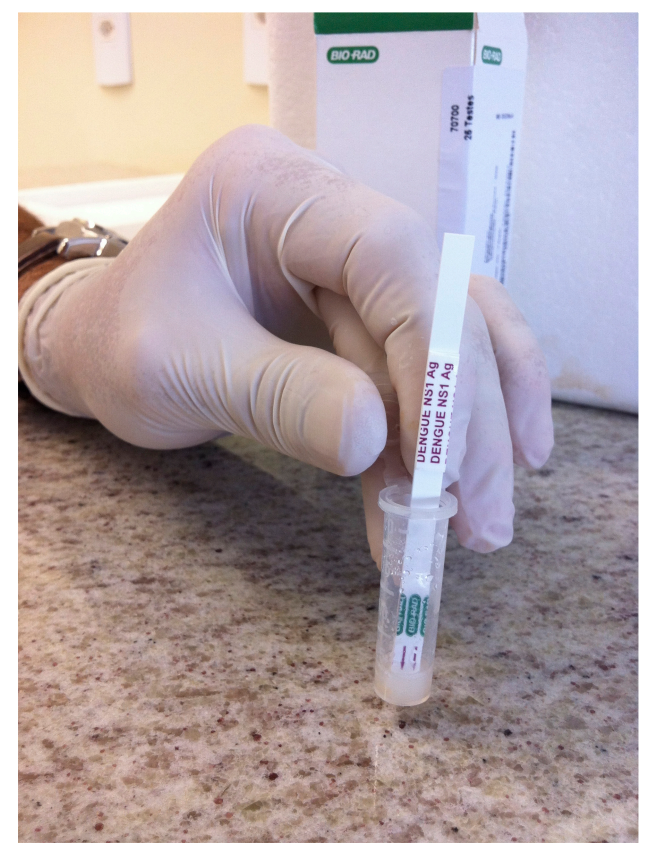

Figura 27 - Tira para diagnóstico de dengue sendo utilizado em amostra de saliva.

\subsubsection{Teste ELISA para NS1}

As 44 amostras de saliva coletadas foram submetidas ao teste ELISA NS1, para a detecção da proteína NS1. Foi utilizado o kit comercial para diagnóstico da dengue Platelia ${ }^{T M}$ dengue NS1 AG (Bio-Rad Laboratories, França), seguindo o protocolo recomendado pelo fabricante. $\mathrm{O}$ valor de cutoff corresponde à média da densidade ótica (DO) da duplicata dos controles de cuttoff do kit. Os resultados das amostras foram expressos como quociente da razão entre a DO da amostra e a média do DO dos cutoff. A amostra foi considerada negativa quando essa razão teve valor menor que 0,5 , duvidosa quando a razão foi $>0,5$ e $<1$, e positiva quando a razão foi $>1$.

O teste Platelia ${ }^{\mathrm{TM}}$ dengue NS1 Ag é um método imunoenzimático em uma fase, de tipo sandwich, em formato microplaca, para detecção qualitativa ou 
semi-quantitativa do antigénio NS1 do vírus da dengue no soro ou plasma humano. O teste utiliza anticorpos monoclonais (AcM) de ratos para a captura e a revelação.

As amostras de doentes e os controles foram incubados, durante 90 minutos a $37^{\circ} \mathrm{C}$, nos poços da microplaca sensibilizada pelos AcM. Em presença do antígeno NS1 na amostra, forma-se um complexo imune AcM - NS1 AcM/peroxidase. Após seis lavagens praticadas no final da incubação, a presença do complexo imune é revelada por adição, em cada poço, de uma solução de revelação enzimática que induz o desenvolvimento de uma reação de coloração. Após 30 minutos de incubação a temperatura ambiente e em ausência total de luz, a reação enzimática foi parada por adição de uma solução de ácido. A densidade óptica obtida a 450/620 nm é proporcional à quantidade de antígeno NS1 presente na amostra testada. A presença do antígeno NS1 numa amostra individual é determinada por comparação da densidade óptica lida nesta amostra e a obtida no soro do valor de calibrador.

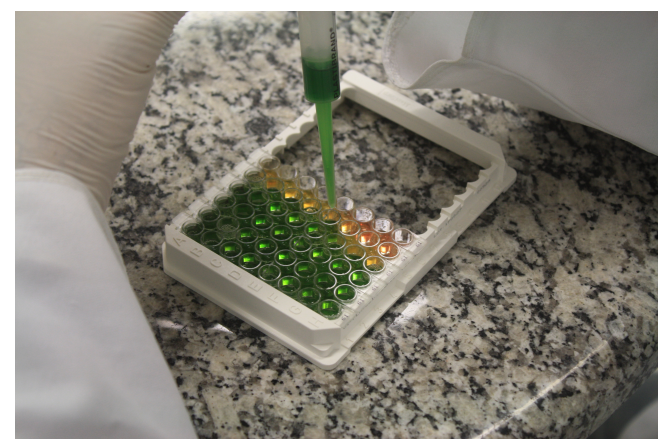

Figura 28 - Processamento das amostras durante o ELISA para NS1.

O teste Platelia ${ }^{\mathrm{TM}}$ dengue NS1 Ag é foi fabricado com o objetivo de ser utilizado para amostras de sangue e, neste estudo, foi utilizado para detectar anticorpos específicos da dengue na saliva, já que não foi encontrado produto específico para esse fim. Os valores para cálculo dos resultados, tempo de incubação e lavagem foram os mesmos utilizados para as amostras de sangue, recomendados pelo fabricante.

Todas amostras foram comparadas com exames de sorologia utilizando anticorpos $\mathrm{lgM} / \mathrm{lgG}$, considerado um dos gold-standards para diagnóstico da dengue. 


\subsection{ANÁLISE ESTATÍSTICA}

Para avaliar os resultados encontrados foram calculados a sensibilidade, especificidade, o valor preditivo positivo, valor preditivo negativo e a prevalência e comparados entre si em tabelas e gráficos.

Razão de probabilidade positiva (RP +): (sensibilidade / (1 especificidade) é um número que representa o quanto um método de resultado positivo influencia a chance de um indivíduo ser doente. Quando mais alto este número, melhor, ou seja: RP +: > 10 (acurácia ótima); 5-10 (acurácia moderada); 2-5 (acurácia pequena); 1-2 (acurácia nula).

Razão de probabilidade negativa (RP -): (1 - sensibilidade / especificidade) representa o quanto um método de resultado negativo influencia a chance de um indivíduo ser saudável. Quanto mais próximo de zero, melhor: RP -: < 0,1 (acurácia ótima); 0,1-0,2 (acurácia moderada); 0,2-0,5 (acurácia pequena); 0,51,0 (acurácia nula) (GALLAGHER, 1998; JAESCHKE; GUYATT; SACKETT, 1994).

Valor preditivo positivo (LR+): é a probabilidade de uma pessoa ser realmente doente se o resultado do exame for positivo.

Valor preditivo negativo (LR -): é a probabilidade de a pessoa ser saudável se o teste for negativo. Desta forma, valor preditivo é uma propriedade do indivíduo submetido ao exame e não do exame em si. Se a probabilidade de doença é muito baixa, qualquer método terá um bom valor preditivo negativo e ruim valor preditivo positivo. Se a probabilidade de doença for muito alta, qualquer método terá ruim valor preditivo negativo e bom valor preditivo positivo (JAESCHKE; GUYATT; SACKETT, 1994) 


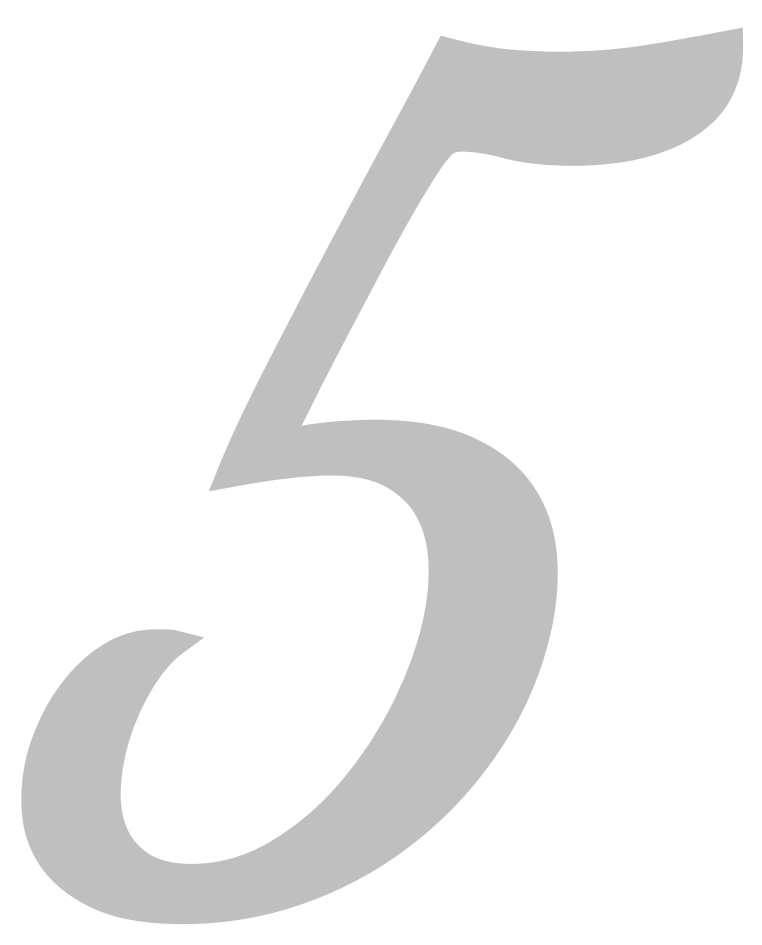

Resultados

"Quanto mais aumenta nosso conhecimento mais evidente fica nossa ignorância." John Kennedy 



\section{RESULTADOS}

\subsection{RESULTADOS PRIMÁRIOS}

\subsubsection{Detecção Dos Sorotipos Virais Utilizando PCR-RT}

O PCR foi realizado em amostras de saliva de dez participantes que apresentavam diagnóstico clínico de sintomas compatíveis com dengue e nos quais as amostras de plasma correspondentes foram de $\mathrm{lgG} / \mathrm{lgM}$ positivo para dengue, no entanto, o RNA de nenhum sorotipo do dengue foi amplificado a partir de nenhuma um destas amostras. Dessa forma, não foi dada continuidade nos exames para as amostras restantes.

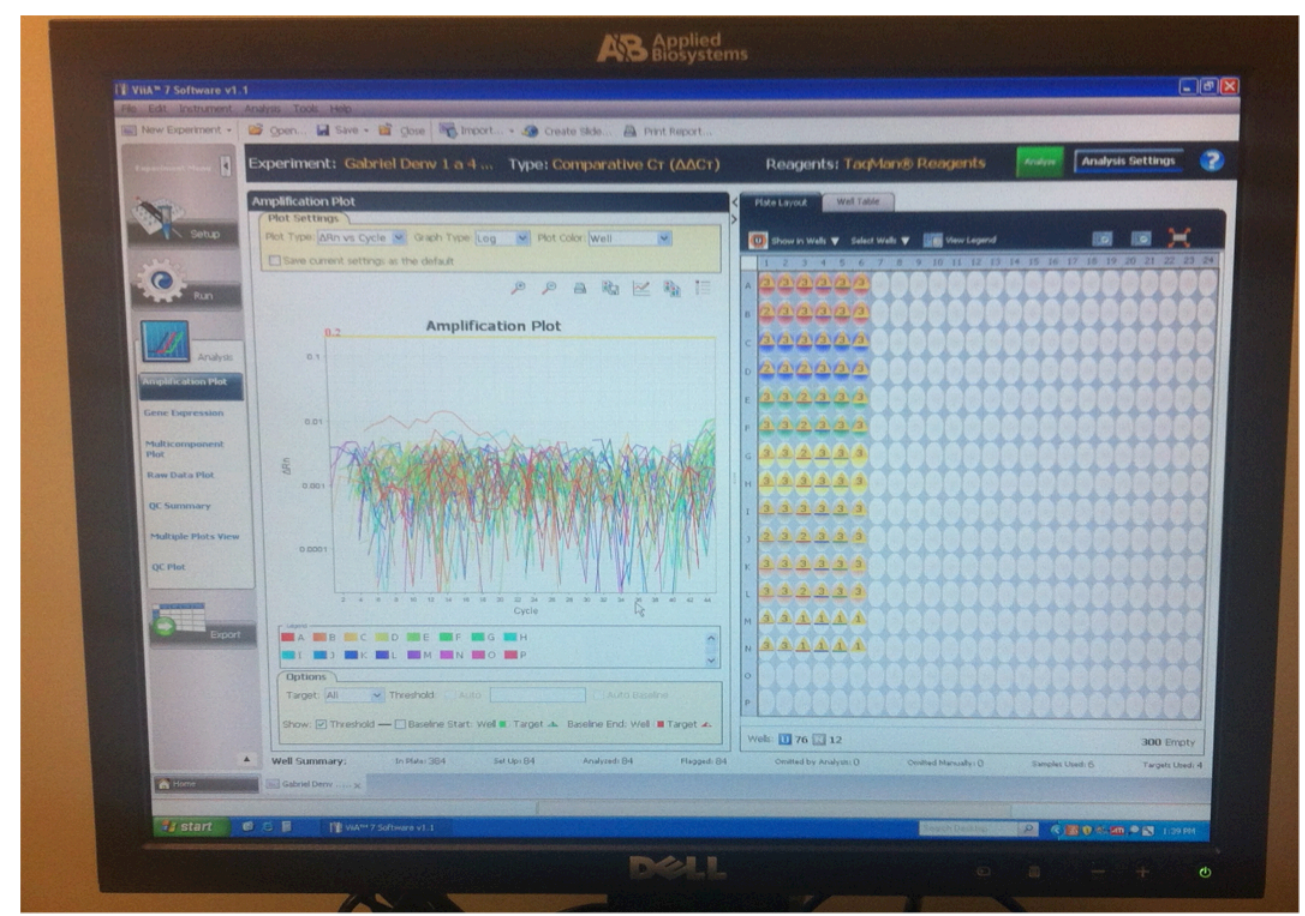

Figura 29 - Imagem da tela de resultado do PCR-RT mostrando que não houve amplificação em nenhuma amostra testada. 


\subsubsection{Detecção da NS1 através do teste imunocromatográfico}

O teste imunocromatográfico foi utilizado em 44 amostras de saliva, destas 28 estavam no período febril da Dengue. Porém não tivemos resultados positivos nem negativos. $O$ teste não funcionou através de amostras de saliva.

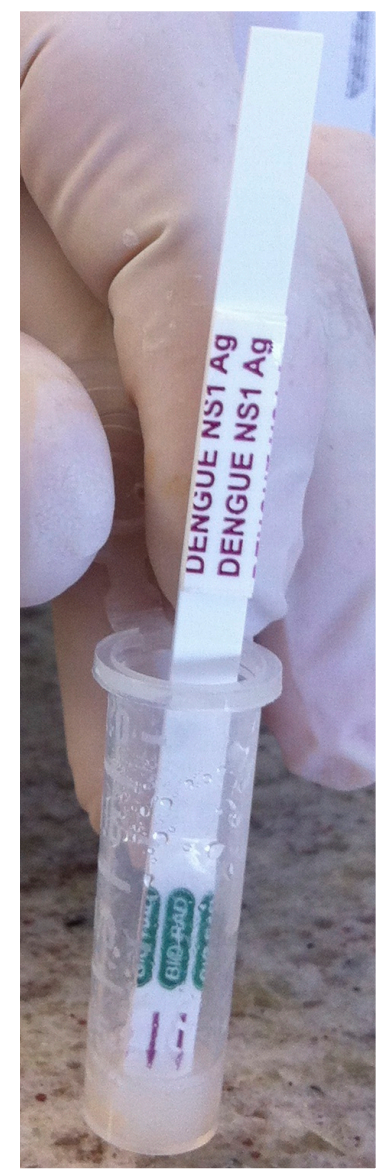

Figura 30 - Imagem mostrando que não há resultado quando é colocada tira em amostras de saliva, nem a linha Teste nem a linha controle ficam pigmentadas.

\subsubsection{Detecção Da NS1 por meio do teste Elisa}

A avaliação da presença do antígeno NS1 foi realizada em 44 amostras de saliva. Todas amostras foram coletadas exclusivamente para esse estudo. As amostras foram consideradas contaminadas ou não de acordo com os resultados da sorologia realizadas no sistema público de saúde.

Para a verificação da presença do NS1 na saliva foi utilizado o Kit Platelia $^{T M}$ dengue NS1 Ag-ELISA, compreendendo amostras positivas e negativas. Uma sensibilidade total de $84 \%$ (24/28) em amostras positivas. Utilizou-se amostras coletadas até o $10^{\circ}$ dia de febre. 
Tabela 8 - Efetividade da identificação da NS1 de acordo com o dia de início da febre.

\begin{tabular}{clll}
\hline \multirow{2}{*}{$\begin{array}{c}\text { Dias de } \\
\text { febre no momento } \\
\text { da coleta }\end{array}$} & Saliva NS1 & Negativo \\
\cline { 2 - 4 } 1 & 1 & - & 1 \\
\cline { 2 - 4 } 2 & 2 & - & 2 \\
3 & 5 & - & 5 \\
4 & 4 & - & 4 \\
5 & 3 & 1 & 4 \\
6 & 5 & - & 5 \\
7 & 4 & - & 4 \\
8 & - & 1 & 1 \\
9 & - & 1 & 1 \\
10 & - & 1 & 1 \\
Total & 24 & 4 & 28 \\
\hline
\end{tabular}

Quando uma pessoa infectada com o vírus da dengue apresenta febre, a infecção está amplamente disseminada. O vírus é encontrado no plasma, no sangue e em alguns tecidos, em fluidos como a saliva, aproximadamente 2 dias antes do início da doença até 5-7 dias depois, período correspondente à fase febril. Durante a fase inicial da doença quando o doente procura o médico (primeiros dias de febre e mal estar), o diagnóstico só é possível por isolamento do vírus, genoma viral ou a detecção do antígeno. No final da fase aguda da infecção geralmente no período da defervescência, a sorologia é o método de escolha para o diagnóstico. Portanto é importante saber a quantos dias do início dos sintomas o teste é mais eficaz.

Tabela 9 - Comparação da efetividade dos diagnósticos durante a epidemia e no período entre as epidemias.

\begin{tabular}{|c|c|c|c|c|c|c|c|c|c|c|c|c|c|}
\hline $\begin{array}{l}\text { Período de } \\
\text { coleta }\end{array}$ & Teste & Amostra & $\mathbf{N}$ & TP & FP & FN & TN & SN & SP & PPV & NPV & LR+ & LR- \\
\hline \multirow[b]{2}{*}{ Epidêmico } & $\begin{array}{l}\text { ELISA } \\
\text { NS1 }\end{array}$ & Saliva & 32 & 12 & 0 & 7 & 13 & 0,63 & 1,00 & 1,00 & 0,65 & - & 0,36 \\
\hline & $\begin{array}{l}\text { NS1 } \\
\text { Rapido } \\
\text { NS1 }\end{array}$ & Soro & 32 & 13 & 0 & 6 & 13 & 0,68 & 1,00 & 1,00 & 0,68 & - & 0,31 \\
\hline Inter- & $\begin{array}{l}\text { ELISA } \\
\text { NS1 }\end{array}$ & Saliva & 12 & 7 & 1 & 0 & 4 & 1,00 & 0,80 & 0,87 & 1,00 & 5,00 & 0,00 \\
\hline epidemico & $\begin{array}{l}\text { Rádido } \\
\text { NS1 }\end{array}$ & Soro & 12 & 6 & 0 & 1 & 5 & 0,85 & 1,00 & 1,00 & 0,83 & - & 0,14 \\
\hline \multirow{2}{*}{ Total } & $\begin{array}{l}\text { ELISA } \\
\text { NS1 }\end{array}$ & Saliva & 44 & 19 & 1 & 7 & 17 & 0,73 & 0,94 & 0,95 & 0,70 & 13,15 & 0,28 \\
\hline & $\begin{array}{l}\text { Rápido } \\
\text { NS1 }\end{array}$ & Soro & 44 & 19 & 0 & 7 & 18 & 0,73 & 1,00 & 1,00 & 0,72 & - & 0,26 \\
\hline
\end{tabular}






$$
\underline{6}
$$




Os exames específicos para o diagnóstico da dengue têm a finalidade de orientar ações de vigilância epidemiológica, uma vez que a conduta terapêutica raramente será alterada em função da confirmação pelo laboratório de uma infecção por dengue. O teste de rotina para diagnóstico sorológico da dengue é o ensaio imunoenzimático de captura de anticorpos IgM, o qual foi utilizado nesse estudo. Esse teste, apesar de apresentar bons resultados, somente detecta a doença tardiamente em sua fase aguda (a partir do quinto dia do início dos sintomas), quando os títulos de anticorpos IgM são evidenciados.

A utilização de kits de diagnóstico imunocromatográfico rápido para a detecção da proteína NS1 no soro pode ser uma importante ferramenta para otimizar os recursos no monitoramento das infecções por dengue. Para a técnica de captura da proteína NS1 observou-se maior positividade nas amostras coletadas até o terceiro dia de doença. Portanto, a recomendação de coleta de amostras até o terceiro dia de doença é imprescindível para o bom desempenho dessa metodologia. Com o passar dos dias desde o início dos sintomas, a sensibilidade das tiras de teste rápido diminuiu, provavelmente como reflexo da redução da carga viral e da proteína NS1. Também em outros estudos foi escassa a presença da proteína NS1 entre o sétimo e o nono dias e inexistente após esse período (ANDERS et al., 2012).

Pacientes com viremia muito baixa podem não apresentar NS1 mensurável, o que poderia explicar os resultados falsos negativos da imunocromatografia (POK et al., 2010). Nos casos mais graves da doença, os testes para diagnóstico são sensíveis. A sensibilidade, portanto, depende da severidade da doença na população estudada, nesse estudo não se encontrou nenhum caso de febre hemorrágica da dengue, portanto resultados mais promissores podem ser encontrados em regiões com prevalência maior de casos graves.

$O$ isolamento viral seguido de imunofluorescência indireta é a técnica considerada referência para deteç̧ão e identificação do DENV. Entretanto, esse procedimento requer instalações apropriadas, apresenta custo elevado e demora cerca de 7 a 10 dias para ser concluído. Além disso, após o terceiro dia do início dos sintomas, o nível de anticorpos começa a subir, interferindo no resultado e na sensibilidade do isolamento (SASAKI et al., 2013). 
Não foi possível identificar e amplificar o RNA em amostras de saliva através da técnica de PCR-RT, essa dificuldade foi também encontrada recentemente em outro estudo (ANDERS et al., 2012). No entanto, não se pode afirmar que as amostras não continham RNA do vírus, uma vez que não foram utilizados controles positivos, ou seja, amostras dos quatro sorotipos do vírus, para que o funcionamento das sondas e dos primers fosse certificado. Por outro lado, as sondas e os primers utilizados, da marca TaqMan ${ }^{\circledR}$ possuem uma grande confiabilidade internacional (CALLAHAN et al., 2001; CHAO; DAVIS; CHANG, 2007; LAUE; EMMERICH; SCHMITZ, 1999). Outro possível viés pode ter sido com relação ao tipo de saliva coletado. Nesse estudo pela primeira vez na literatura, preconizamos a coleta de saliva não estimulada por meio de um dispositivo sugador, diferentemente dos outros estudos que coletam a saliva por meio de dispositivos que promovem a abrasão do epitélio bucal ou a estimulação salivar (ANDERS et al., 2012; MIZUNO et al., 2007; POLONI et al., 2010; TORRES; LIPRANDI; GONCALVEZ, 2000; YAP; SIL; NG, 2011). Devido à alta sensibilidade do RNA, a saliva estagnada talvez não seja capaz de manter o RNA estruturado, sendo que, talvez por esse motivo não seja possível amplificá-lo no PCR-RT. Neste trabalho não foi encontrado o vírus na saliva por PCR-RT na saliva, mas alguns aspectos devem ser levados em consideração, o primeiro que o vírus pode não estar viável ou apresentar apenas fragmentos degradados desse vírus nos testes de PCR-RT. Outra possibilidade, menos provável, seriam os primers da identificação não estarem funcionando. Sugere-se que para trabalhos futuros, controles positivos com todos os sorotipos da dengue sejam utilizados no PCR-RT para confirmação do funcionamento dos primers.

O RNA viral pode não estar viável na saliva devido a ação de enzimas ou pode não ser encontrado em alguns períodos da infecção pode dengue. Porém a presença do vírus no organismo do hospedeiro pode infectar células e, portanto, codificar e liberar proteínas como a proteína não estrutural 1, que é secretada por todo o corpo, inclusive na saliva, como mostrado neste trabalho. Outra possibilidade seriam as NS-1 circularem na saliva oriundas do sangue, dessa forma, o resultado para o exame de PCR-RT na saliva foi negativo enquanto o para NS1 foi positivo.

Com relação ao aspecto financeiro, embora os testes apresentem valores semelhantes, as tiras de diagnóstico rápido (imunocromatográfico) para dengue permitem realizar o exame individual, enquanto que nos testes ELISA e PCR-RT 
ocorre o processamento de várias amostras ao mesmo tempo. Na prática de postos de saúde e hospitais, os laboratórios esperam até que complete-se o número total de amostras que cada teste comporta para somente depois processá-lo, evitando desperdícios. Desse modo, os testes acabam por atrasar as ações de vigilância.

Nesse contexto, uma alternativa significativa aos métodos tradicionais é a imunocromatografia, pois trata-se de uma tecnologia inovadora que concentra a reação antígeno/anticorpo em uma única fase sólida, sendo esta mantida em temperatura ambiente. Possui alta sensibilidade, não exige equipamentos ou treinamento específico para realização do teste, e ainda gera o resultado em poucos minutos (HANG et al., 2009). A utilização desse novo método seria importante para regiões mais carentes de infraestrutura do país, onde não se dispõe de centros especializados de saúde ou laboratórios de análises.

A especificidade depende da prevalência de comorbidades com sintomas similares que geram fatores de confusão no diagnóstico. A possibilidade da presença dessas tendências deve ser considerada quando se analisa os resultados de testes diagnósticos. Por isso, nessa dissertação, o diagnóstico foi aplicado na população que irá efetivamente utilizar o teste. Ou seja, tanto o grupo teste como o grupo controle foram sujeitos que tiveram febre, alguns por dengue e outros por outras infecções. Isso deixa os resultados mais confiáveis do que a utilização de um grupo controle sadio, que na prática clínica não utilizará o teste para o diagnóstico, uma vez que estão sadios.

$\mathrm{Na}$ infecção por dengue, devido ao início da permeabilidade vascular, mudanças sutis podem aparecer. Um diagnóstico precoce para esses casos é a prova do laço. A realização da prova do laço é uma recomendação do Ministério da Saúde e por ser um técnica simples, rápida e barata continua a ser utilizada. Um resultado positivo deve levar a uma observação mais atenta, mas um resultado negativo não exclui que possa existir uma infecção por dengue ou dengue hemorrágica em curso, não existem métodos comprovadamente eficazes para diferenciar precocemente a Dengue Hemorrágica da Dengue Clássica. Petéquias, trombocitopenia e o citado teste do laço positivo durante o exame clínico fracamente diferenciam essas duas entidades clínicas. Nesse estudo não foi possível relacionar os resultados laboratoriais com a Dengue Clássica ou Hemorrágica, já que, por ser um estudo transversal, não foi realizado o acompanhamento dos pacientes e, dessa 
forma não foi possível conseguir informações sobre qual tipo de dengue afetou os indivíduos avaliados.

O exantema é um sinal já descrito como frequente nos casos de dengue (DE FIGUEIREDO et al., 2004). Dentre os sintomas encontrados nos pacientes que participaram desse trabalho, apenas a presença de exantema mostrou ter associação significativa com o diagnóstico laboratorial de dengue, mas, como a presença de exantema está descrita em apenas 1/3 dos casos de dengue, esse seguramente não é um indicador bastante sensível para o diagnóstico dessa virose. O diagnóstico etiológico de um paciente com exantema não é simples, e a epidemiologia é muito importante, cabendo aos profissionais de saúde a atenção adequada para que se possa chegar à conclusão correta dos casos.

Foi interessante o fato de o estudo ser conduzido em dois períodos de diferentes ocorrências de dengue, evidenciando que os critérios do Ministério da Saúde têm maior sensibilidade em época de epidemia, uma demonstração de que o seu valor preditivo aumenta proporcionalmente conforme a frequência da doença.

Nesse trabalho, o teste ELISA Platelia ${ }^{T M}$ Dengue NS1 foi feito com amostras de saliva, porém utilizando-se todas as configurações indicadas para quando o teste é realizado com soro, e mesmo assim os resultados foram muito bons. Talvez se, em uma pesquisa futura utilizar-se configurações diferentes, os resultados sejam melhores. Encontrou-se sugestões de que, devido à menor concentração de anticorpos na saliva, a nova diluição feita deverá ser de 1:25 (95,8\% de diluição da saliva) pois é relatada como a melhor diluição para diferenciar os casos com e sem infecções por dengue. Novos testes devem ser feitos para determinar a diluição quando se tratar de saliva estimulada e não estimulada.

Quando se trata de doenças transmissíveis de grandes proporções, como é o caso da dengue, muitos segmentos como indústrias químicas e farmacêuticas, laboratórios, atendimentos ambulatoriais, hospitais públicos e privados, mídia e recursos humanos estão envolvidos com diferentes interesses no assunto.

Nesta presente casuística, não ocorreu nenhum caso de FHD, diferentemente do que foi encontrado em estudos da Tailândia, Filipinas e Malásia, onde as epidemias ocorrem desde 1954 e existe uma cocirculação viral dos quatros sorotipos de dengue e geralmente as crianças manifestam principalmente as formas graves e não usuais da doença, o que sugere que nossos resultados são aplicáveis em casos menos graves de dengue. 


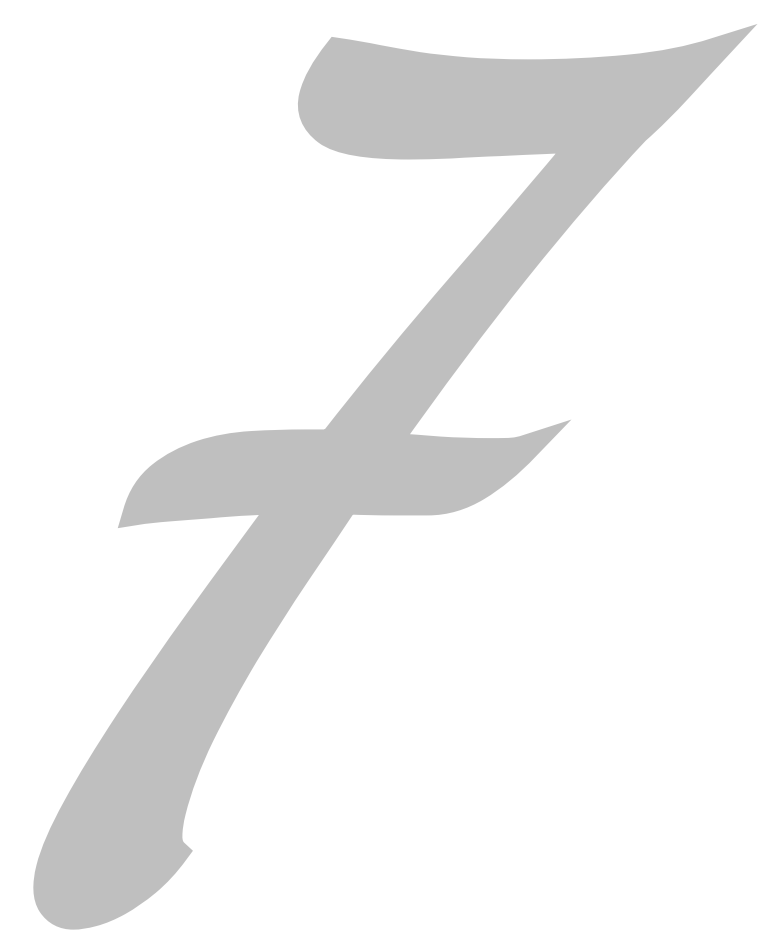

\section{Conclusões}

"Ser o homem mais rico do cemitério não importa para mim... Ir para cama à noite dizendo que fizemos algo maravilhoso... é isso que importa para mim." 



\section{CONCLUSÕES}

Esse estudo ressaltou a importância da busca pelo diagnóstico laboratorial rápido, prático e financeiramente acessível de doenças febris agudas com sintomas inespecíficos, principalmente em áreas de ocorrência de dengue.

Nesse estudo foi encontrada alta especificidade (94\%) e média sensibilidade $(73 \%)$ nos resultados da identificação da proteína não estrutural NS1 nas amostras de saliva dos pacientes infectados com dengue. Esse método, se aprimorado para saliva, poderá ter resultados ainda melhores, por isso mais estudos são necessários.

De acordo com o baixo índice de falso positivos pode-se afirmar que a presença da NS1 na saliva indica um paciente infectado por dengue. Não foi possível identificar o RNA do vírus em amostras de saliva.

Além disso, os resultados mostram associação de alta sensibilidade e média especificidade na identificação da NS1 na saliva em estágios precoces da infecção por dengue. 




\section{Referências}






\section{REFERENCIAS}

Alcon S, Talarmin A, Debruyne M, Falconar A, Deubel V, Flamand M. EnzymeLinked Immunosorbent Assay Specific to Dengue Virus Type 1 Nonstructural Protein Ns1 Reveals Circulation of the Antigen in the Blood During the Acute Phase of Disease in Patients Experiencing Primary or Secondary Infections. J Clin Microbiol. 2002;40(2):376-81.

Alexander Díaz-Quijano F, Aralí Martínez-Vega R, Elvira Ocazionez R, Angel VillarCenteno L. Evaluation of Igm Determination in Acute Serum for the Diagnosis of Dengue in an Endemic Area. Enferm Infecc Microbiol Clin. 2006;24(2):90-2.

Anders KL, Nguyet NM, Quyen NT, Ngoc TV, Tram TV, Gan TT, et al. An Evaluation of Dried Blood Spots and Oral Swabs as Alternative Specimens for the Diagnosis of Dengue and Screening for Past Dengue Virus Exposure. Am J Trop Med Hyg. 2012;87(1):165-70.

Artimos de Oliveira S, Rodrigues CV, Camacho LA, Miagostovich MP, Araujo ES, Nogueira RM. Diagnosis of Dengue Infection by Detecting Specific Immunoglobulin M Antibodies in Saliva Samples. J Virol Methods. 1999;77(1):81-6.

Azevedo Neto RS, Richards A, Nokes DJ, Silveira AS, Cohen BJ, Passos SD, et al. Salivary Antibody Detection in Epidemiological Surveys: A Pilot Study after a Mass Vaccination Campaign against Rubella in Sao Paulo, Brazil. Trans R Soc Trop Med Hyg. 1995;89(1):115-8.

Balmaseda A, Guzman MG, Hammond S, Robleto G, Flores C, Tellez Y, et al. Diagnosis of Dengue Virus Infection by Detection of Specific Immunoglobulin M and Iga Antibodies in Serum and Saliva. Clin Diagn Lab Immunol. 2003;10(2):317-22.

Balmaseda A, Saborio S, Tellez Y, Mercado JC, Perez L, Hammond SN, et al. Evaluation of Immunological Markers in Serum, Filter-Paper Blood Spots, and Saliva for Dengue Diagnosis and Epidemiological Studies. J Clin Virol. 2008;43(3):287-91.

Barkham TM, Chung YK, Tang KF, Ooi EE. The Performance of Rt-Pcr Compared with a Rapid Serological Assay for Acute Dengue Fever in a Diagnostic Laboratory. Trans R Soc Trop Med Hyg. 2006;100(2):142-8.

Bazzichi L, Ciregia F, Giusti L, Baldini C, Giannaccini G, Giacomelli C, et al. Detection of Potential Markers of Primary Fibromyalgia Syndrome in Human Saliva. Proteom Clin Appl. 2009;3(11):1296-30 
Boussemart T, Babe P, Sibille G, Neyret C, Berchel C. Prenatal Transmission of Dengue: Two New Cases. J Perinatol. 2001;21(4):255-7.

Bravo JR, Guzman MG, Kouri GP. Why Dengue Haemorrhagic Fever in Cuba? 1. Individual Risk Factors for Dengue Haemorrhagic Fever/Dengue Shock Syndrome (Dhf/Dss). Trans R Soc Trop Med Hyg. 1987;81(5):816-20.

Bressanelli S, Stiasny K, Allison SL, Stura EA, Duquerroy S, Lescar J, et al. Structure of a Flavivirus Envelope Glycoprotein in Its Low-Ph-Induced Membrane Fusion Conformation. EMBO J. 2004;23(4):728-38.

Brown DW, Ramsay ME, Richards AF, Miller E. Salivary Diagnosis of Measles: A Study of Notified Cases in the United Kingdom. BMJ. 1994;308(6935):1015-7.

Burke DS, Nisalak A, Johnson DE, Scott RM. A Prospective Study of Dengue Infections in Bangkok. Am J Trop Med Hyg. 1988;38(1):172-80.

Callahan JD, Wu SJ, Dion-Schultz A, Mangold BE, Peruski LF, Watts DM, et al. Development and Evaluation of Serotype- and Group-Specific Fluorogenic Reverse Transcriptase Pcr (Taqman) Assays for Dengue Virus. J Clin Microbiol. 2001;39(11):4119-24.

Carey DE. Chikungunya and Dengue: A Case of Mistaken Identity? J Hist Med Allied Sci. 1971;26(3):243-62.

Chakravarti A, Matlani M, Jain M. Immunodiagnosis of Dengue Virus Infection Using Saliva. Curr Microbiol. 2007;55(6):461-4.

Chambers TJ, Hahn CS, Galler R, Rice CM. Flavivirus Genome Organization, Expression, and Replication. Annu Rev Microbiol. 1990;44:649-88.

Chao DY, Davis BS, Chang GJ. Development of Multiplex Real-Time Reverse Transcriptase Pcr Assays for Detecting Eight Medically Important Flaviviruses in Mosquitoes. J Clin Microbiol. 2007;45(2):584-9.

Chaterji S, Allen JC, Chow A, Leo YS, Ooi EE. Evaluation of the Ns1 Rapid Test and the Who Dengue Classification Schemes for Use as Bedside Diagnosis of Acute Dengue Fever in Adults. Am J Trop Med Hyg. 2011;84(2):224-8. 
Chen LH, Wilson ME. Nosocomial Dengue by Mucocutaneous Transmission. Emerg Infect Dis. 2005;11(5):775.

Chen WJ, Hwang KP, Fang AH. Detection of Igm Antibodies from Cerebrospinal Fluid and Sera of Dengue Fever Patients. Southeast Asian J Trop Med Public Health. 1991;22(4):659-63.

Chow L, Hsu ST. Mac-Elisa for the Detection of Igm Antibodies to Dengue Type I Virus (Rapid Diagnosis of Dengue Type I Virus Infection). Zhonghua Min Guo Wei Sheng Wu Ji Mian Yi Xue Za Zhi. 1989;22(4):278-85.

Cordeiro MT, Braga-Neto U, Nogueira RM, Marques ET, Jr. Reliable Classifier to Differentiate Primary and Secondary Acute Dengue Infection Based on Igg Elisa. Plos One. 2009;4(4):4945.

Cuzzubbo AJ, Vaughn DW, Nisalak A, Suntayakorn S, Aaskov J, Devine PL. Detection of Specific Antibodies in Saliva During Dengue Infection. J Clin Microbiol. 1998;36(12):3737-9.

CVE. Distribuição Dos Casos De Dengue Autóctones Segundo O Município Provável De Infecção E Casos Importados De Outros Estados Segundo O Município De Residência No Estado De São Paulo - Ano 2013: Centro de Vigilância Epidemiológica; 2013.

CVE/CCD/SES-SP SDdZ. Distribuição Dos Casos De Dengue Autóctones Segundo O Município Provável De Infecção E Casos Importados De Outros Estados Segundo O Município De Residência No Estado De São Paulo. 2011.

CVE/SES-SP DdZ-. Distribuição Dos Casos De Dengue Autóctones Segundo O Município Provável De Infecção E Casos Importados De Outros Estados Segundo O Município De Residência No Estado De São Paulo, Ano 2010. 2011.

Cunha RV, Maspero RC, Miagostovich MP, de Araujo ES, Luz Dda C, Nogueira RM, et al. Dengue Infection in Paracambi, State of Rio De Janeiro, 1990-1995. Rev Soc Bras Med Trop. 1997;30(5):379-83.

Figueiredo RM, Thatcher BD, de Lima ML, Almeida TC, Alecrim WD, Guerra MV. Exanthematous Diseases and the First Epidemic of Dengue to Occur in Manaus, Amazonas State, Brazil, During 1998-1999. Rev Soc Bras Med Trop. 2004;37(6):476-9. 
DeRoeck D, Deen J, Clemens JD. Policymakers' Views on Dengue Fever/Dengue Haemorrhagic Fever and the Need for Dengue Vaccines in Four Southeast Asian Countries. Vaccine. 2003;22(1):121-9.

DerSimonian R, Laird N. Meta-Analysis in Clinical Trials. Control Clin Trials. 1986;7(3):177-88.

Deville WL, Buntinx F, Bouter LM, Montori VM, de Vet HC, van der Windt DA, et al. Conducting Systematic Reviews of Diagnostic Studies: Didactic Guidelines. BMC Med Res Methodol. 2002;3:2-9.

Doherty R. Australia's Contribution to Tropical Health: Past and Present. Med J Aust. 1993;158(8):552-7.

Dos Santos HW, Poloni TR, Souza KP, Muller VD, Tremeschin F, Nali LC, et al. A Simple One-Step Real-Time Rt-Pcr for Diagnosis of Dengue Virus Infection. J Med Virol. 2008;80(8):1426-33.

Drosten C, Gottig S, Schilling S, Asper M, Panning M, Schmitz H, et al. Rapid Detection and Quantification of Rna of Ebola and Marburg Viruses, Lassa Virus, Crimean-Congo Hemorrhagic Fever Virus, Rift Valley Fever Virus, Dengue Virus, and Yellow Fever Virus by Real-Time Reverse Transcription-Pcr. J Clin Microbiol. 2002;40(7):2323-30.

Dussart P, Labeau B, Lagathu G, Louis P, Nunes MR, Rodrigues SG, et al. Evaluation of an Enzyme Immunoassay for Detection of Dengue Virus Ns1 Antigen in Human Serum. Clin Vaccine Immunol. 2006;13(11):1185-9.

Edelman R. Dengue Vaccines Approach the Finish Line. Clin Infect Dis. 2007;45:5660.

Feldman M, Plancarte A, Sandoval M, Wilson M, Flisser A. Comparison of Two Assays (Eia and Eitb) and Two Samples (Saliva and Serum) for the Diagnosis of Neurocysticercosis. Trans R Soc Trop Med Hyg. 1990;84(4):559-62.

Fernandez-Garcia MD, Mazzon M, Jacobs M, Amara A. Pathogenesis of Flavivirus Infections: Using and Abusing the Host Cell. Cell Host Microbe. 2009;23;5(4):318-28. 
Figueiredo LT. [Viral Hemorrhagic Fevers in Brazil]. Rev Soc Bras Med Trop. 2006;39(2):203-10.

Figueiredo MA, Rodrigues LC, Barreto ML, Lima JW, Costa MC, Morato V, et al. Allergies and Diabetes as Risk Factors for Dengue Hemorrhagic Fever: Results of a Case Control Study. PLoS Negl Trop Dis. 2010;4(6):699.

Frerichs RR, Eskes N, Htoon MT. Validity of Three Assays for Hiv-1 Antibodies in Saliva. J Acquir Immune Defic Syndr. 1994;7(5):522-5.

Friedman MG, Phillip M, Dagan R. Virus-Specific Iga in Serum, Saliva, and Tears of Children with Measles. Clin Exp Immunol. 1989;75(1):58-63.

Gadkari DA, Shaikh BH. Igm Antibody Capture Elisa in the Diagnosis of Japanese Encephalitis, West Nile \& Dengue Virus Infections. Indian J Med Res. 1984;80:613-9.

Gallagher EJ. Clinical Utility of Likelihood Ratios. Ann Emerg Med. 1998;31(3):391-7.

Gubler DJ. Surveillance for Dengue and Dengue Hemorrhagic Fever. Bull Pan Am Health Organ. 1989;23(4):397-404.

Gubler DJ. Dengue and Dengue Hemorrhagic Fever. Clin Microbiol Rev. 1998a;11(3):480-96.

Gubler DJ. The Global Pandemic of Dengue/Dengue Haemorrhagic Fever: Current Status and Prospects for the Future. Ann Acad Med Singapore. 1998;27(2):227-34.

Gubler DJ. The Changing Epidemiology of Yellow Fever and Dengue, 1900 to 2003: Full Circle? Comp Immunol Microbiol Infect Dis. 2004;27(5):319-30.

Guzman MG, Kouri G. Advances in Dengue Diagnosis. Clin Diagn Lab Immunol. 1996;3(6):621-7.

Guzman MG, Kouri G. Dengue: An Update. Lancet Infect Dis. 2002 Jan;2(1):33-42. Halligan S. Systematic Reviews and Meta-Analysis of Diagnostic Tests. Clin Radiol. 2005;60(9):977-9. 
Halstead SB. Observations Related to Pathogensis of Dengue Hemorrhagic Fever. Vi. Hypotheses and Discussion. Yale J Biol Med. 1970;42(5):350-62.

Halstead SB. Pathogenesis of Dengue: Challenges to Molecular Biology. Science. 1988;239(4839):476-81.

Halstead SB. Antibody, Macrophages, Dengue Virus Infection, Shock, and Hemorrhage: A Pathogenetic Cascade. Rev Infect Dis. 1989;11:830-9.

Halstead SB. Dengue. Lancet. 2007;370(9599):1644-52.

Halstead SB, Deen J. The Future of Dengue Vaccines. Lancet. 2002;360(9341):1243-5.

Hang VT, Nguyet NM, Trung DT, Tricou V, Yoksan S, Dung NM, et al. Diagnostic Accuracy of Ns1 Elisa and Lateral Flow Rapid Tests for Dengue Sensitivity, Specificity and Relationship to Viraemia and Antibody Responses. PLoS Negl Trop Dis. 2009;3(1):360.

Hegedus EJ, Cook C, Hasselblad V, Goode A, McCrory DC. Physical Examination Tests for Assessing a Torn Meniscus in the Knee: A Systematic Review with MetaAnalysis. J Orthop Sports Phys Ther. 2007;37(9):541-50.

Holmes EC, Twiddy SS. The Origin, Emergence and Evolutionary Genetics of Dengue Virus. Infect Genet Evol. 2003;3(1):19-28.

Honest $\mathrm{H}$, Khan KS. Reporting of Measures of Accuracy in Systematic Reviews of Diagnostic Literature. BMC Health Serv Res. 2002;2:4.

Houng HS, Chung-Ming Chen R, Vaughn DW, Kanesa-thasan N. Development of a Fluorogenic Rt-Pcr System for Quantitative Identification of Dengue Virus Serotypes 1-4 Using Conserved and Serotype-Specific 3' Noncoding Sequences. J Virol Methods. 2001;95(1-2):19-32.

Hu S, Gao K, Pollard R, Arellano-Garcia M, Zhou H, Zhang L, et al. Preclinical Validation of Salivary Biomarkers for Primary Sjogren's Syndrome. Arthrit Care Res. 2010;62(11):1633-8. 
Hue KD, Tuan TV, Thi HT, Bich CT, Anh HH, Wills BA, et al. Validation of an Internally Controlled One-Step Real-Time Multiplex Rt-Pcr Assay for the Detection and Quantitation of Dengue Virus Rna in Plasma. J Virol Methods. 2011;177(2):16873.

Jaeschke R, Guyatt GH, Sackett DL. Users' Guides to the Medical Literature. lii. How to Use an Article About a Diagnostic Test. B. What Are the Results and Will They Help Me in Caring for My Patients? The Evidence-Based Medicine Working Group. JAMA. 1994;271(9):703-7.

Jessie K, Fong MY, Devi S, Lam SK, Wong KT. Localization of Dengue Virus in Naturally Infected Human Tissues, by Immunohistochemistry and in Situ Hybridization. J Infect Dis. 2004;15;189(8):1411-8.

Johnson BW, Russell BJ, Lanciotti RS. Serotype-Specific Detection of Dengue Viruses in a Fourplex Real-Time Reverse Transcriptase Pcr Assay. J Clin Microbiol. 2005;43(10):4977-83.

Jou YJ, Lin CD, Lai CH, Chen CH, Kao JY, Chen SY, et al. Proteomic Identification of Salivary Transferrin as a Biomarker for Early Detection of Oral Cancer. Anal Chim Acta. 2010;681(1-2):41-8.

Kao CL, King CC, Chao DY, Wu HL, Chang GJ. Laboratory Diagnosis of Dengue Virus Infection: Current and Future Perspectives in Clinical Diagnosis and Public Health. J Microbiol Immunol Infect. 2005;38(1):5-16.

Kittigul L, Meethien N, Sujirarat D, Kittigul C, Vasanavat S. Comparison of Dengue Virus Antigens in Sera and Peripheral Blood Mononuclear Cells from Dengue Infected Patients. Asian Pac J Allergy Immunol. 1997;15(4):187-91.

Kumarasamy V, Chua SK, Hassan Z, Wahab AH, Chem YK, Mohamad M, et al. Evaluating the Sensitivity of a Commercial Dengue Ns1 Antigen-Capture Elisa for Early Diagnosis of Acute Dengue Virus Infection. Singapore Med J. 2007;48(7):66973.

Lai YL, Chung YK, Tan HC, Yap HF, Yap G, Ooi EE, et al. Cost-Effective Real-Time Reverse Transcriptase Pcr (Rt-Pcr) to Screen for Dengue Virus Followed by Rapid Single-Tube Multiplex Rt-Pcr for Serotyping of the Virus. J Clin Microbiol. 2007;45(3):935-41.

Lanciotti RS, Calisher CH, Gubler DJ, Chang GJ, Vorndam AV. Rapid Detection and Typing of Dengue Viruses from Clinical Samples by Using Reverse TranscriptasePolymerase Chain Reaction. J Clin Microbiol. 1992;30(3):545-51. 
Laue T, Emmerich P, Schmitz H. Detection of Dengue Virus Rna in Patients after Primary or Secondary Dengue Infection by Using the Taqman Automated Amplification System. J Clin Microbiol. 1999;37(8):2543-7.

Libraty DH, Young PR, Pickering D, Endy TP, Kalayanarooj S, Green S, et al. High Circulating Levels of the Dengue Virus Nonstructural Protein Ns1 Early in Dengue IIIness Correlate with the Development of Dengue Hemorrhagic Fever. J Infect Dis. 2002;186(8):1165-8.

Lin CW, Liu KT, Huang HD, Chen WJ. Protective Immunity of E. Coli-Synthesized Ns1 Protein of Japanese Encephalitis Virus. Biotechnol Lett. 2008 Feb;30(2):205-14. Lindenbach BD, Rice CM. Molecular Biology of Flaviviruses. Adv Virus Res. 2003;59:23-61.

Liu WT, Lin WT, Tsai CC, Chuang CC, Liao CL, Lin HC, et al. Enhanced Immune Response by Amphotericin B Following Ns1 Protein Prime-Oral Recombinant Salmonella Vaccine Boost Vaccination Protects Mice from Dengue Virus Challenge. Vaccine. 2006;24(31-32):5852-61.

Lolekha R, Chokephaibulkit K, Yoksan S, Vanprapar N, Phongsamart W, Chearskul S. Diagnosis of Dengue Infection Using Various Diagnostic Tests in the Early Stage of Illness. Southeast Asian J Trop Med Public Health. 2004;35(2):391-5.

Lozach PY, Burleigh L, Staropoli I, Navarro-Sanchez E, Harriague J, Virelizier JL, et al. Dendritic Cell-Specific Intercellular Adhesion Molecule 3-Grabbing Non-Integrin (Dc-Sign)-Mediated Enhancement of Dengue Virus Infection Is Independent of DcSign Internalization Signals. J Biol Chem. 2005;280(25):23698-708.

Mackay IM, Arden KE, Nitsche A. Real-Time Pcr in Virology. Nucleic Acids Res. 2002;15;30(6):1292-305.

Mackenzie JM, Jones MK, Young PR. Immunolocalization of the Dengue Virus Nonstructural Glycoprotein Ns1 Suggests a Role in Viral Rna Replication. Virology. 1996;220(1):232-40.

Mackenzie JS, Gubler DJ, Petersen LR. Emerging Flaviviruses: The Spread and Resurgence of Japanese Encephalitis, West Nile and Dengue Viruses. Nat Med. 2004;10(12):98-S109. 
Marovich M, Grouard-Vogel G, Louder M, Eller M, Sun W, Wu SJ, et al. Human Dendritic Cells as Targets of Dengue Virus Infection. J Investig Dermatol Symp Proc. 2001;6(3):219-24.

Martina BE, Koraka P, Osterhaus AD. Dengue Virus Pathogenesis: An Integrated View. Clin Microbiol Rev. 2009;22(4):564-81.

McSherry JA. Some Medical Aspects of the Darien Scheme: Was It Dengue? Scott Med J. 1982;27(2):183-4.

Miagostovich MP, Ramos RG, Nicol AF, Nogueira RM, Cuzzi-Maya T, Oliveira AV, et al. Retrospective Study on Dengue Fatal Cases. Clin Neuropathol. 1997;16(4):204-8.

Mizuno Y, Kotaki A, Harada F, Tajima S, Kurane I, Takasaki T. Confirmation of Dengue Virus Infection by Detection of Dengue Virus Type 1 Genome in Urine and Saliva but Not in Plasma. Trans R Soc Trop Med Hyg. 2007;101(7):738-9.

Monath TP. Dengue: The Risk to Developed and Developing Countries. Proc Natl Acad Sci U S A. 1994;29(7):2395-400.

Mongkolsapaya J, Dejnirattisai W, Xu XN, Vasanawathana S, Tangthawornchaikul N, Chairunsri A, et al. Original Antigenic Sin and Apoptosis in the Pathogenesis of Dengue Hemorrhagic Fever. Nat Med. 2003;9(7):921-7.

Moraes GH, Duarte EC. Reliability of Dengue Mortality Data in Two National Health Information Systems, Brazil, 2000-2005. Cad Saude Publica. 2009;25(11):2354-64.

Murphy BR, Whitehead SS. Immune Response to Dengue Virus and Prospects for a Vaccine. Annu Rev Immunol. 2011;29:587-619.

Niesters HG. Clinical Virology in Real Time. J Clin Virol. 2002;25(3):12.

Nogueira RM, Miagostovich MP, Lampe E, Schatzmayr HG. Isolation of Dengue Virus Type 2 in Rio De Janeiro. Mem Inst Oswaldo Cruz. 1990;85(2):253.

Nogueira RM, Miagostovich MP, Lampe E, Souza RW, Zagne SM, Schatzmayr HG. Dengue Epidemic in the Stage of Rio De Janeiro, Brazil, 1990-1: Co-Circulation of Dengue 1 and Dengue 2 Serotypes. Epidemiol Infect. 1993;111(1):163-70. 
Nogueira RM, Schatzmayr HG, Miagostovich MP, Farias MF, Farias Filho JD.

Virological Study of a Dengue Type 1 Epidemic at Rio De Janeiro. Mem Inst Oswaldo

Cruz. 1988;83(2):219-25.

Oliveira GSSd, Nicodemo AC, Carvalho VCd, Zambrini H, Siqueira AM, Amato VS, et al. Severe Hepatitis and Jaundice During the Evolution of Dengue Virus Infection: Case Report. Rev Soc Bras Med Trop. 2010;43(3):339-41.

Osanai CH, Travassos da Rosa AP, Tang AT, do Amaral RS, Passos AD, Tauil PL. Dengue Outbreak in Boa Vista, Roraima. Preliminary Report. Rev Inst Med Trop Sao Paulo. 1983;25(1):53-4.

Parry JV, Perry KR, Mortimer PP. Sensitive Assays for Viral Antibodies in Saliva: An Alternative to Tests on Serum. Lancet. 1987;2(8550):72-5.

Parry JV, Perry KR, Panday S, Mortimer PP. Diagnosis of Hepatitis a and B by Testing Saliva. J Med Virol. 1989;28(4):255-60.

Peeling RW, Artsob H, Pelegrino JL, Buchy P, Cardosa MJ, Devi S, et al. Evaluation of Diagnostic Tests: Dengue. Nat Rev Microbiol. 2010;8(12):30-8.

Penna ML. [a Challenge for the Public Health System in Brazil: Dengue Control]. Cad Saude Publica. 2003;19(1):305-9.

Philip Samuel P, Tyagi BK. Diagnostic Methods for Detection \& Isolation of Dengue Viruses from Vector Mosquitoes. Indian J Med Res. 2006;123(5):615-28.

Pok KY, Lai YL, Sng J, Ng LC. Evaluation of Nonstructural 1 Antigen Assays for the Diagnosis and Surveillance of Dengue in Singapore. Vector Borne Zoonotic Dis. 2010;10(10):1009-16.

Poloni TR, Oliveira AS, Alfonso HL, Galvao LR, Amarilla AA, Poloni DF, et al. Detection of Dengue Virus in Saliva and Urine by Real Time Rt-Pcr. Virol J. 2010;7:22.

Pontes RJ, Ruffino-Netto A. Dengue in a Urban Locality of Southeastern Brazil: Epidemiological Aspects. Rev Saude Publica. 1994;28(3):218-27. 
Rico-Hesse R. Molecular Evolution and Distribution of Dengue Viruses Type 1 and 2 in Nature. Virology. 1990;174(2):479-93.

Rocco IM, Silveira VR, Maeda AY, Silva SJ, Spenassatto C, Bisordi I, et al. First Isolation of Dengue 4 in the State of Sao Paulo, Brazil, 2011. Rev Inst Med Trop Sao Paulo. 2012;54(1):49-51.

Rodenhuis-Zybert IA, Wilschut J, Smit JM. Dengue Virus Life Cycle: Viral and Host Factors Modulating Infectivity. Cell Mol Life Sci. 2010;67(16):2773-86.

Sabin AB. Research on Dengue During World War li. Am J Trop Med Hyg. 1952;1(1):30-50.

Sacks HS, Reitman D, Pagano D, Kupelnick B. Meta-Analysis: An Update. Mt Sinai J Med. 1996;63(3-4):216-24.

Sakuntabhai A, Turbpaiboon C, Casademont I, Chuansumrit A, Lowhnoo T, KajasteRudnitski A, et al. A Variant in the Cd209 Promoter Is Associated with Severity of Dengue Disease. Nat Genet. 2005;37(5):507-13.

Sang CT, Cuzzubbo AJ, Devine PL. Evaluation of a Commercial Capture EnzymeLinked Immunosorbent Assay for Detection of Immunoglobulin M and G Antibodies Produced During Dengue Infection. Clin Diagn Lab Immunol. 1998;5(1):7-10.

Sang CT, Hoon LS, Cuzzubbo A, Devine P. Clinical Evaluation of a Rapid Immunochromatographic Test for the Diagnosis of Dengue Virus Infection. Clin Diagn Lab Immunol. 1998;5(3):407-9.

Schatzmayr HG, Nogueira RM, Travassos da Rosa AP. An Outbreak of Dengue Virus at Rio De Janeiro--1986. Mem Inst Oswaldo Cruz. 1986;81(2):245-6.

SES/UF, SINAN. Casos De Dengue. Brasil, Grandes Regiões E Unidades Federadas. 1997 a 2009. 2010.

Shepard DS, Suaya JA, Halstead SB, Nathan MB, Gubler DJ, Mahoney RT, et al. Cost-Effectiveness of a Pediatric Dengue Vaccine. Vaccine. 2004;22(9-10):1275-80. 
Shu PY, Chang SF, Kuo YC, Yueh YY, Chien LJ, Sue CL, et al. Development of Group- and Serotype-Specific One-Step Sybr Green I-Based Real-Time Reverse Transcription-Pcr Assay for Dengue Virus. J Clin Microbiol. 2003;41(6):2408-16.

Shu PY, Huang JH. Current Advances in Dengue Diagnosis. Clin Diagn Lab Immunol. 2004;11(4):642-50.

Silva MV, Dias Camargo E, Vaz AJ, Batista L. Immunodiagnosis of Human Leptospirosis Using Saliva. Trans R Soc Trop Med Hyg. 1992;86(5):560-1.

Siqueira WL, Dawes C. The Salivary Proteome: Challenges and Perspectives. Proteomics Clin Appl. 2011;5(11-12):575-9.

Suaya JA, Shepard DS, Siqueira JB, Martelli CT, Lum LC, Tan LH, et al. Cost of Dengue Cases in Eight Countries in the Americas and Asia: A Prospective Study. Am J Trop Med Hyg. 2009;80(5):846-55.

Swartz MK. The Prisma Statement: A Guideline for Systematic Reviews and MetaAnalyses. J Pediatr Health Care. 2011;25(1):1-2.

Talarmin A, Labeau B, Lelarge J, Sarthou JL. Immunoglobulin a-Specific Capture Enzyme-Linked Immunosorbent Assay for Diagnosis of Dengue Fever. J Clin Microbiol. 1998;36(5):1189-92.

Tambyah PA, Koay ES, Poon ML, Lin RV, Ong BK. Dengue Hemorrhagic Fever Transmitted by Blood Transfusion. N Engl J Med. 2008;359(14):1526-7.

Teixeira MG, Costa MaC, Barreto F, Barreto ML. Dengue: Twenty-Five Years since Reemergence in Brazil. Cad Saude Publica. 2009;S1:7-18.

Thaithumyanon P, Thisyakorn U, Deerojnawong J, Innis BL. Dengue Infection Complicated by Severe Hemorrhage and Vertical Transmission in a Parturient Woman. Clin Infect Dis. 1994;18(2):248-9.

Toledo ALAd, Escosteguy CC, Medronho RdA, Andrade FCd. Confiabilidade Do Diagnóstico Final De Dengue Na Epidemia 2001-2002 No Município Do Rio De Janeiro, Brasil. Cad saúde pública. 2006;22(5):933-40. 
Torres JR, Liprandi F, Goncalvez AP. Acute Parotitis Due to Dengue Virus. Clin Infect Dis. 2000;31(5):28-9.

Vaughn DW, Nisalak A, Kalayanarooj S, Solomon T, Dung NM, Cuzzubbo A, et al. Evaluation of a Rapid Immunochromatographic Test for Diagnosis of Dengue Virus Infection. J Clin Microbiol. 1998;36(1):234-8.

Vazeille-Falcoz M, Adhami J, Mousson L, Rodhain F. Aedes Albopictus from Albania: A Potential Vector of Dengue Viruses. J Am Mosq Control Assoc. 1999;15(4):475-8.

Vazquez S, Cabezas S, Perez AB, Pupo M, Ruiz D, Calzada N, et al. Kinetics of Antibodies in Sera, Saliva, and Urine Samples from Adult Patients with Primary or Secondary Dengue 3 Virus Infections. Int J Infect Dis. 2007;11(3):256-62.

Vazquez S, Perez AB, Ruiz D, Rodriguez R, Pupo M, Calzada N, et al. Serological Markers During Dengue 3 Primary and Secondary Infections. J Clin Virol. 2005;33(2):132-7.

Wang E, Ni H, Xu R, Barrett AD, Watowich SJ, Gubler DJ, et al. Evolutionary Relationships of Endemic/Epidemic and Sylvatic Dengue Viruses. J Virol. 2000;74(7):3227-34.

Weaver SC, Reisen WK. Present and Future Arboviral Threats. Antiviral Res. 2010;85(2):328-45.

Westaway EG, Brinton MA, Gaidamovich S, Horzinek MC, Igarashi A, Kaariainen L, et al. Flaviviridae. Intervirology. 1985;24(4):183-92.

Whiting PF, Rutjes AW, Westwood ME, Mallett S, Deeks JJ, Reitsma JB, et al. Quadas-2: A Revised Tool for the Quality Assessment of Diagnostic Accuracy Studies. Ann Intern Med. 2011;155(8):529-36.

WHO. Dengue: Guidelines for Diagnosis, Treatment, Prevention and Control. Geneva: World Health Organization; 2009.

Wilder-Smith A, Ooi EE, Vasudevan SG, Gubler DJ. Update on Dengue:

Epidemiology, Virus Evolution, Antiviral Drugs, and Vaccine Development. Curr Infect Dis Rep. 2010;12(3):157-64. 
Wills BA, Oragui EE, Stephens AC, Daramola OA, Dung NM, Loan HT, et al. Coagulation Abnormalities in Dengue Hemorrhagic Fever: Serial Investigations in 167 Vietnamese Children with Dengue Shock Syndrome. Clin Infect Dis. 2002;35(3):277-85.

Wu SJ, Grouard-Vogel G, Sun W, Mascola JR, Brachtel E, Putvatana R, et al. Human Skin Langerhans Cells Are Targets of Dengue Virus Infection. Nat Med. 2000;6(7):816-20.

Yap G, Sil BK, Ng LC. Use of Saliva for Early Dengue Diagnosis. PLoS Negl Trop Dis. 2011;5(5):1046.

Young PR, Hilditch PA, Bletchly C, Halloran W. An Antigen Capture Enzyme-Linked Immunosorbent Assay Reveals High Levels of the Dengue Virus Protein Ns1 in the Sera of Infected Patients. J Clin Microbiol. 2000;38(3):1053-7.

Zanotto PM, Gould EA, Gao GF, Harvey PH, Holmes EC. Population Dynamics of Flaviviruses Revealed by Molecular Phylogenies. Proc Natl Acad Sci USA. 1996;93(2):548-53.

Zhan L, Zhang LS, Wang L, Zhu L, Zhang H, Suzuki T, et al. in Vivo Micronuclei and Gene Mutation Induced by Den in the Lacz Transgenic Mouse. Wei Sheng Yan Jiu. 2005;34(3):269-71. 